\title{
Yuma Proving Ground GEM-3-E Data Collection
}

Hollis H. “Jay” Bennett, Jr., Tere A. DeMoss, Morris P. Fields,

November 2007

Ricky A. Goodson, Charles D. Hahn, and John Cliff Morgan

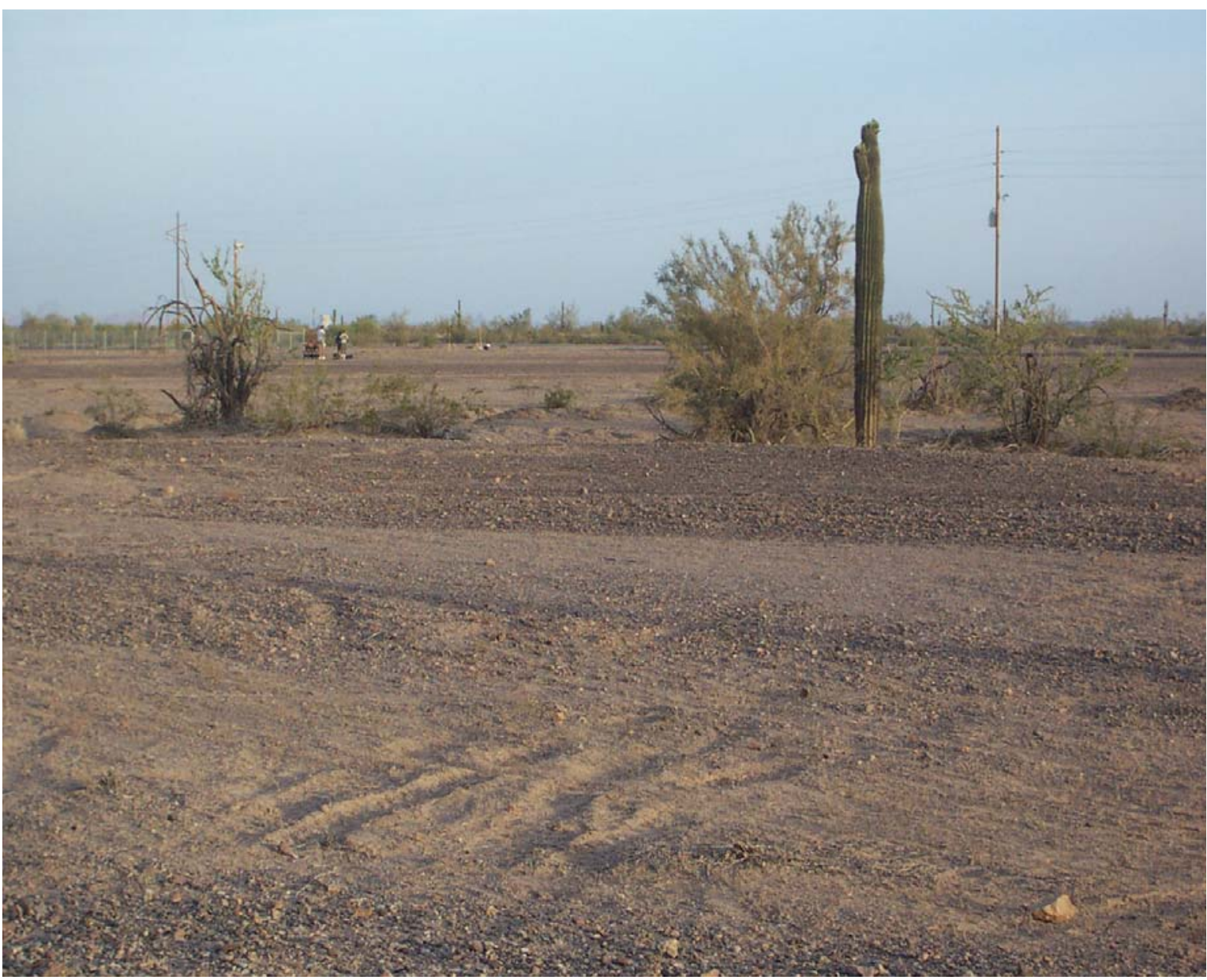




\section{Yuma Proving Ground GEM-3-E Data Collection}

Hollis H. “Jay” Bennett, Jr., Tere A. DeMoss, Morris P. Fields, Ricky A. Goodson, Charles D. Hahn, and John Cliff Morgan

Environmental Laboratory

U.S. Army Engineer Research and Development Center 3909 Halls Ferry Road

Vicksburg, MS 39180-6199

Final report

Approved for public release; distribution is unlimited.

Prepared for U.S. Army Corps of Engineers

Washington, DC 20314-1000

Under Restoration Requirement A (1.6.a), UXO Screening, Detection, and Discrimination 


\begin{abstract}
This report documents the performance and operational capabilities of the GEM-3 system for the Advanced UXO Detection/Discrimination Technology Demonstration at the U.S. Army Yuma Proving Ground (YPG), Yuma, AZ. The data collection effort was conducted under the Department of the Army Research and Development DOBE4 (BA4) Technical Demonstration Program. Data analysis was conducted under the Department of the Army Research and Development DOE3 (BA3) Program. The objective was to evaluate the enhancements made to the GEM-3 system. Post-demonstration analysis focused on the functionality of the sensor system, the evaluation of the noise level of the data collected, improvements in target detection and discrimination, and positioning accuracy of the system. The stability of the system was evaluated through histograms and statistical analysis of data collected during the technology demonstration. Based on findings of the characteristics of the collected data and initial work performed on target detection and discrimination, target detection and discrimination techniques were applied and evaluated.
\end{abstract}

DISCLAIMER: The contents of this report are not to be used for advertising, publication, or promotional purposes. Citation of trade names does not constitute an official endorsement or approval of the use of such commercial products. All product names and trademarks cited are the property of their respective owners. The findings of this report are not to be construed as an official Department of the Army position unless so designated by other authorized documents. 


\section{Contents}

Figures and Tables........................................................................................................................

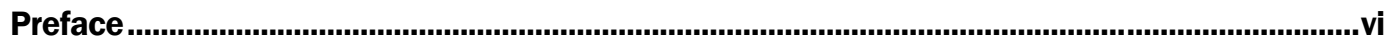

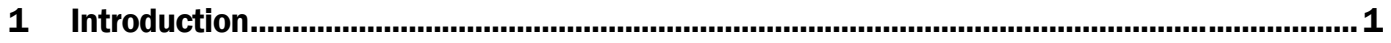

Standardized UXO technology demonstration site ......................................................... 1

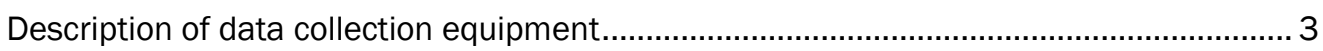

2 Standardized UXO Technology Demonstration Site ....................................................... 5

Areas and grids of the standardized UXO technology demonstration site ........................... 5

Weather conditions ....................................................................................................... 7

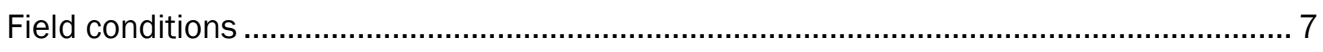

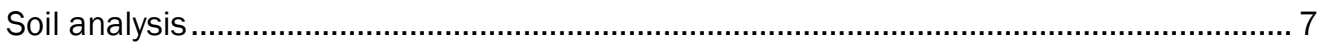

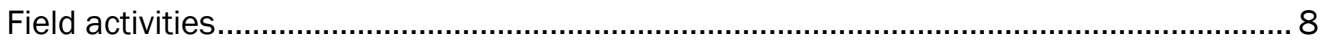

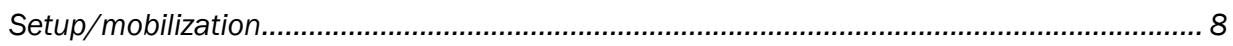

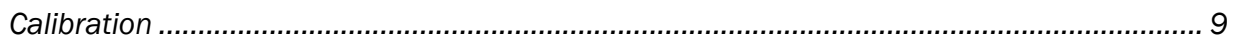

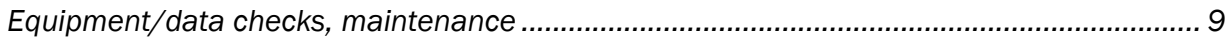

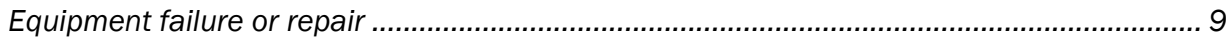

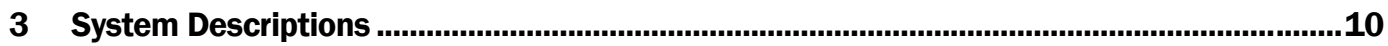

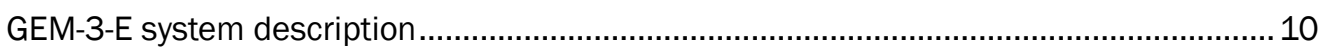

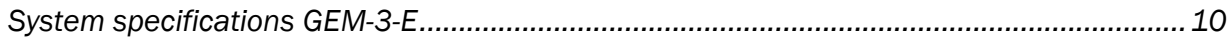

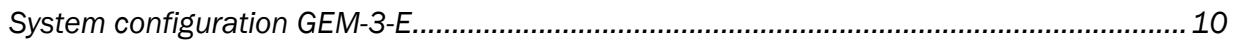

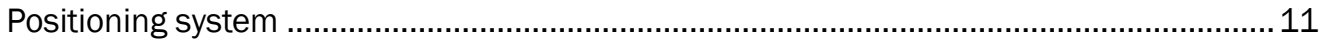

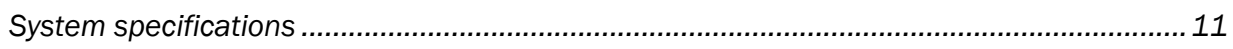

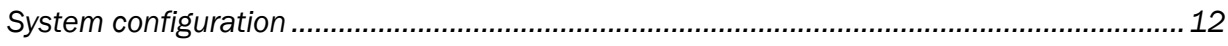

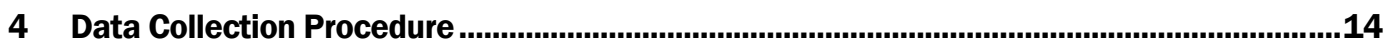

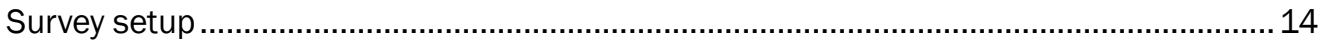

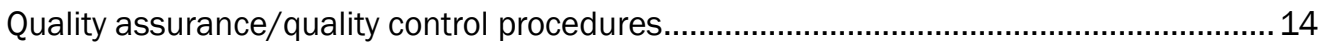

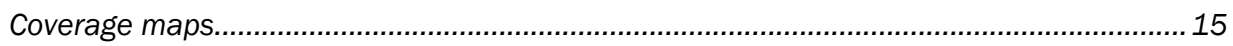

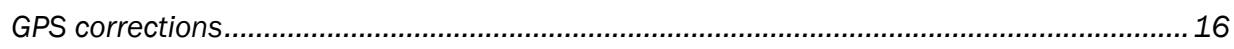

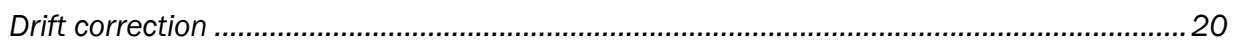

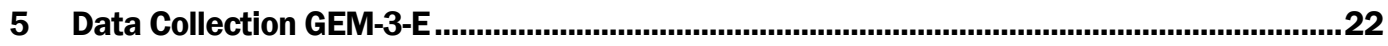

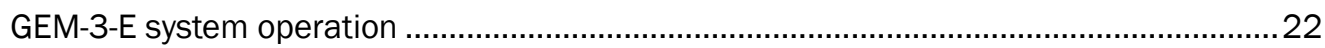

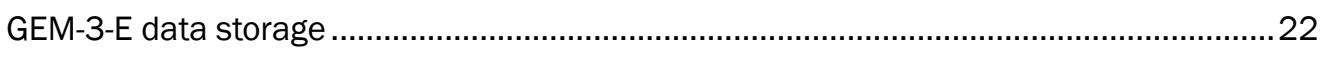

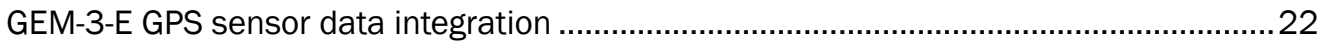

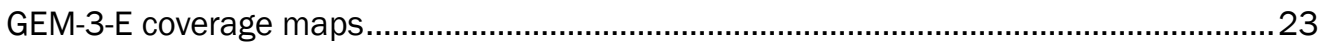

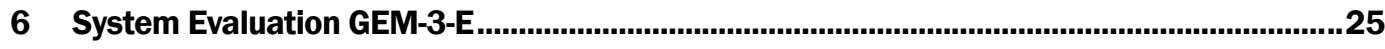

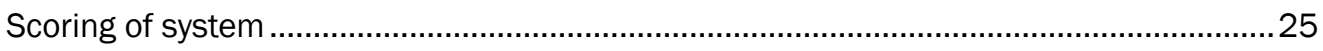

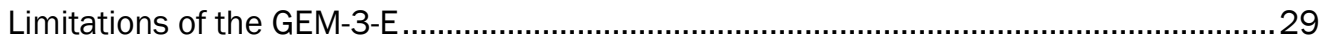




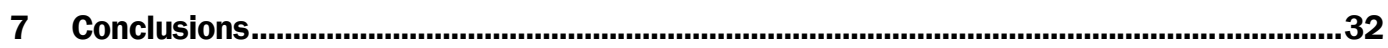

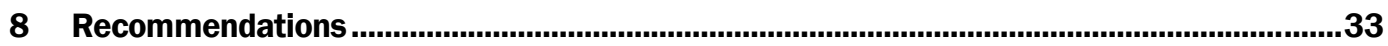

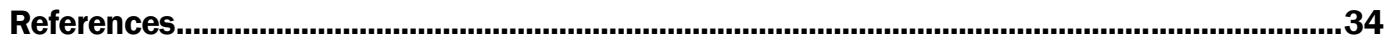

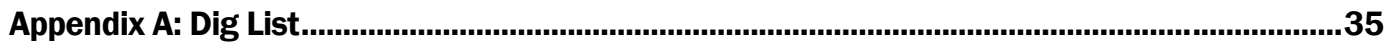

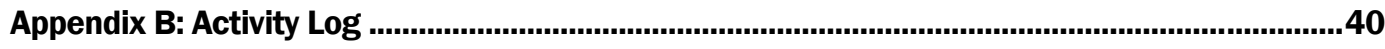

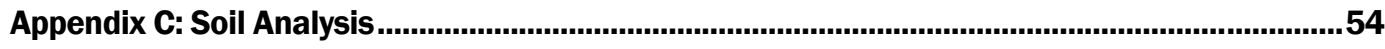

Appendix D: Definitions from ATC Web site .............................................................................56

Report Documentation Page 


\section{Figures and Tables}

\section{Figures}

Figure 1. Photo of standardized UXO technology demonstration site................................................. 2

Figure 2. Overlay map of standardized UXO technology demonstration site. ..................................... 2

Figure 3. Schematic diagram showing internal construction (three concentric coils) of the

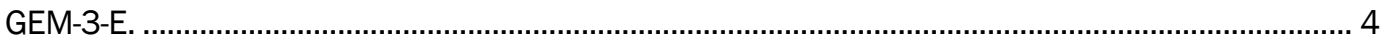

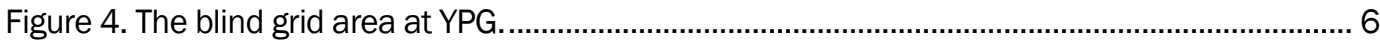

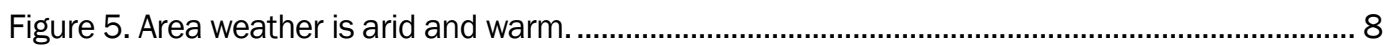

Figure 6. The GEM-3-E cart system with controller and GPS. ........................................................ 11

Figure 7. The GEM-3-E with ropes marking survey grid lines. ........................................................ 15

Figure 8. The calibration pit site configuration............................................................................ 17

Figure 9. The calibration pit located next to calibration lanes. ......................................................... 17

Figure 10. Idealized uncorrected GEM-3-E sensor speed and sensor response versus

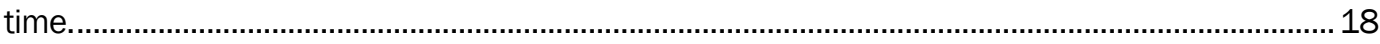

Figure 11. Idealized corrected GEM-3-E sensor speed and sensor response versus time. ..............19

Figure 12. GEM-3-E raw data for the passes over an anomaly before lag correction.......................20

Figure 13. GEM-3-E data for the passes over an anomaly after lag correction. ................................2 20

Figure 14. GEM-3-E (330 Hz) drift corrected (green) and uncorrected (red) signal levels................ 21

Figure 15. GEM-3-E site traverses. ............................................................................................. 23

Figure 16. GEM-3-E coverage map using 0.5-m grid spacing...................................................... 24

Figure 17. GEM-3-E coverage map using 0.75-m grid spacing ........................................................ 24

Figure 18. Standard inert ordnance targets........................................................................... 2 .

\section{Tables}

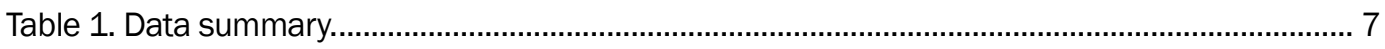

Table 2. Enhanced GEM-3/pushcart - blind grid results (USAEC 2005a) ....................................... 27

Table 3. Enhanced GEM-3/pushcart - open field results (USAEC 2005b)....................................... 28

Table 4. Enhanced GEM-3/pushcart - moguls results (USAEC 2005c)..........................................2.

Table 5. Enhanced GEM-3/pushcart - desert extreme results (USAEC 2005d)............................... 29

Table 6. Analysis of 8-pound shot at depth $=0.2 \mathrm{ft}$......................................................................30

Table C1. Laboratory tests performed on soil samples............................................................... 54

Table C2. Summary of sieve and hydrometer analysis, surface samples. ......................................55 


\section{Preface}

This report describes the efforts conducted under the sponsorship of the Environmental Quality Technology (EQT) Program A (1.6.a), Unexploded Ordnance (UXO) Screening, Detection, and Discrimination Management Plan, Test and Evaluation (BA4), Major Thrust Area II, UXO Technology Demonstration, Work Unit "Hand Held UXO Detector, Design, Demonstration and Validation." The work documented in this report was performed during the period 6- 24 May 2003. This project was funded through the EQT Program. Dr. M. J ohn Cullinane, J r., was Technical Director, Military Environmental Engineering and Science, Environmental Laboratory (EL), U.S. Army Engineer Research and Development Center (ERDC), for EQT UXO work.

J ohn H. Ballard, EL, ERDC, and George Robitaille, U.S. Army Environmental Center (USAEC), were program managers for EQT UXO BA2/3 and BAA programs, respectively. Hollis "J ay" Bennett, Jr., ERDC, EL, was Principal Investigator and was responsible for planning, participated in the execution of field demonstration activities, and directed the analysis of the results. Ricky A. Goodson, Charles D. Hahn, Morris P. Fields, and J ohn Cliff Morgan, ERDC, EL, executed the field demonstrations. Fields was responsible for the daily log records. Bennett, Fields, Goodson, Morgan, and Tere A. DeMoss, EL, and R. Eddie Milton, JAYA, assisted with data analysis. The review and recommendations provided by Aberdeen Test Center (ATC) located at Aberdeen Proving Ground (APG) are gratefully acknowledged.

This project was performed under the general supervision of Dr. David J . Tazik, Chief, Ecosystems Evaluation and Engineering Division, EL, and Dr. Beth C. Fleming, Director, EL.

COL Richard B. J enkins was Commander and Executive Director of ERDC. Dr. J ames R. Houston was Director. 


\section{Introduction}

This report documents the performance and operational capabilities of the GEM-3 system for the Advanced UXO Detection/ Discrimination Technology Demonstration at the U.S. Army Yuma Proving Ground (YPG), Yuma, AZ. The data collection effort was conducted under the Department of Army Research and Development DOBE4 (BA4) Technical

Demonstration Program. Data analysis was conducted under the Department of Army Research and Development DOE3 (BA3) Program. This project addressed the Environmental Quality Technology (EQT) Program thrust area entitled "UXO Technology Demonstration," Work Unit “UXO Detection Design Demonstration and Validation." The work described herein was conducted under Task 1 of this work unit. The objective was to evaluate the enhancements made to the GEM-3 system. Post-demonstration analysis focused on the functionality of the sensor system, the evaluation of the noise level of the data collected, improvements in target detection and discrimination, and positioning accuracy of the system. The stability of the system was evaluated through histograms and statistical analysis of data collected during the technology demonstration. Based on findings of the characteristics of the collected data (Cespedes 2001, ERDC 2002) and initial work performed on target detection and discrimination (Miller et al. 2001), target detection and discrimination techniques were applied and evaluated.

\section{Standardized UXO technology demonstration site}

The YPG standardized UXO technology demonstration site is located within a secured range area of YPG (see Figure 1). YPG is located adjacent to the Colorado River in the Sonoran Desert, about 29 miles from Yuma. The Standardized UXO Technology Demonstration Site is located south of Pole Line Road, and east of the countermine testing and training range (see Figure 2). The open field range, calibration grid, blind test grid, mogul area, and desert extreme area comprise the 350 by $500 \mathrm{~m}$ general test site area. The open field site is the largest of the test sites and measures approximately 200 by $350 \mathrm{~m}$. To the east of the open field range are the calibration lanes and blind test grids (BTG) that measure 30 by $40 \mathrm{~m}$ and 40 by $40 \mathrm{~m}$, respectively. South of the open field is the 135 by $80 \mathrm{~m}$ mogul area consisting of a sequence of man-made depressions. The desert extreme area is located southeast of the open field site and is 50 by $100 \mathrm{~m}$. 


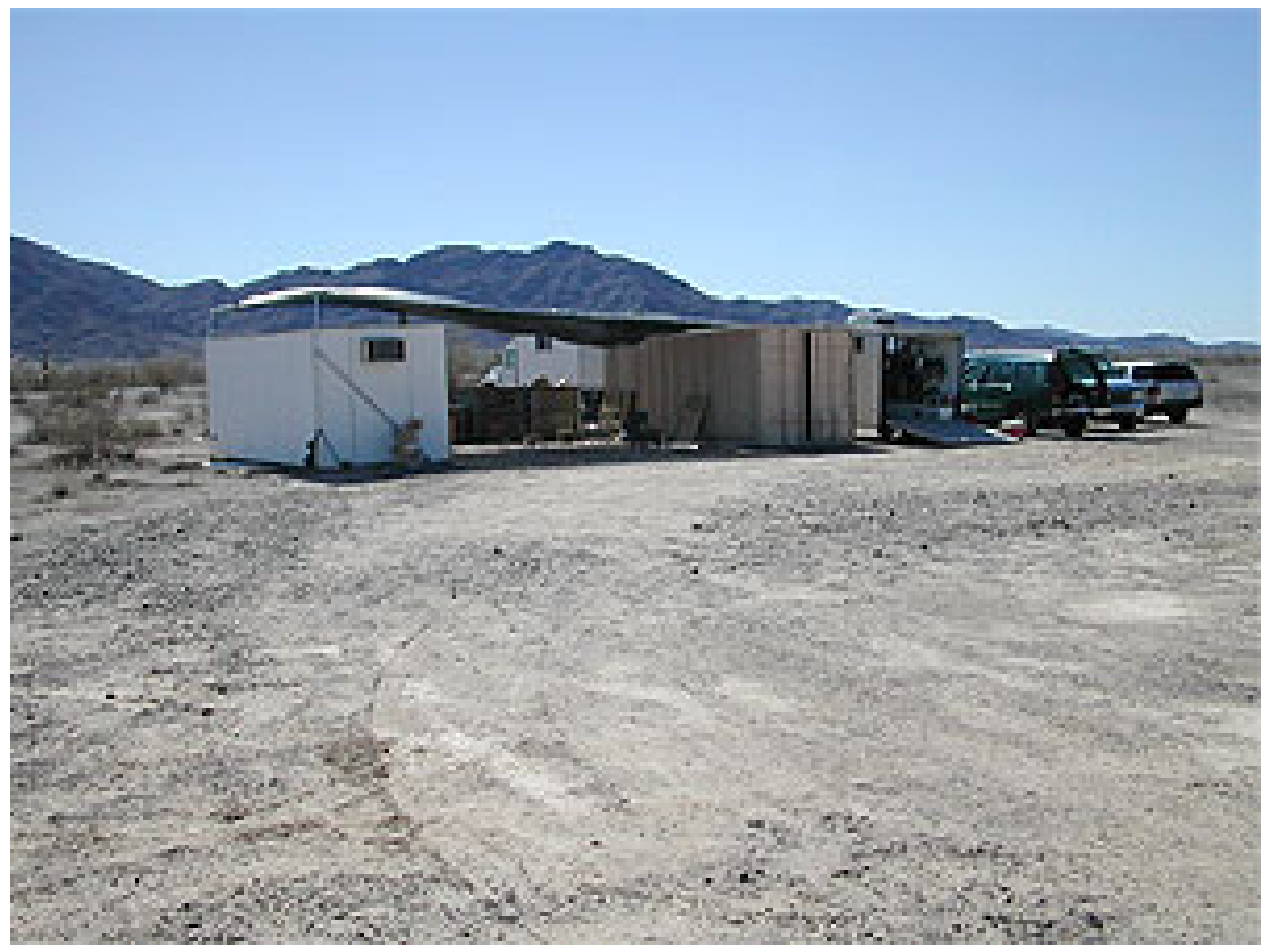

Figure 1. Photo of standardized UXO technology demonstration site.

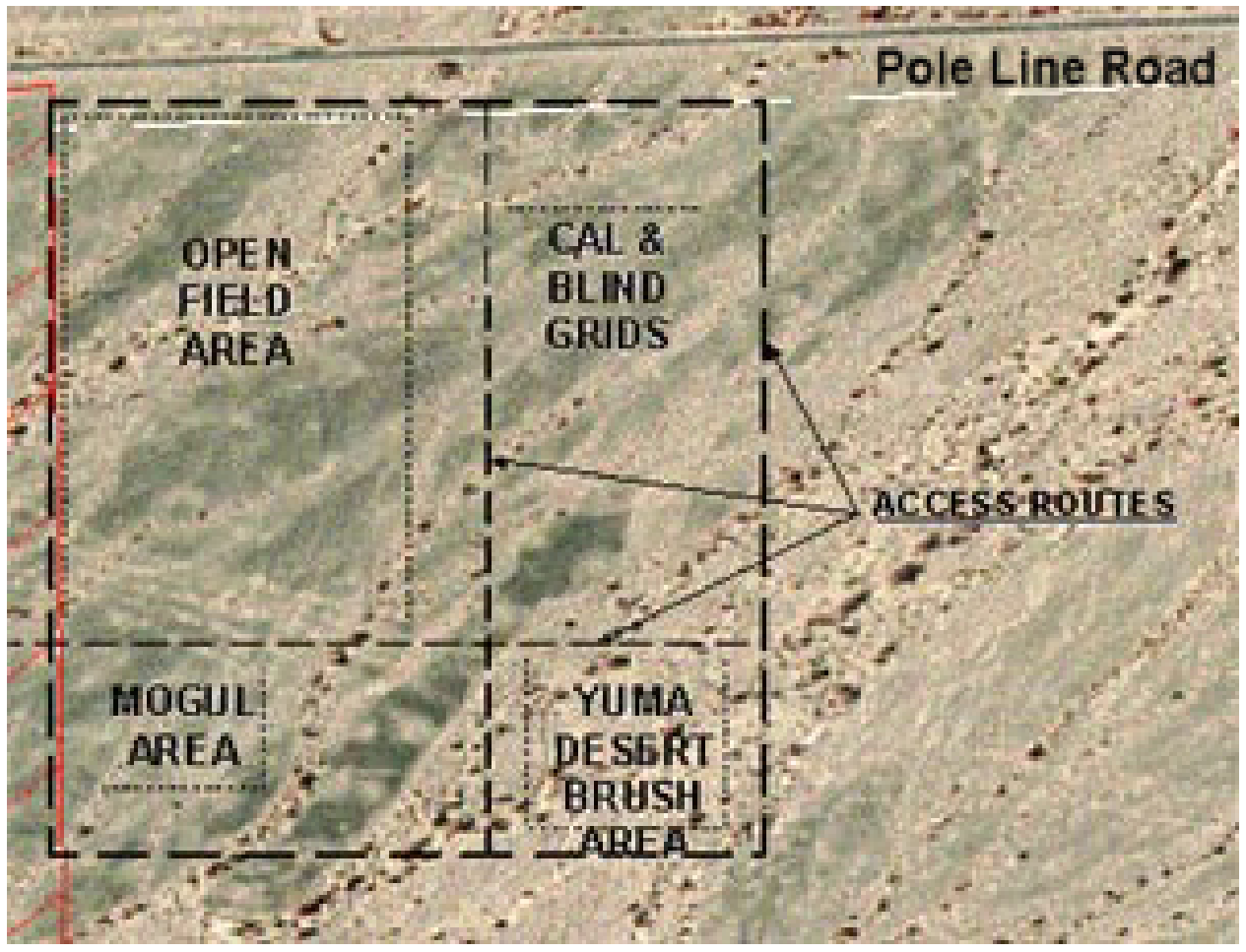

Figure 2. Overlay map of standardized UXO technology demonstration site. 
The desert extreme area, covered with desert-type vegetation, is used to test the performance of different sensor platforms in a more severe desert condition/ environment. The layout description includes the following:

1. Blind test grid - 0.17 hectare $(0.43$ acre $)$

2. Calibration lanes - 0.11 hectare $(0.27$ acre $)$

3. Open field - 6.22 hectares ( 15.38 acres)

4. Scenario 1. Moguls - 1.07 hectares (2.64 acres)

5. Scenario 2. Desert Extreme - 0.50 hectare (1.23 acres).

\section{Description of data collection equipment}

The GEM-3-E, manufactured by Geophex, Ltd., is a multi-frequency frequency domain electromagnetic (FDEM) system (Won et al. 1997). The GEM-3 sensor head contains three concentric coils. The outer coil (TX) is used as a transmitter, an inner low power transmitting coil is a bucking coil (BX) that is used to create a null area, and the innermost coil, located in the null area, is used as a receiver coil (RX) (see Figure 3). The null area allows induced radiation returning from the target to be measured by the $\mathrm{RX}$ coil. Hence, the two transmit coils create a central magnetic cavity producing zero output to the inner receiver coil. For frequency-domain operation, the GEM-3 prompts for a set of desired transmitter frequencies. Built-in software converts this into a digital "bit-stream," which is used to construct the desired transmitter waveform. This bit-stream represents the instruction on how to generate a complex waveform that contains all frequencies specified by the operator. The basic GEM-3 Package consists of a 96-cm-diameter sensing head, handle boom, console with display unit, battery, and a battery charger. Standard data acquisition software includes WinGEMv3, a Windows-based operation software which allows the operator to control the instrument, merge the global positioning system (GPS) stream into the data, and store the data. 


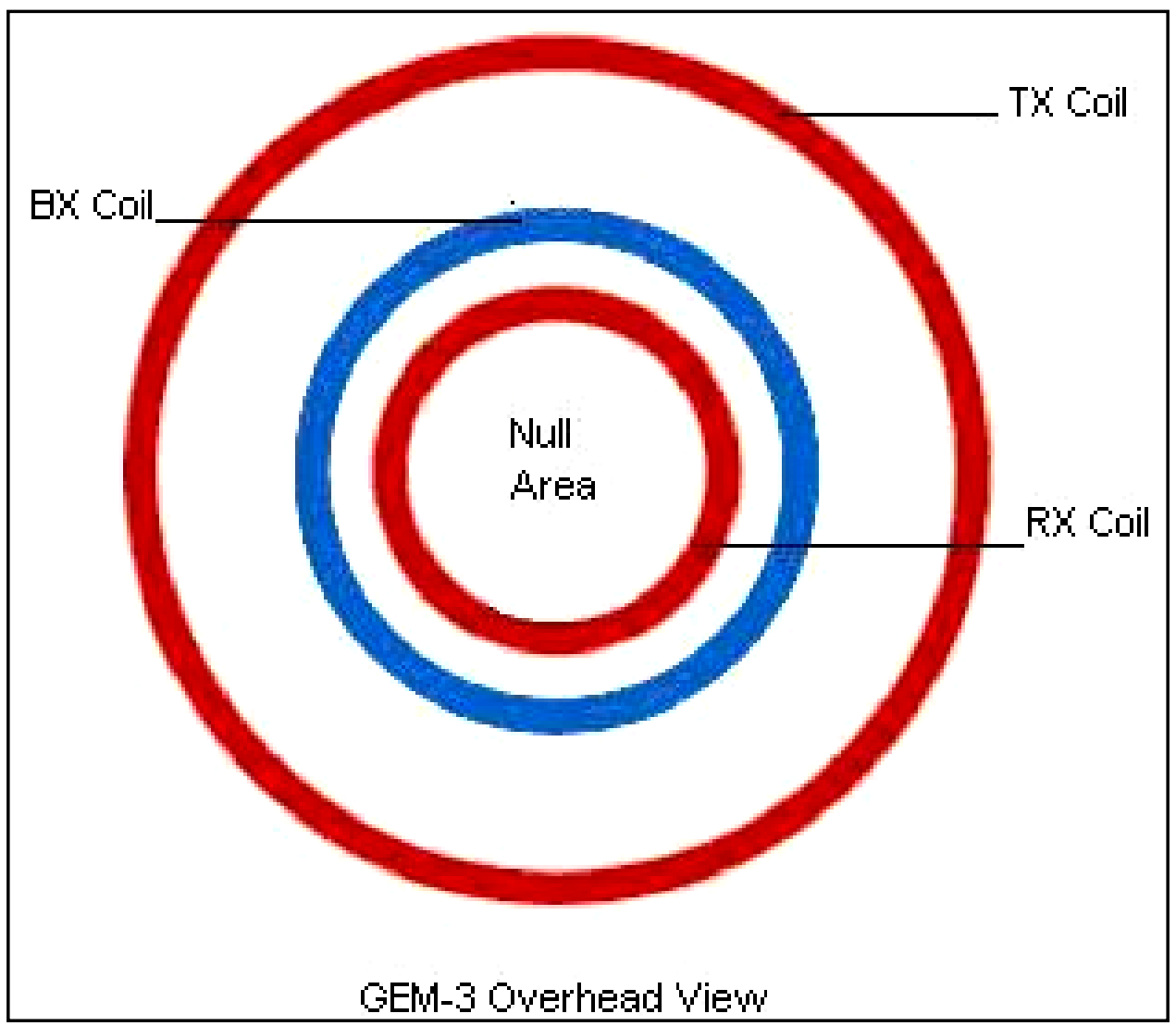

Figure 3. Schematic diagram showing internal construction (three concentric coils) of the GEM-3-E. 


\section{Standardized UXO Technology Demonstration Site}

\section{Areas and grids of the standardized UXO technology demonstration site}

The calibration portion of the test site consisted of 19 lanes. Seventeen of these lanes contained six identical munitions buried in various orientations and at three different depths. One lane contained four steel spheres, 8-lb shotput (8-lb Shot) buried at a depth of 0.5 to $2 \mathrm{~m}$. Another lane contained two each (30.48- and 60.96-cm diameter) circular steel plates buried at 30.48 and $91.44 \mathrm{~cm}$, respectively. A third lane contained 15- and 30-cm diameter copper wire loops (12, 16, 18, and 20 gauge) buried at $0.3 \mathrm{~m}$ depth. These wire loops, which give a standard signature, were used to calibrate the detection signatures received by the instrument. Munitions that are generally rectangular in shape (aspect ratio not equal to one) were buried in the ground in six orientations and at three different depths. Munitions that are generally round in shape (aspect ratio of one) were buried at three different depths. A 3.6-kg steel ball (diameter is $8.9 \mathrm{~cm}$ ) was buried at a depth of $15 \mathrm{~cm}$ at the end of the calibration lanes to provide a uniform signature that could be easily identified when examining the raw data.

The YPG BTG, as shown in Figure 4, consists of a 1,600- $\mathrm{m}^{2}$ area that is located east of the open field range. The BTG was composed of the same type of munitions found in the calibration lanes and open field site. Clutter items included intentionally buried non-UXO targets such as metal, scrap, wood, and rocks.

The open field test area is the largest test area at the YPG Standardized UXO Technology Demonstration Site and measures approximately 200 by $350 \mathrm{~m}$ ( 15.38 acres). The area proved beneficial in providing a variety of realistic scenarios for evaluating sensor system performance of the GEM-3-E. The main challenges include open areas, dips, ruts, electrical lines, metallic fencing, desert extreme, stone pads, and roadway areas. There are virtually thousands of grid cells within the open field area, and at the center of each grid cell there is either ordnance, range clutter, or nothing at all. 


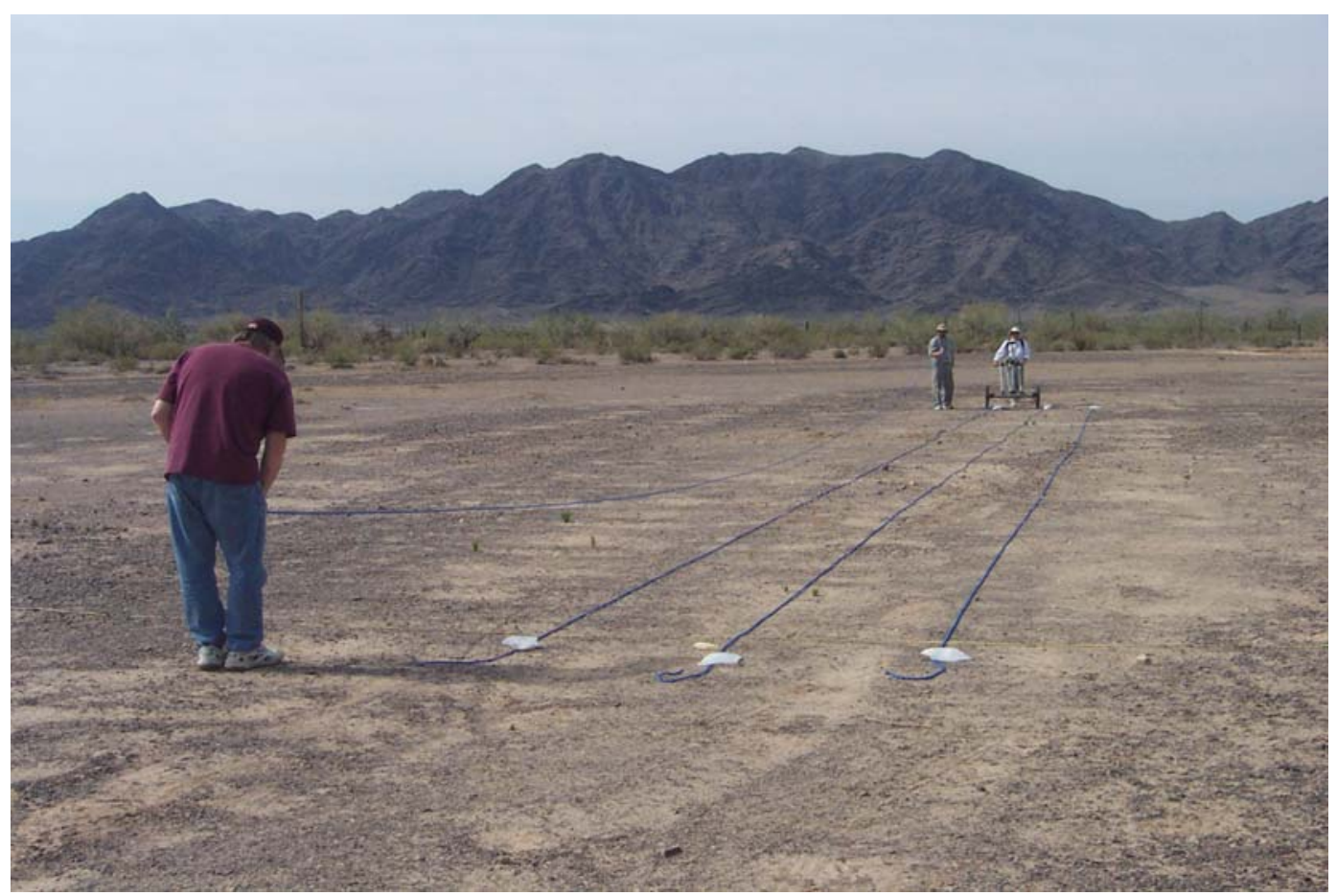

Figure 4. The blind grid area at YPG.

The mogul area (see Figure 2) consisted of two areas: (1) the rectangular or driving portion of the course and (2) the triangular section with more difficult, non-drivable terrain. The rectangular section included six test lanes, which incorporate a slope challenge, $0.61-\mathrm{m}$ and $0.91-\mathrm{m}$ moguls, 0.61-m and 0.91-m slanted moguls, and vibration lanes. This section of the course challenged the GEM-3-E cart's ability to traverse adverse terrain. It was also used to check accuracy of sensor equipment when subjected to vibration and offset angles that resulted from rough terrain. The triangular section incorporated more intense moguls and terrain, which can only be traversed by hand-held or man-portable cart-mounted sensor devices. A series of craters (as deep as $0.91 \mathrm{~m}$ ) and mounds (as high as $0.91 \mathrm{~m}$ ) encompassed this section.

The desert extreme portion of the test site consists of a 50 by $100 \mathrm{~m}$ area that is located southeast of the open field test site (see Figure 2). The area, covered with desert vegetation, was used to evaluate the performance of the GEM-3-E's sensor platform in a more severe desert environment. The soils in this region generally consist of calcium carbonate materials that tend to cement together in the soil, producing hard layers in the subsurface. Ground temperature in this region reached up to $160{ }^{\circ} \mathrm{F}$ in early afternoon. Air temperatures in shaded areas often exceeded $110^{\circ} \mathrm{F}$. 


\section{Weather conditions}

The YPG area year-round records show that on average, Yuma receives approximately 4,133 $\mathrm{hr}$ (93\% of annual $\mathrm{hr}$ ) of sunshine annually. Yuma is in a desert environment, and temperatures generally average above $100{ }^{\circ} \mathrm{F}$ for the summer months. In the extreme desert region, ground temperature can reach up to $160^{\circ} \mathrm{F}$ by early afternoon. However, dry air (low relative humidity) tends to make the days feel cooler and more comfortable than comparable temperate areas with higher relative humidity. During evening hours, evaporative cooling dramatically reduces the temperature.

Table 1. Data summary.

\begin{tabular}{|l|l|}
\hline Average precipitation (inches per year) & 3.43 \\
\hline Monthly average temperature & $75.2{ }^{\circ} \mathrm{F}\left(24^{\circ} \mathrm{C}\right)$ \\
\hline Relative humidity - 11 a.m., July & $32 \%$ \\
\hline Elevation above sea level (feet) & 138 \\
\hline
\end{tabular}

\section{Field conditions}

Personnel of the ERDC surveyed the BTG on 10 May 2003. The weather condition during the data collection for the first week was cloudy and cool in the morning. For the last two weeks of the study (17-31 May), the conditions at YPG were hot and sunny with temperatures reaching $110{ }^{\circ} \mathrm{F}$. A lack of precipitation in this area produced extremely dry field conditions (Figure 5). Gusting winds made data collection and marking of the survey grid with nylon lines very difficult during the first week (10-16 May).

\section{Soil analysis}

Soil samples were collected at the YPG Standardized UXO Test Site to characterize the shallow subsurface $(<3 \mathrm{~m})$ (see Appendix C). Both surface grab samples (15) and continuous soil borings (13) were acquired. Soil laboratory analyses included sieve/ hydrometer, water content, magnetic susceptibility, dielectric permittivity, $x$-ray diffraction, and visual description. Tables with Aberdeen Test Center (ATC) laboratory soil test results are provided in Appendix C. 


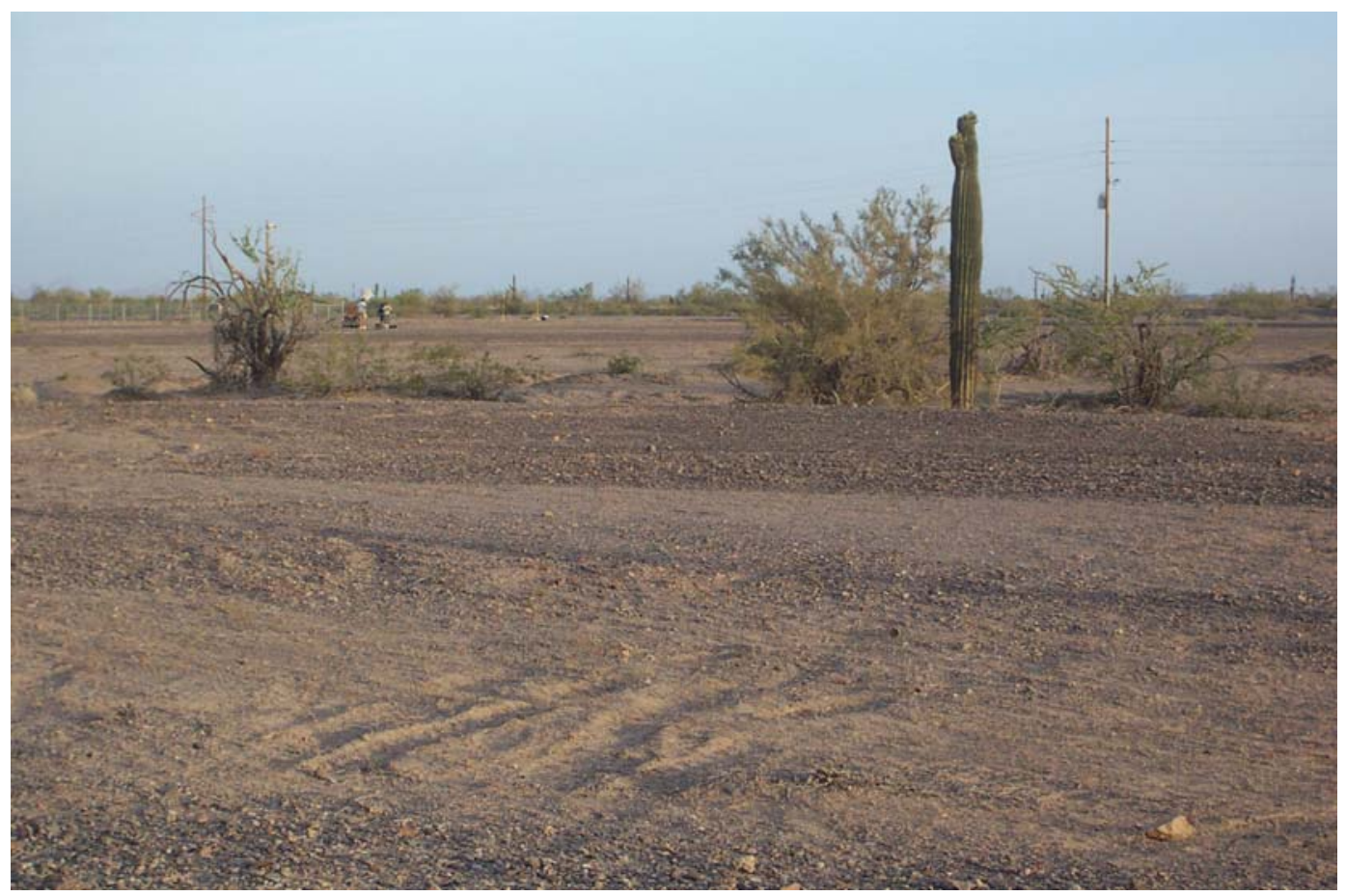

Figure 5. Area weather is arid and warm.

There are two soil complexes present within the site, Riverbend-Carrizo and Cristobal-Gunsight. The Riverbend-Carrizo complex is comprised of mixed stream alluvium, whereas the Cristobal-Gunsight complex is derived from fan alluvium. The Cristobal-Gunsight complex covers the majority of the site. Most of the soil samples are classified as either a sandy loam or loamy sand, with most samples containing gravel-size particles. An x-ray diffraction analysis was conducted on four soil samples and determined that the basic mineralogy consists of quartz, calcite, mica, feldspar, magnetite, and some clay. The soils in the extreme desert region may have a horizon of calcium carbonates that tend to cement together in the soil, producing hard layers in the subsurface. The presence of magnetite imparts a moderate magnetic susceptibility, with volume susceptibilities generally greater than $1.00 \times 10^{-3} \mathrm{SI}$.

\section{Field activities}

\section{Setup/mobilization}

Setup/ mobilization activities included initial mobilization, daily equipment preparation, and demobilization. A four-person crew took $4 \mathrm{hr}$ $45 \mathrm{~min}$ to perform the initial setup and mobilization. Daily equipment preparation took approximately $1 \mathrm{hr}$. Daily battery changes and data 
downloading activities totaled $1 \mathrm{hr}$ for the BTG. The ERDC team constructed a calibration test pit, a hole $1 \mathrm{~m}$ by $0.5 \mathrm{~m}$ by $1 \mathrm{~m}$ (length, width, and depth), to allow the collection of signature data of all items with various orientations.

\section{Calibration}

Personnel of the ERDC collected data for approximately $2 \mathrm{hr}$ in the calibration lane on 9 May. Data were also collected in the calibration test pit on 11 May using the 14 standard inert ordnance targets as shown in Figure 5. No other calibration activities were performed while surveying the BTG.

\section{Equipment/data checks, maintenance}

Equipment/ data checks and maintenance activities accounted for approximately 10 min of site usage time in the BTG.

\section{Equipment failure or repair}

No equipment failures occurred while the ERDC team surveyed in the BTG. However, problems were experienced with the prototype manportable pushcart in the open field test area. The nylon bolts used to anchor the wheels to the platform became stripped after minimal use. This equipment failure accounted for 50 min of downtime on 9 May. The problem was initially corrected by replacing the nylon bolts. The first week involved repeated tightening of the nylon bolts until the equipment experienced complete failure using nylon bolts. During week 2 , corrections were made using an assortment of improvised non-metal devices that were procured from a local hardware store. 


\section{System Descriptions}

\section{GEM-3-E system description}

The GEM-3-E is a broadband, programmable electromagnetic (EM) sensor. The GEM-3-E consists of a circular sensor, a three-button user interface or Personal Data Assistant graphical interface, an electronics console, and WinGEM software. The sensor is available in three different sizes. The 40-cm and 64-cm sensors come mounted on booms for handheld operation; whereas, the $96-\mathrm{cm}$ sensor is usually mounted on a wheeled cart.

\section{System specifications GEM-3-E}

- Multiple-frequency operation: up to 15 frequencies

- Frequency band: 330 to $47970 \mathrm{~Hz}$

- Coil configurations: horizontal coplanar

- Battery: standard 12-volt notebook computer battery (B905S)

- Battery life: $\sim 4 \mathrm{hr}$

- Weight: $9 \mathrm{lb}(4 \mathrm{~kg})$

- Basic output: in-phase and quadrature response in parts per million (ppm)

- PC software: WinGEM2k

- Positioning: Utilizing real-time GPS data

\section{System configuration GEM-3-E}

The GEM-3-E cart system as used at YPG consisted of the 96-cm head with the data acquisition box, and a Trimble 4700 GPS rover. The GPS rover was removed from the backpack and secured to a mast centered above the GEM-3-E sensor head of the GPS antenna. The controller box was attached to the GEM-3-E adjacent to the Hewlett Packard Palm computer (iPAQ), where the operator could monitor the validity of the positioning data (see Figure 6). Frequency data were collected simultaneously for 90, 210, 390, 750, 1470, 2910, 5850, 11430, 21690 and $41010 \mathrm{~Hz}$. 


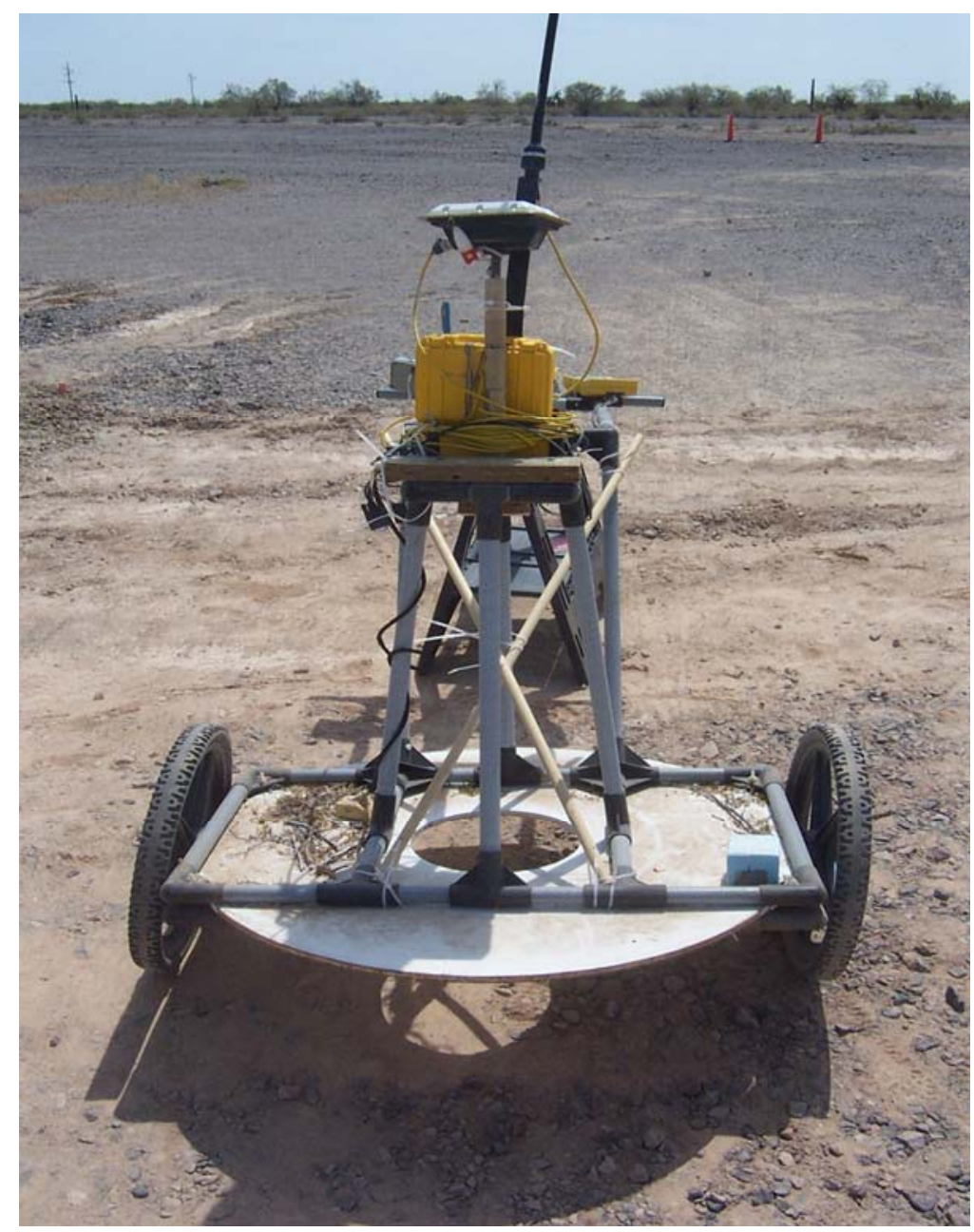

Figure 6. The GEM-3-E cart system with controller and GPS.

\section{Positioning system}

\section{System specifications}

Real-Time Survey Performance (Requires Trimble handheld survey controller model TSC1 ${ }^{T M}$ with Trimble Survey Controller ${ }^{T M}$ software.)

- Modes: Real-time stop-and-go, Real-time continuous

- Precision:

$\begin{array}{lll}\text { Modes } & \text { Latency } & \text { Accuracy } \\ \text { 1 Hz fine } & 0.4 \mathrm{sec} & \pm 1 \mathrm{~cm}+2 \mathrm{ppm} \text { Horizontal } \\ & & \pm 2 \mathrm{~cm}+2 \mathrm{ppm} \text { Vertical } \\ 5 \mathrm{~Hz} \text { fine } & 0.1 \mathrm{sec} & \pm 3 \mathrm{~cm}+2 \mathrm{ppm} \text { Horizontal } \\ & & \pm 5 \mathrm{~cm}+2 \mathrm{ppm} \text { Vertical }\end{array}$

- Coarse $20 \mathrm{~cm}$ RMS

- Range: Up to $10 \mathrm{~km}$, depending on radios used 
Initialization

- Type: Automatic while moving (on-the-fly [OTF]) or static

- Typical Reliability: $99.9 \%$

- Time: <1 minute typical

General performance

- Tracking: 9 channels (12 channels for CORS system only)

- L1C/A code, L1/ L2 full-cycle carrier

- Fully operational during P-code encryption

- Data logging: Data are logged internally (Additional data storage in the TSC1 or on the optional removable PC cards available for the TSC1)

- Internal Data Storage: $120 \mathrm{hr}$ of L1/ L2 data while tracking six satellites at standard output 15-second epoch interval

- Standard Input/ Output: RTCM SC-104 input version 2.1

- NMEA-0183 Navigation output

Internal receive only radio modem performance (requires internal radio modem)

- Modes: High gain UHF

- Range: Base Radio Modem

- TRIMTALK $^{\mathrm{TM}} 450 \mathrm{~S}$ TRIMMARK ${ }^{\mathrm{TM}}$ IIe

- Optimal: $10 \mathrm{~km} 15 \mathrm{~km}$

- Typical: 3-5 km 10-12 km

- Radio Modem:

- Freq. Range: $410-420$ MHz, 430- 440 MHz, 440- 450 MHz, 450- 460 MHz or 460- $470 \mathrm{MHz}$ (only one per model)

- Channels: Up to 20 (factory pre-set)

- Channel Spacing: $12.5 \mathrm{KHz}$ or $25 \mathrm{KHz}$ (only one per system)

- Wireless Data Rates: 4,800 and 9,600 bps

- Modulation: GMSK

\section{System configuration}

Real-time kinetic (RTK) GPS positioning was collected using a Trimble Pathfinder 4700 series rover and base station for differential GPS (DGPS). With the rover GPS system (receiver and antenna) mounted on a mast located $1.5 \mathrm{~m}$ above the center of the head on the GEM-E unit, there was no offset correction required. The moving accuracy of the DGPS for this system was on the order of $2 \mathrm{~cm}$. However, due to the rotation of the mast 
above the wheels, errors of $10 \mathrm{~cm}$ or greater were experienced. Positional data were logged simultaneously in the GEM-3-E data acquisition console and the Trimble data logger. 


\section{Data Collection Procedure}

\section{Survey setup}

Data were collected over the calibration lanes and the BTG areas. These areas have lanes designating the possible locations of targets. Additionally, these lanes are marked with sections of PVC pipe driven into the ground at 1-m intervals. A 50-m tape was laid at both ends of the areas to designate the line spacing. Also, nylon lines were laid out between the tapes to measure 2-m intervals. By lining up with the wheels alternating either on the line or straddling it, the operator was able to collect data at $1 / 2-\mathrm{m}$ spacing. Data collected between two lines at the $1 / 2-m$ mark are shown in Figure 7.

The open field area was subdivided into smaller grids so that data could be acquired in more manageable segments. Typically a 100-m grid was selected, but there were exceptions due to site topography. Ropes were stretched between surveyed points to create gridded lanes over this area in a manner similar to the BTG and calibration areas. Data in this grid were collected in segments and downloaded. During the break, lane marker ropes were moved.

These data would then be reviewed for QA/ QC. If there was a problem data were corrected in a timely manner. A similar procedure was used in the desert extreme. Although the moguls were divided into two areas, they were acquired in a single grid.

\section{Quality assurance/quality control procedures}

There were a number of standard measures that the ERDC team used to ensure the quality of the data collected during the field investigation. Inspection of coverage maps was the first step. The data were corrected for GPS drift and viewed in pseudo three-dimensional (3-D) to look at the quality of the sensor positioning response. Statistical analysis was also performed on the data, and calibration source responses were analyzed to quantify data drift. 


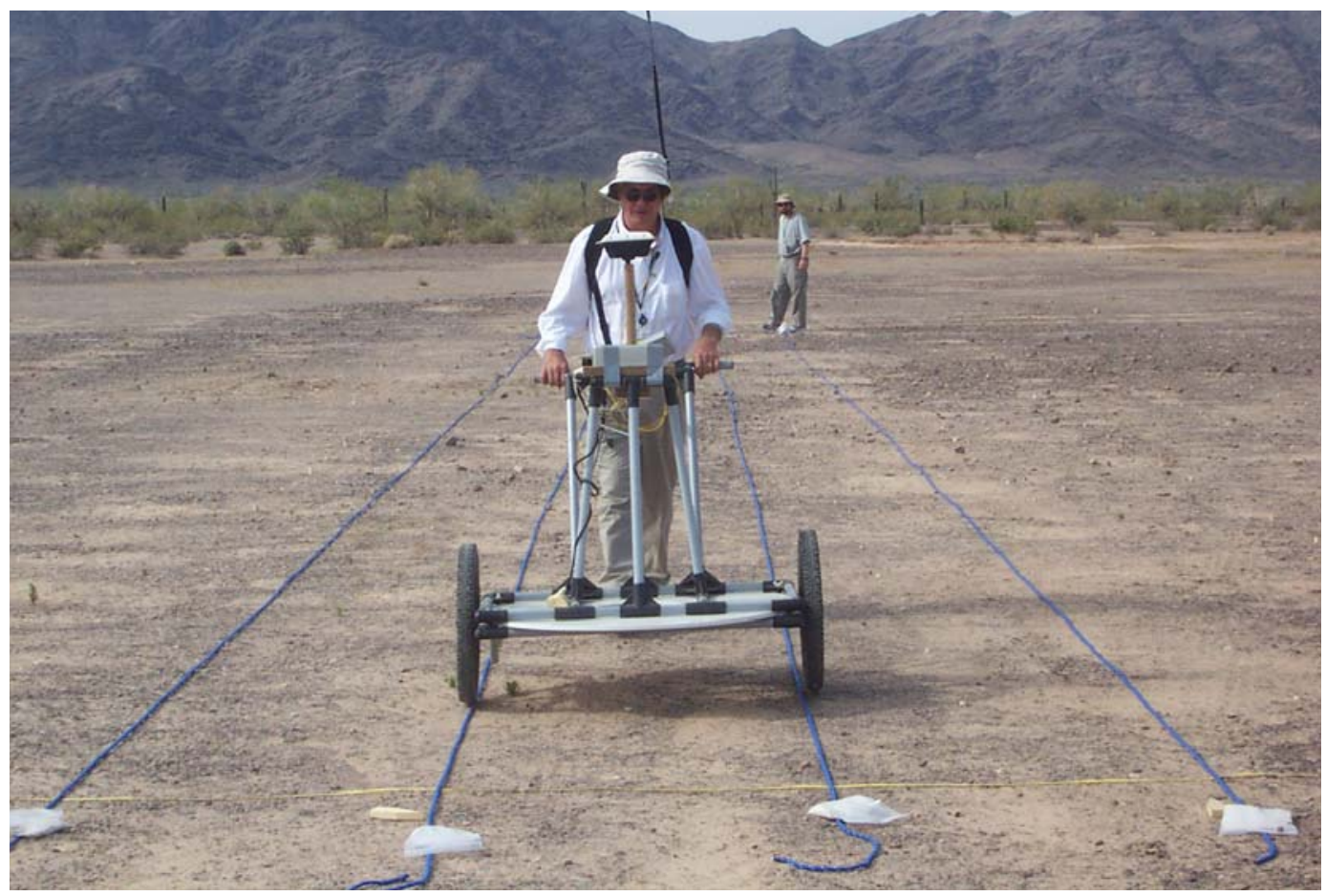

Figure 7. The GEM-3-E with ropes marking survey grid lines.

\section{Coverage maps}

The first QA/ QC function was to examine the spatial distribution of the acquired data to ensure that the survey area was adequately covered. After each data acquisition event and upon data being downloaded, a line path plot was generated delineating the collected data. This method of data visualization was used to verify that no significant gaps were present in the newly acquired data or between the new data and the previously acquired data. When all the data for an area were collected, a coverage map of the area was generated using the Geosoft UX-Detect software module. A grid of a user-selected ground resolution was created and the survey points that pass through each grid are counted and displayed on a color-coded map. Grid cells with a value of zero, which is displayed in white, indicate gaps in area coverage at the resolution being displayed. A coverage map was generated for each instrument at two resolutions: $0.5 \mathrm{~m}$, which was the nominal line spacing for this data collection, and $0.75 \mathrm{~m}$. If the survey lines were walked perfectly and no positioning error was present, then the 0.5 -m coverage map would show $100 \%$ coverage. Due to imperfections in the data acquisition process, some small gaps in coverage may appear in the 0.5-m coverage maps; however, these gaps should disappear in the 0.75- $\mathrm{m}$ coverage map. Gaps in the $0.75 \mathrm{~m}$ coverage map would indicate 
significant departures from the desired sampling coverage. Coverage maps are discussed in more detail in Chapter 5.

\section{GPS corrections}

GPS data were collected using a Trimble Pathfinder 4700 series rover and base station for differential GPS. In this configuration, the accuracy is between 2 and $10 \mathrm{~cm}$.

Due to an internal lag between the synchronization of the input port on the GEM-3-E and the output of the DGPS system, it was necessary to correct the merged data stream to insure that the position data and the measured electromagnetic data were correctly collocated. Values observed for the magnitude of this drift typically ranged from 0.5 to 1.5 seconds, and the drift is thought to be caused by either the initial states of the buffers in the two instruments or in the overhead requirements of raw data processing. During post-processing, it was observed that once a correction value was found in the data, this value can be continually applied to subsequent collected data (since this lag is constant) or until the GPS unit is re-initialized.

Each data collection commenced with a calibration and synchronization procedure to determine the magnitude of the lag. The instrument was placed on a ferrite core calibration item (see Figure 8) with the DGPS streaming position data and the data acquisition on the GEM-3-E initiated. The instrument was moved forward a distance of $3 \mathrm{~m}$ and stopped. After a brief pause, the instrument was rolled back across the item to a distance $3 \mathrm{~m}$ behind the item and stopped. Finally, the sensor was moved back across the item and into the grid to begin the data collection run.

Data were collected for the 14 standardized test items in the test pit adjacent to the calibration lanes (see Figure 9) starting at the orange cones. The $1 / 2$-in. $(1.27-\mathrm{cm})$ plywood was placed over the hole to facilitate rolling the GEM-3-E over the items without having to completely fill in the hole before data collection. Ordnance items were positioned in the pit to give $0^{\circ}, 45^{\circ}, 90^{\circ}$, and $180^{\circ}$ angles of orientation (see Figure 8 ). These data were used for algorithm training and discrimination processing. 


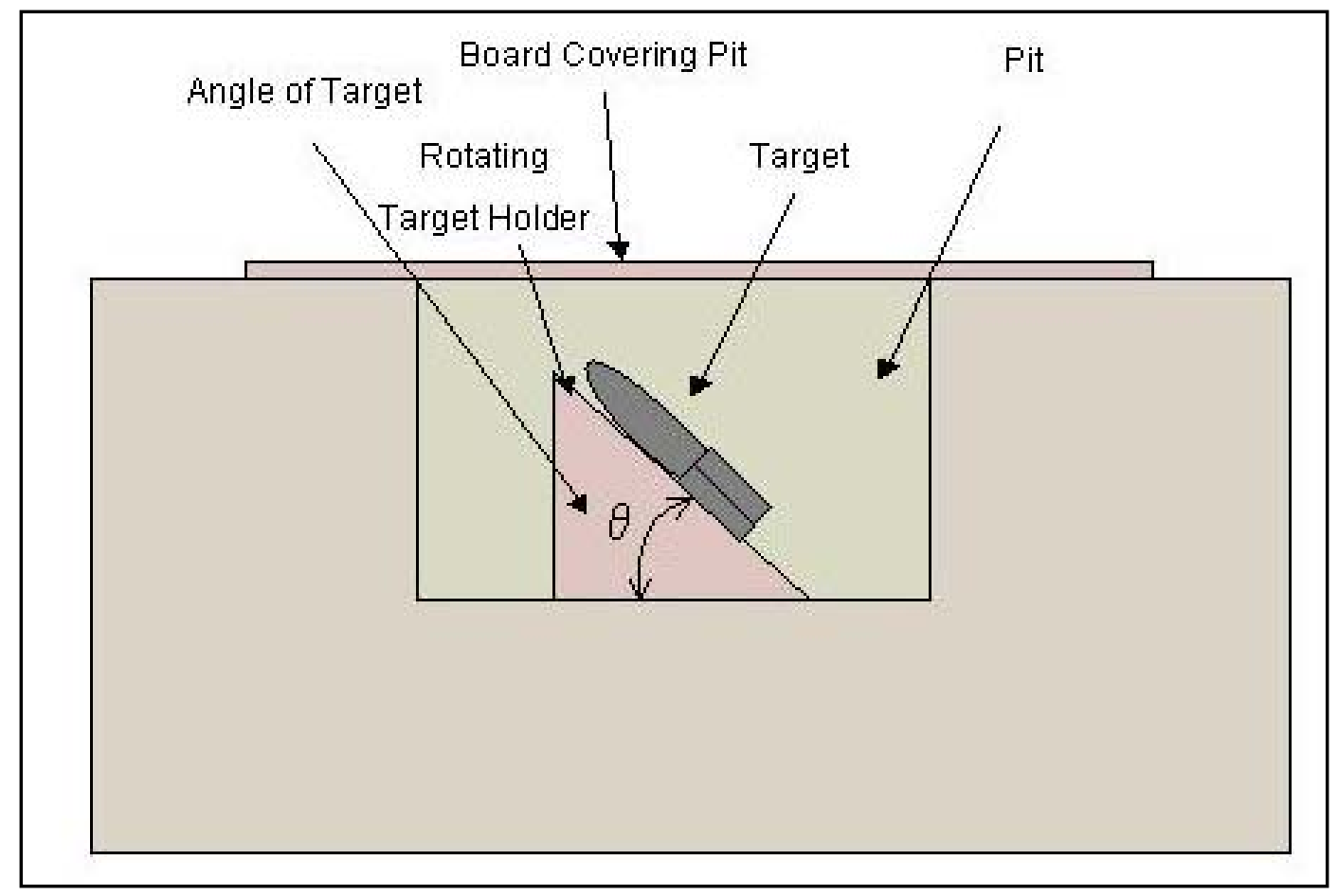

Figure 8. The calibration pit site configuration.

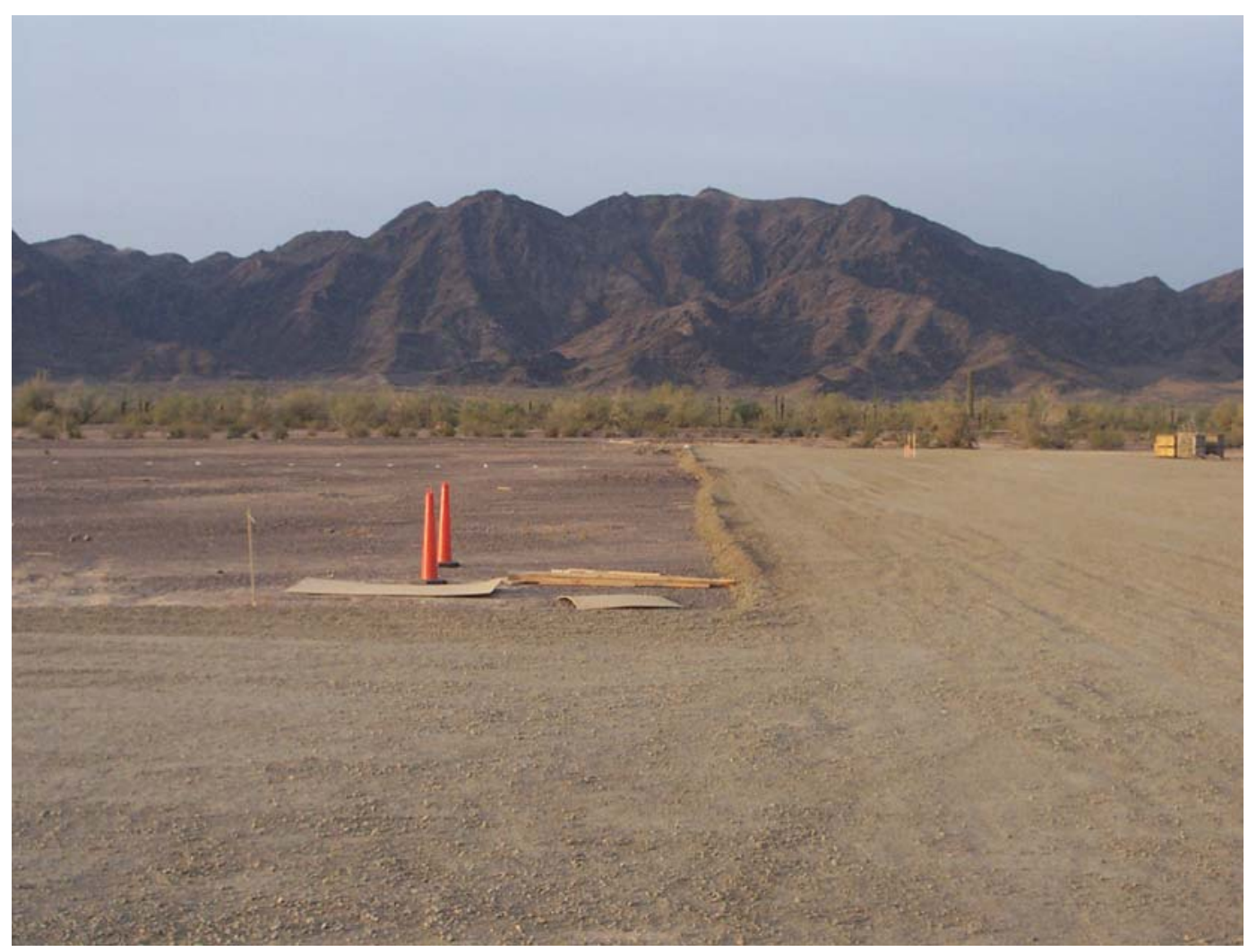

Figure 9. The calibration pit located next to calibration lanes. 
Figure 10 shows an idealized data set from which the speed of the sensor and the sensor response are normalized and plotted on the same graph. The initial speed of the sensor is at zero and the sensor response is at a maximum. As the sensor is pushed past the item, the sensor response declines and the sensor speed rises. For this example, the change in speed from the sensor lags the decrease in sensor response. Measurement along the time axis will give the magnitude of the lag. The magnitude of the difference was used to shift the data so that the two streams are synchronized as illustrated in Figure 11.

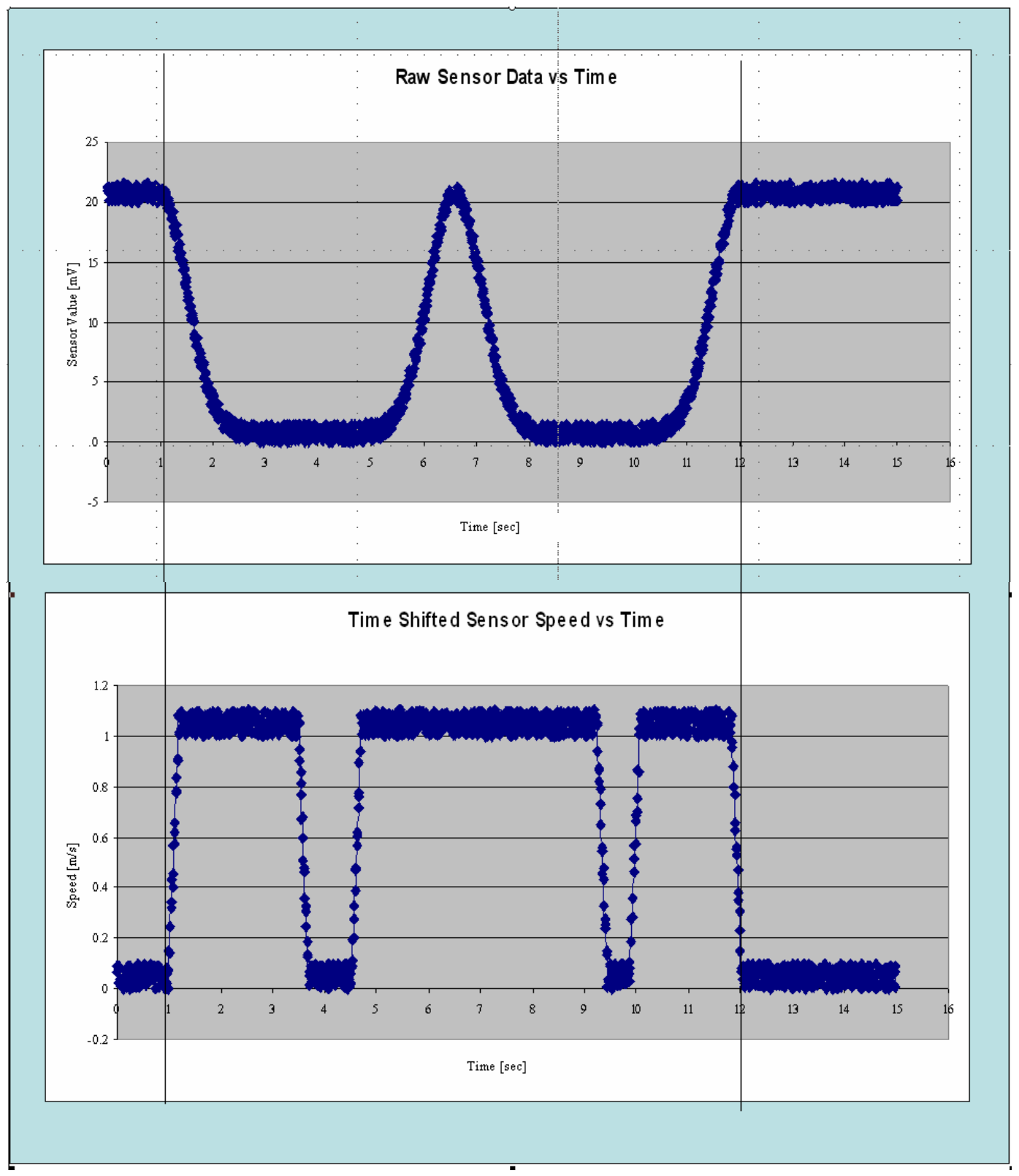

Figure 10. Idealized uncorrected GEM-3-E sensor speed and sensor response versus time. 

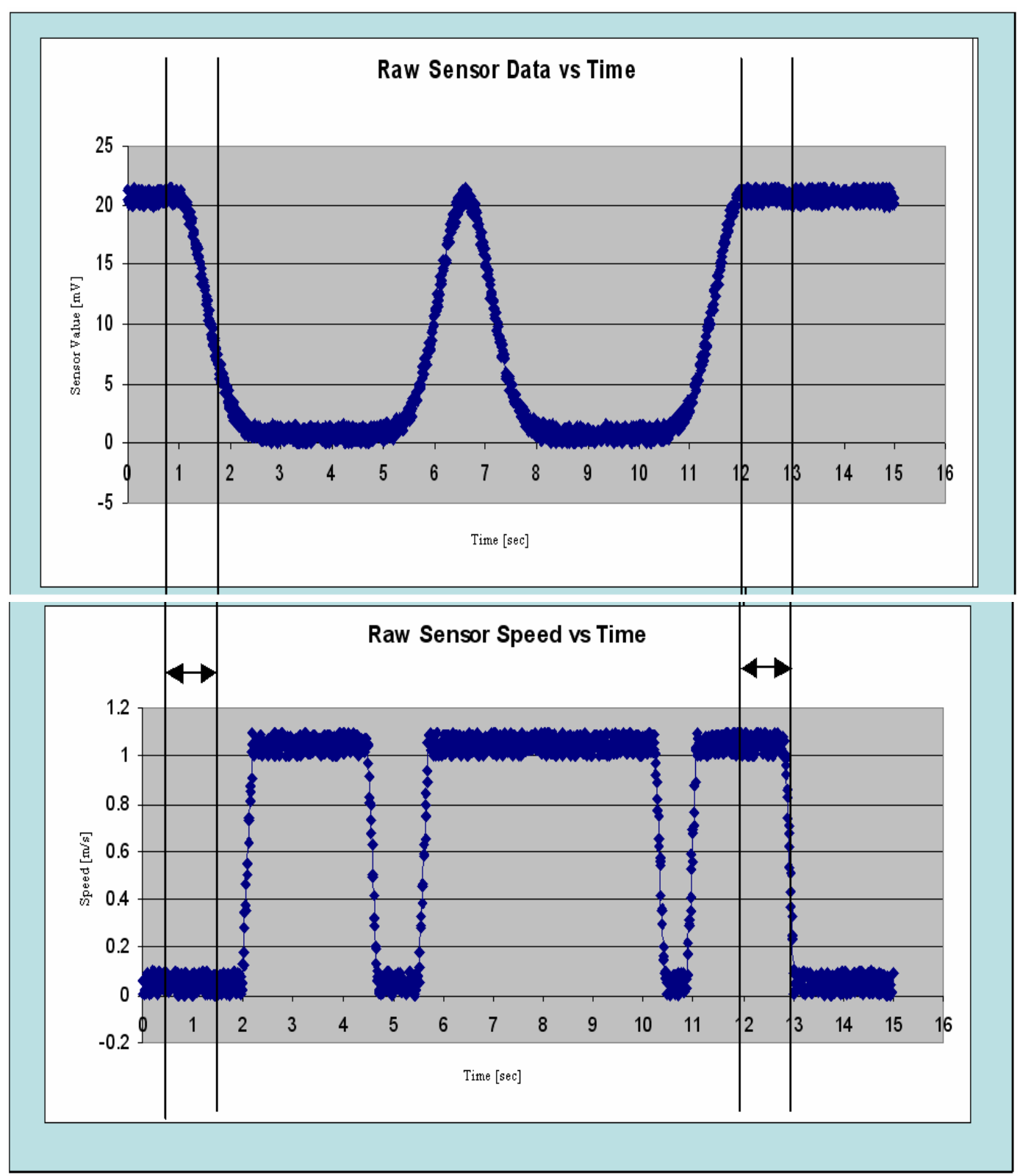

Figure 11. Idealized corrected GEM-3-E sensor speed and sensor response versus time.

Once the data are synchronized there is an additional check to insure the correctness of the drift. If the data are plotted on a surface map with $\mathrm{x}, \mathrm{y}$, the color of the point as sensor response, and with the drift corrected, then all three passes over of the item will appear as a single anomaly on the graph. An anomaly is a localized region within these data that exhibits a change in sensor response value greater than some baseline selected during post-processing. Data not synchronized will shift anomalies. An 
example of raw data for the passes over an item can be seen in Figure 12. After the correction, the seemingly multiple targets converge into a larger single feature as shown in Figure 13. This represents a truer signature of the anomaly detection.

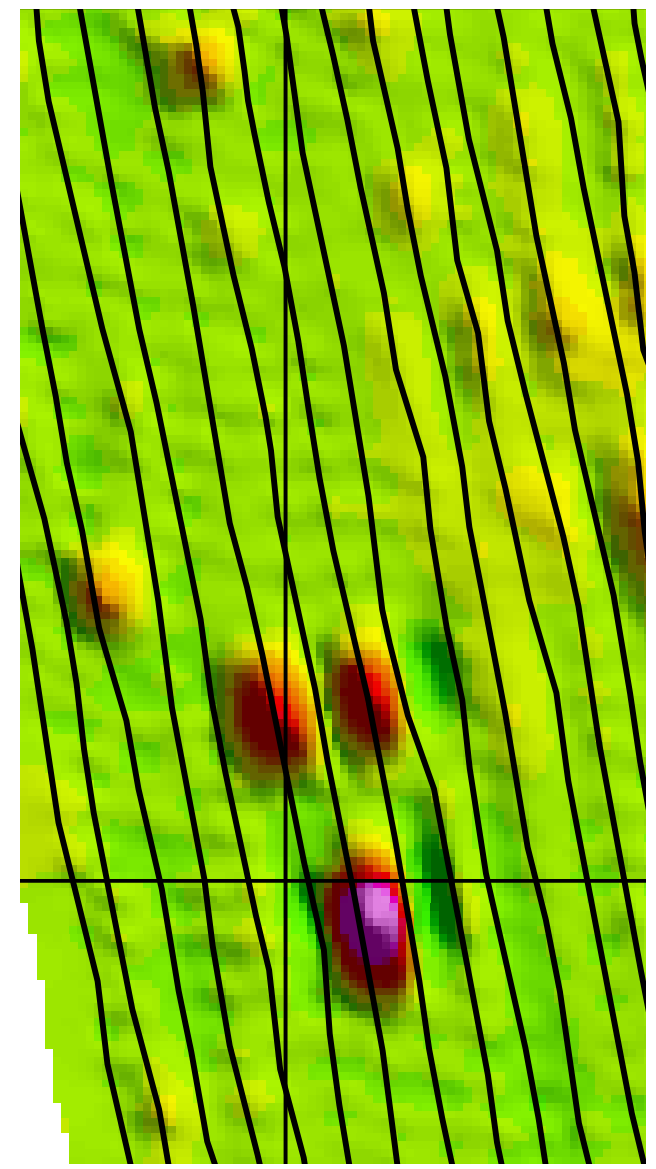

Figure 12. GEM-3-E raw data for the passes over an anomaly before lag correction.

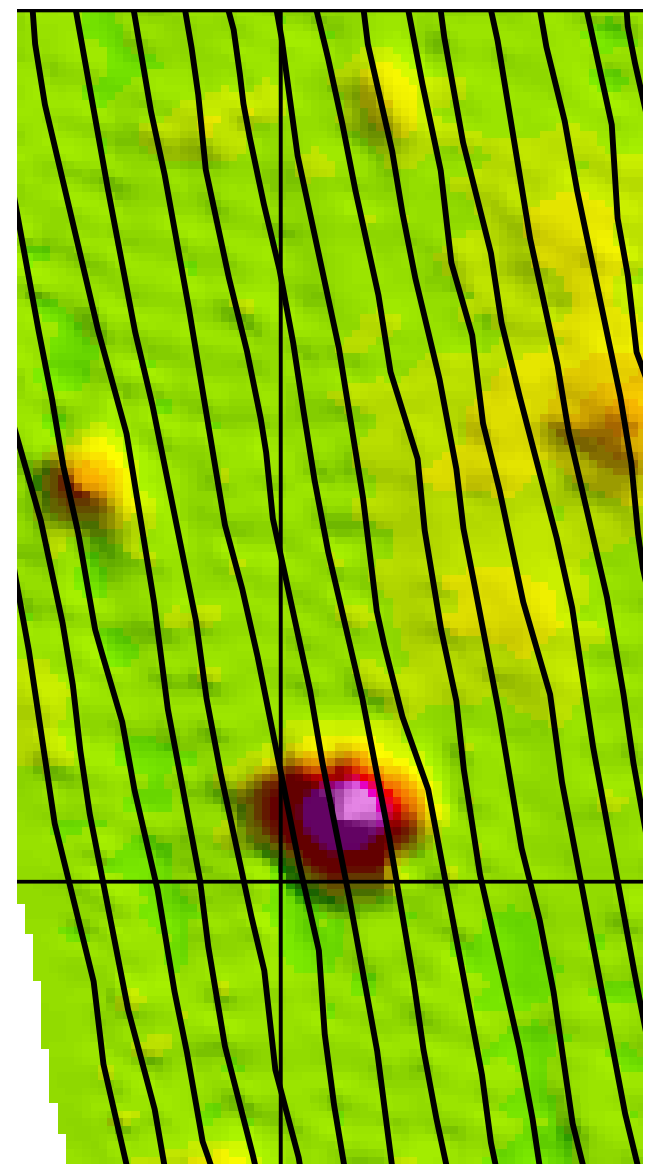

Figure 13. GEM-3-E data for the passes over an anomaly after lag correction.

\section{Drift correction}

A common problem encountered when collecting geophysical data is instrument drift (see Figure 14). The GEM-3-E signal level varies with time during data collection due to changes in temperature and battery power output. The Geosoft UX-Detect drift correction algorithm was applied to the data collected with the GEM-3-E system at YPG to compensate for this drift. This algorithm calculates the average for each user-specified block of data and subtracts the average from all points in the block. A percentage of points at the high and/ or low end of the range of values are excluded from the calculation of the average so that the 
presence of targets in the data block does not skew the average. Ideally, only background points will be included in the calculation of average; however, this can be difficult to achieve in areas densely populated with targets. Figure 14 shows a single channel of data for one survey line before and after drift correction. The uncorrected data, shown in red, have a significant downward drift, which is no longer present in the corrected data that are shown in green. Drift correction is performed on each data channel independently.

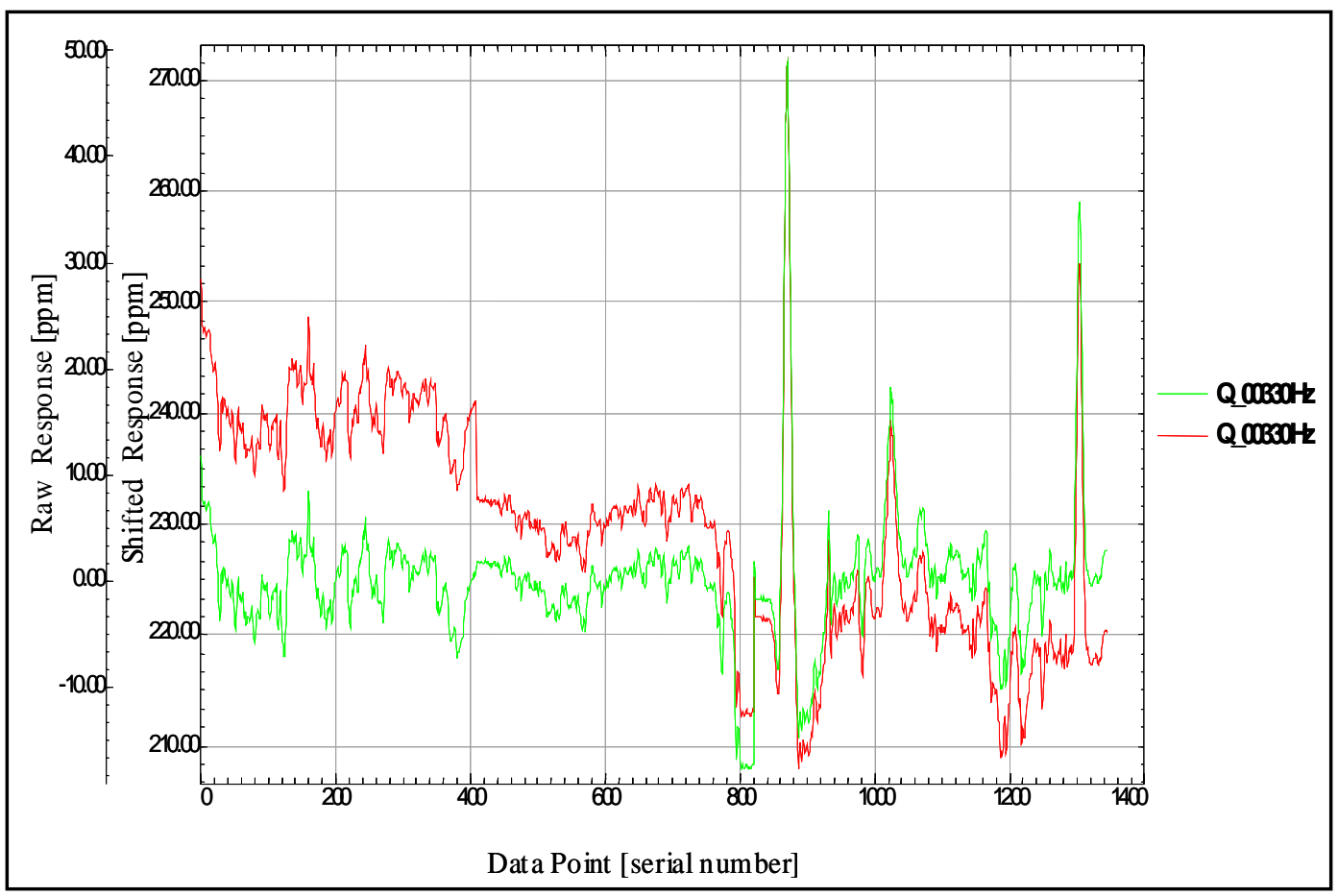

Figure 14. GEM-3-E (330 Hz) drift corrected (green) and uncorrected (red) signal levels. 


\section{Data Collection GEM-3-E}

\section{GEM-3-E system operation}

Prior to the collection of each data acquisition grid, the GEM-3-E cart was positioned with the sensor head directly over the ferrite core. When data acquisition was initiated, the system was left over a ferrite core for 2 to 3 seconds to allow the system to "warm up." The cart was rolled backwards off the core then run back over the core twice. This gave a precise start and stop time so any time lag in the GPS could then be corrected.

The GEM-3-E was rolled into position for the next data acquisition lane. Once the GEM-3-E was positioned on the correct line, the operator started data collection and walked down the lane. At the end of every lane, the data acquisition was stopped and the lane number was advanced.

\section{GEM-3-E data storage}

There are two GEM-3-E data storage systems available. The data were either stored on the data acquisition module or on an iPAQ. The iPAQ was only used one day.

When the data were stored on the data acquisition module, they were downloaded to the computer using the WinGEM2K software via a serial port connection. The data acquisition module was powered on and the WinGEM2K software was initiated. From the tool bar, the download data were selected. The file was named and a download location was selected.

When the iPAQ was used to store data, a different procedure was used for download and director selection. The iPAQ was disconnected from the GEM-3-E and connected to the laptop by a USB connection. The ActiveSync program was activated and the files were downloaded to the laptop hard drive. These files were then copied to a new directory for further analysis.

\section{GEM-3-E GPS sensor data integration}

A GEM-3-E input port was used to facilitate the integration of GPS data. Care was taken to synchronize the data streams and to remove lag, which 
was discussed in the post-processing QA/ QC Procedures GPS Corrections section.

\section{GEM-3-E coverage maps}

The gridded coverage maps of the GEM-3-E are as follows: Figure 15 shows the line path covered by the GEM-3-E. Small gaps appeared in the 0.5-m coverage map, as shown in Figure 16, but disappeared with a grid cell resolution of $0.75 \mathrm{~m}$ (see Figure 17). This indicates that while there were a few departures from the nominal line spacing of $0.5 \mathrm{~m}$, none of them were very large.

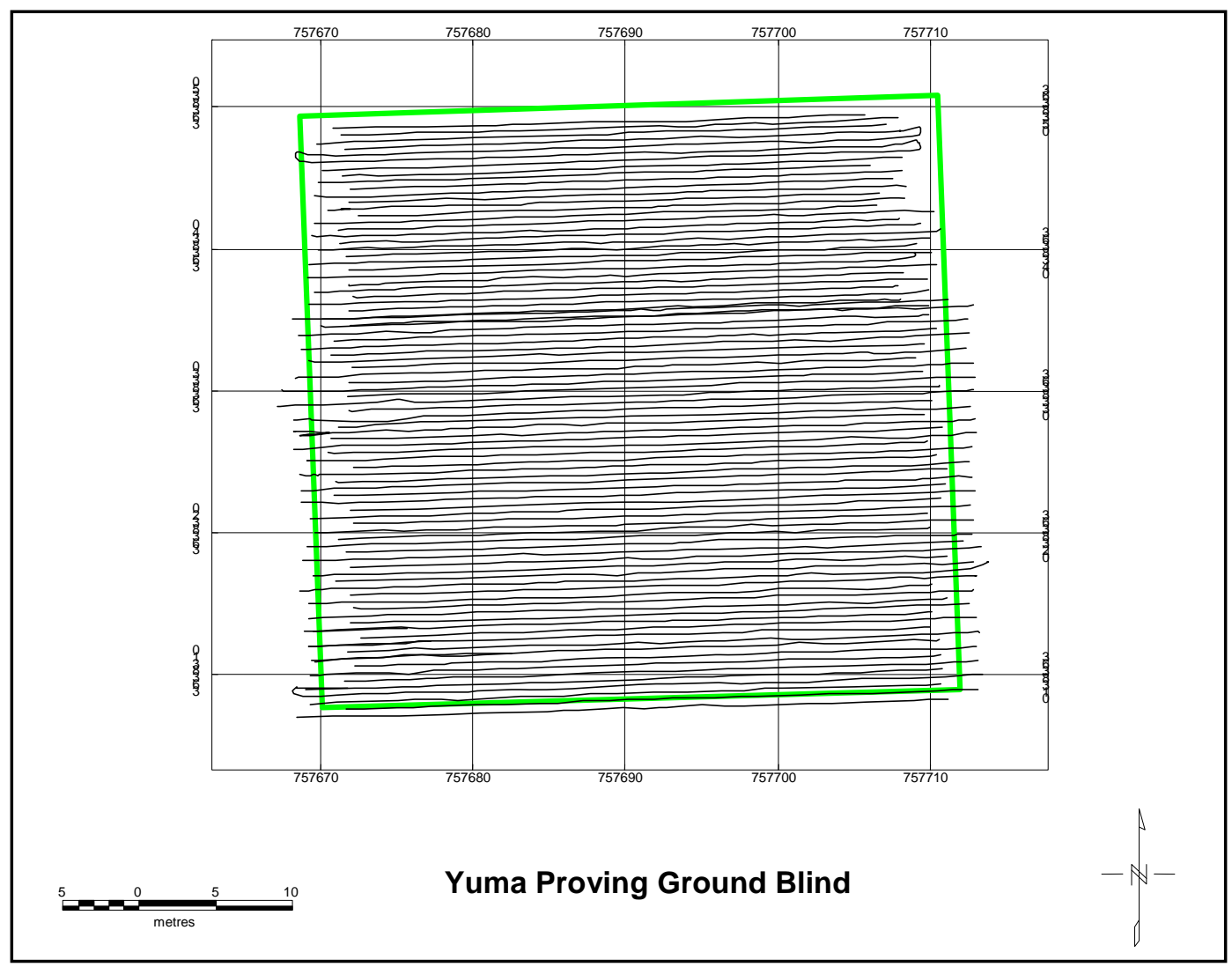

Figure 15. GEM-3-E site traverses. 


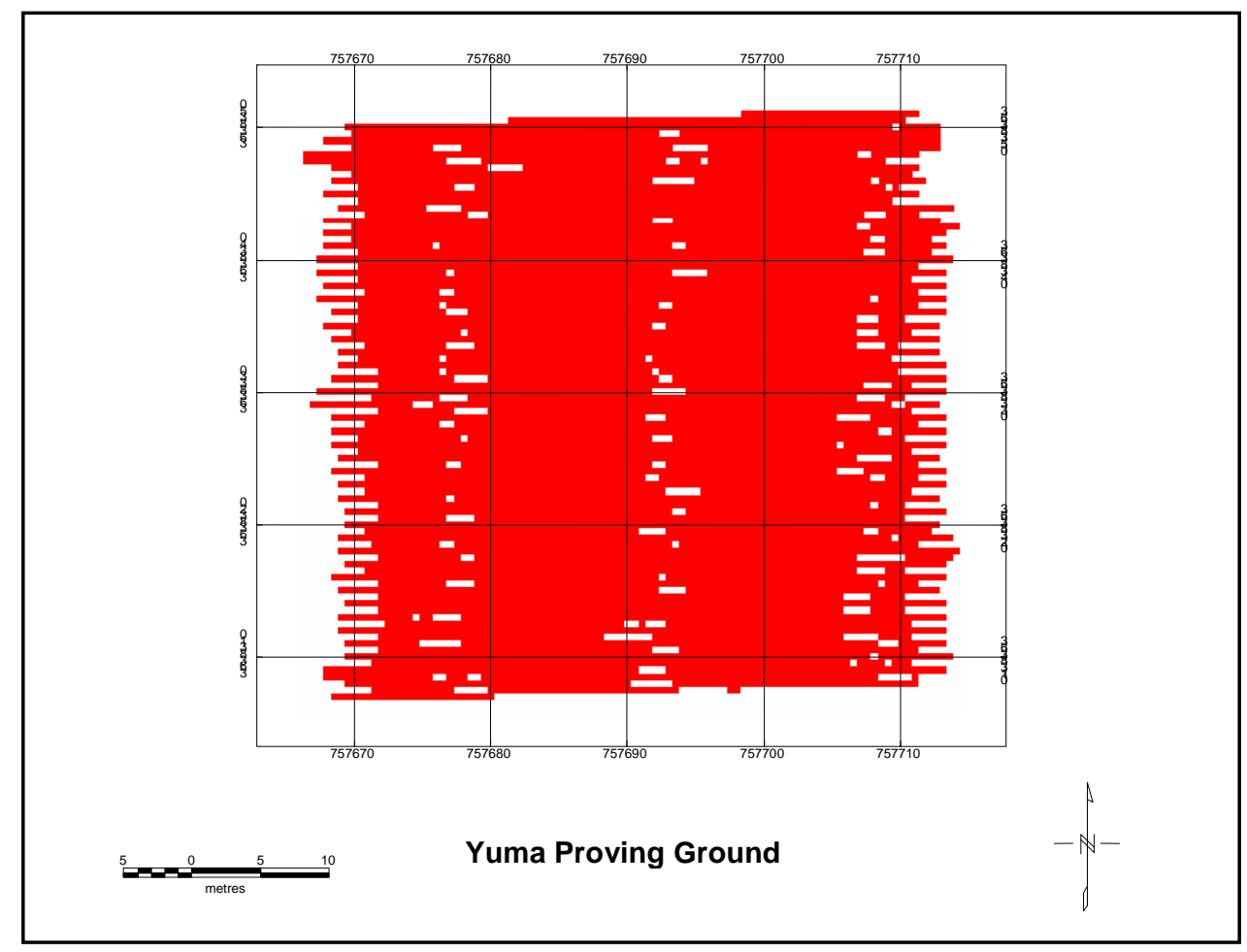

Figure 16. GEM-3-E coverage map using 0.5-m grid spacing.

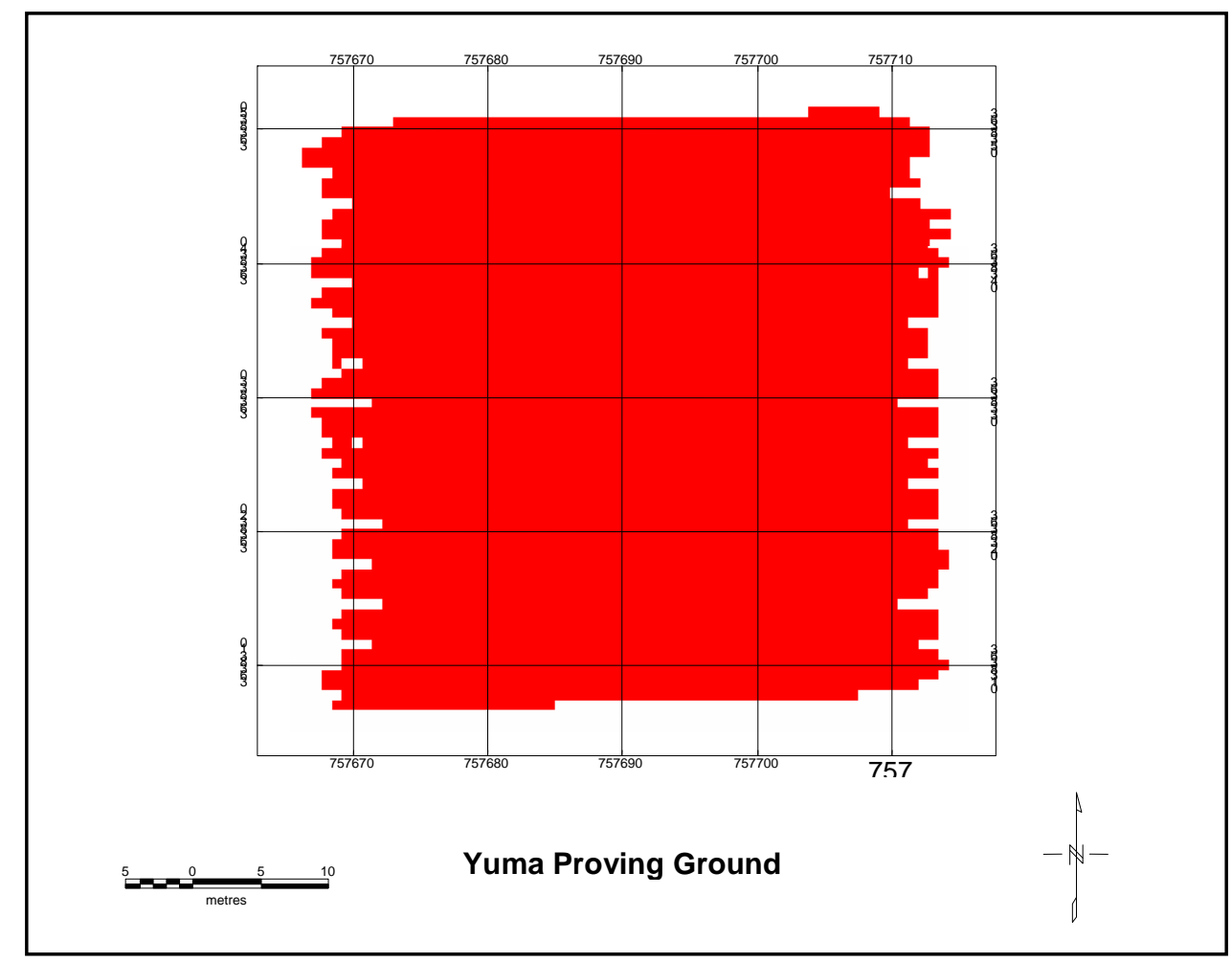

Figure 17. GEM-3-E coverage map using 0.75-m grid spacing. 


\section{System Evaluation GEM-3-E}

\section{Scoring of system}

The scoring results obtained from the ATC for the GEM-3-E (USAEC 2005a, 2005b, 2005c, 2005d) are provided in Tables 2 to 5. The performance of the GEM-3-E was better at the Aberdeen Proving Ground (APG) test site (Bennett et al. 2006) with a probability of detection $\left(\mathrm{P}_{\mathrm{d}}\right)$ of 0.60 for the response stage. This was due to a higher signal noise ratio (SNR) of the GEM-3-E system used at the APG test site. The systems used at the two sites were different instruments of the same model. The following variable definitions were obtained from the ATC website as follows (see Appendix D):

- $\mathrm{P}_{\operatorname{det}} \mathrm{dsc}=(\#$ of discrimination-stage detections $) /($ \# of emplaced ordnance in the test site).

- $\mathrm{P}_{\text {det }^{\text {res }}}=$ (\# of response-stage detections)/ (\# of emplaced ordnance in the test site).

- $\mathrm{P}_{\mathrm{fp}}$ res $=$ (\# of response-stage false positives)/ (\# of emplace clutter items).

- Emplaced Ordnance - An inert ordnance item buried by the government at a specified location in the test site.

- Emplaced Clutter - A clutter item (i.e., non-ordnance item) buried by the government at a specified location in the test site.

- Discrimination Stage - The ability to correctly identify ordnance as such, and to reject clutter. For the same locations as in the RESPONSE STAGE anomaly column, the DISCRIMINATION STAGE column contains the output of the algorithms applied in the discriminationstage processing. This column is prioritized based on the confidence that an ordnance item is present at the specified location. For electronic signal processing, priority ranking is based on algorithm output. For other systems, priority ranking is based on human judgment. The demonstrator also selects the threshold that provides optimum system performance, (i.e., that retains all the detected ordnance and rejects the maximum amount of clutter).

- Response Stage - The ability of the demonstrator's system to detect emplaced targets without regard to ability to discriminate ordnance from other anomalies. The RESPONSE STAGE provides the location and signal strength of all anomalies deemed sufficient to warrant 
further investigation and / or processing as potential emplaced ordnance items. This list is generated with minimal processing (e.g., this list will include all signals above the system noise threshold). As such, it represents the most inclusive list of anomalies.

Results for the BTG are analyzed by size, depth, standard and nonstandard ordnance which are presented in Table 2. The standard column of Table 2 represents the targets which are the following ordnances: $20 \mathrm{~mm}, 40 \mathrm{~mm}$, M42, BLU-26, BDU-28, $57 \mathrm{~mm}$, MK118, $60 \mathrm{~mm}, 81 \mathrm{~mm}, \mathrm{M} 230,105 \mathrm{~mm}$, and $155 \mathrm{~mm}$ (see Figure 18). The nonstandard column is reporting on the other ordnances buried at YPG test site. Results by size and depth include both standard and nonstandard ordnance. The results by size show how well the ERDC team did at detecting/ discriminating ordnance of a certain caliber range. The results are relative to the number of ordnances emplaced. Depth is measured from the closest point of anomaly to the ground surface.

The RESPONSE STAGE results are derived from the list of anomalies above the demonstrator-provided noise level threshold. The results for the DISCRIMINATION STAGE are derived from the demonstrator's recommended threshold for optimizing UXO field cleanup by minimizing false digs and maximizing ordnance recovery. The lower 90-percent confidence interval (CI) on probability of detection and probability of false positive was calculated assuming that the number of detections and false positives are binomially distributed random variables. All results in Table 2 have been rounded to protect site ground truth. However, lower confidence limits were calculated using actual results. The response stage noise level threshold was set to $50 \mathrm{ppm}$ for the quadrature sum while the discrimination stage was thresholded with $70 \mathrm{ppm}$ for the quadrature sum. In Table 2 through Table 5, the discrimination stage shows a slight decrease in the $\mathrm{P}_{\mathrm{d}}$ value due to the different thresholds. 


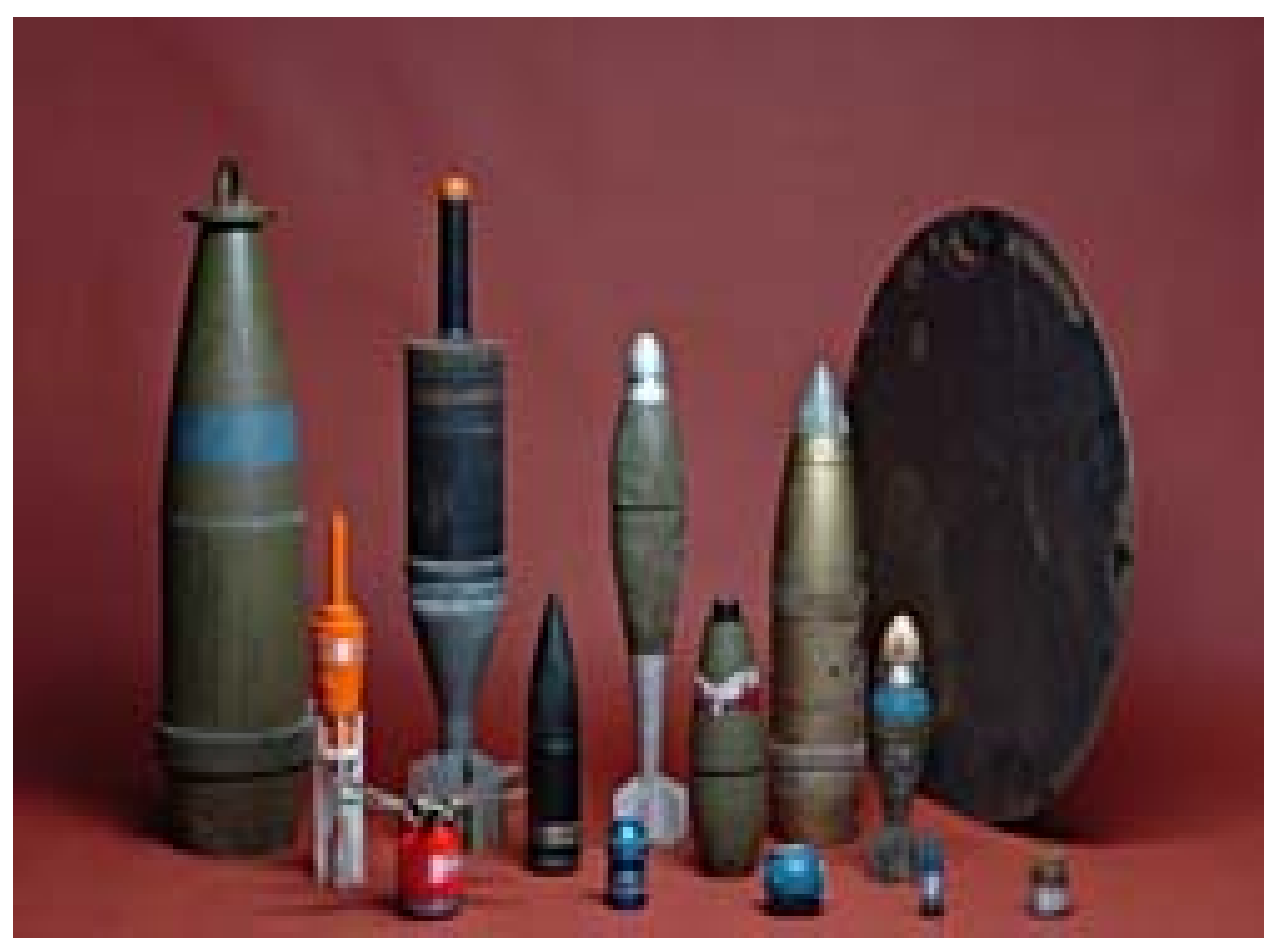

Figure 18. Standard inert ordnance targets.

Table 2. Enhanced GEM-3/pushcart - blind grid results (USAEC 2005a).

\begin{tabular}{|c|c|c|c|c|c|c|c|c|c|}
\hline \multirow[b]{2}{*}{ Metric } & \multirow[b]{2}{*}{ Overall } & \multirow[b]{2}{*}{ Standard } & \multirow[b]{2}{*}{ Non-standard } & \multicolumn{3}{|c|}{ By Size } & \multicolumn{3}{|c|}{ By Depth, $\mathrm{m}$} \\
\hline & & & & Small & Medium & Large & $<0.3$ & $0.3-<1$ & $>=1$ \\
\hline \multicolumn{10}{|c|}{ RESPONSE STAGE } \\
\hline$P_{d}$ & 0.45 & 0.45 & 0.50 & 0.30 & 0.50 & 0.80 & 0.50 & 0.50 & 0.00 \\
\hline $\mathrm{P}_{\mathrm{d}} \mathrm{L} 90 \mathrm{Cl}$ & 0.38 & 0.34 & 0.35 & 0.20 & 0.37 & 0.58 & 0.40 & 0.35 & 0.00 \\
\hline$P_{f p}$ & 0.80 & & & & & & 0.85 & 0.65 & 0.00 \\
\hline$P_{f p} L 90 C l$ & 0.74 & & & & & & 0.79 & 0.50 & \\
\hline $\mathrm{Pba}_{\mathrm{ba}}$ & 0.05 & & & & & & & & \\
\hline \multicolumn{10}{|c|}{ DISCRIMINATION STAGE } \\
\hline$P_{d}$ & 0.45 & 0.40 & 0.50 & 0.25 & 0.50 & 0.80 & 0.45 & 0.50 & 0.00 \\
\hline $\mathrm{Pd}_{\mathrm{d}} \mathrm{L} 90 \mathrm{Cl}$ & 0.35 & 0.30 & 0.35 & 0.15 & 0.37 & 0.58 & 0.36 & 035 & 0.00 \\
\hline$P_{f p}$ & 0.75 & & & & & & 0.80 & 0.55 & 0.00 \\
\hline $\mathrm{P}_{\mathrm{fp}} \mathrm{L9OCl}$ & 0.68 & & & & & & 0.72 & 0.43 & \\
\hline $\mathrm{Pba}_{\mathrm{ba}}$ & 0.00 & & & & & & & & \\
\hline
\end{tabular}


Table 3. Enhanced GEM-3/pushcart - open field results (USAEC 2005b).

\begin{tabular}{|c|c|c|c|c|c|c|c|c|c|}
\hline \multirow[b]{2}{*}{ Metric } & \multirow[b]{2}{*}{ Overall } & \multirow[b]{2}{*}{ Standard } & \multirow[b]{2}{*}{ Non-standard } & \multicolumn{3}{|c|}{ By Size } & \multicolumn{3}{|c|}{ By Depth, $\mathrm{m}$} \\
\hline & & & & Small & Medium & Large & $<0.3$ & $0.3-<1$ & $>=1$ \\
\hline \multicolumn{10}{|c|}{ RESPONSE STAGE } \\
\hline$P_{d}$ & 0.45 & 0.45 & 0.55 & 0.35 & 0.60 & 0.65 & 0.50 & 0.50 & 0.05 \\
\hline $\mathrm{P}_{\mathrm{d}} \mathrm{L} 90 \mathrm{Cl}$ & 0.44 & 0.39 & 0.48 & 0.31 & 0.52 & 0.60 & 0.46 & 0.46 & 0.03 \\
\hline$P_{f p}$ & 0.50 & & & & & & 0.55 & 0.50 & 0.00 \\
\hline $\mathrm{P}_{\mathrm{fp}} \mathrm{L} 9 \mathrm{OCl}$ & 0.50 & & & & & & 0.51 & 0.47 & 0.00 \\
\hline $\mathrm{Pba}_{\mathrm{ba}}$ & 0.15 & & & & & & & & \\
\hline \multicolumn{10}{|c|}{ DISCRIMINATION STAGE } \\
\hline $\mathrm{Pd}_{\mathrm{d}}$ & 0.45 & 0.40 & 0.50 & 0.30 & 0.55 & 0.65 & 0.45 & 0.50 & 0.05 \\
\hline $\mathrm{P}_{\mathrm{d}} \mathrm{L9OCl}$ & 0.41 & 0.37 & 0.44 & 0.27 & 0.50 & 0.57 & 0.43 & 0.44 & 0.03 \\
\hline$P_{f p}$ & 0.50 & & & & & & 0.50 & 0.45 & 0.00 \\
\hline$P_{f p} L 90 C l$ & 0.47 & & & & & & 0.48 & 0.42 & 0.00 \\
\hline $\mathrm{Pba}$ & 0.05 & & & & & & & & \\
\hline
\end{tabular}

Table 4. Enhanced GEM-3/pushcart - moguls results (USAEC 2005c).

\begin{tabular}{|c|c|c|c|c|c|c|c|c|c|}
\hline \multirow[b]{2}{*}{ Metric } & \multirow[b]{2}{*}{ Overall } & \multirow[b]{2}{*}{ Standard } & \multirow[b]{2}{*}{ Non-standard } & \multicolumn{3}{|c|}{ By Size } & \multicolumn{3}{|c|}{ By Depth, $m$} \\
\hline & & & & Small & Medium & Large & $<0.3$ & $0.3-<1$ & $>=1$ \\
\hline \multicolumn{10}{|c|}{ RESPONSE STAGE } \\
\hline$P_{d}$ & 0.30 & 0.30 & 0.35 & 0.20 & 0.35 & 0.65 & 0.35 & 0.35 & 0.15 \\
\hline $\mathrm{Pd}_{\mathrm{d}} \mathrm{L} 90 \mathrm{Cl}$ & 0.27 & 0.23 & 0.26 & 0.15 & 0.25 & 0.46 & 0.26 & 0.23 & 0.01 \\
\hline$P_{f p}$ & 0.35 & & & & & & 0.35 & 0.25 & 0.00 \\
\hline$P_{f p} L 90 C l$ & 0.29 & & & & & & 0.31 & 0.17 & 0.00 \\
\hline $\mathrm{Pba}_{\mathrm{ba}}$ & 0.05 & & & & & & & & \\
\hline \multicolumn{10}{|c|}{ DISCRIMINATION STAGE } \\
\hline$P_{d}$ & 0.30 & 0.25 & 0.35 & 0.15 & 0.35 & 0.55 & 0.30 & 0.30 & 0.15 \\
\hline $\mathrm{Pd}_{\mathrm{d}} \mathrm{L} 90 \mathrm{Cl}$ & 0.23 & 0.18 & 0.24 & 0.11 & 0.25 & 0.35 & 0.22 & 0.18 & 0.01 \\
\hline$P_{f p}$ & 0.35 & & & & & & 0.35 & 0.25 & 0.00 \\
\hline$P_{f p} L 90 C l$ & 0.28 & & & & & & 0.30 & 0.15 & 0.00 \\
\hline $\mathrm{Pba}_{\mathrm{ba}}$ & 0.05 & & & & & & & & \\
\hline
\end{tabular}


Table 5. Enhanced GEM-3/pushcart - desert extreme results (USAEC 2005d).

\begin{tabular}{|c|c|c|c|c|c|c|c|c|c|}
\hline \multirow[b]{2}{*}{ Metric } & \multirow[b]{2}{*}{ Overall } & \multirow[b]{2}{*}{ Standard } & \multirow[b]{2}{*}{ Non-standard } & \multicolumn{3}{|c|}{ By Size } & \multicolumn{3}{|c|}{ By Depth, $\mathrm{m}$} \\
\hline & & & & Small & Medium & Large & $<0.3$ & $0.3-<1$ & $>=1$ \\
\hline \multicolumn{10}{|c|}{ RESPONSE STAGE } \\
\hline$P_{d}$ & 0.25 & 0.25 & 0.15 & 0.10 & 0.30 & 0.60 & 0.20 & 0.30 & 0.20 \\
\hline $\mathrm{P}_{\mathrm{d}} \mathrm{L} 90 \mathrm{Cl}$ & 0.18 & 0.21 & 0.10 & 0.06 & 0.18 & 0.43 & 0.13 & 0.22 & 0.02 \\
\hline$P_{f p}$ & 0.40 & & & & & & 0.40 & 0.40 & 0.00 \\
\hline$P_{f p}$ L9OCl & 0.37 & & & & & & 0.37 & 0.32 & 0.00 \\
\hline $\mathrm{Pba}_{\mathrm{ba}}$ & 0.00 & & & & & & & & \\
\hline \multicolumn{10}{|c|}{ DISCRIMINATION STAGE } \\
\hline$P_{d}$ & 0.20 & 0.20 & 0.15 & 0.05 & 0.25 & 0.55 & 0.15 & 0.25 & 0.00 \\
\hline$P_{d} \mathrm{~L} 90 \mathrm{Cl}$ & 0.15 & 0.16 & 0.08 & 0.03 & 0.16 & 0.38 & 0.11 & 0.18 & 0.00 \\
\hline$P_{f p}$ & 0.40 & & & & & & 0.40 & 0.35 & 0.00 \\
\hline$P_{f p} L 90 C l$ & 0.34 & & & & & & 0.35 & 0.25 & 0.00 \\
\hline $\mathrm{Pba}_{\mathrm{ba}}$ & 0.00 & & & & & & & & \\
\hline
\end{tabular}

\section{Limitations of the GEM-3-E}

There are physical limitations to the GEM-3-E affecting its ability to perform as a UXO Detection system. The most significant limitation of this system is the inability to detect targets below a depth of $1 \mathrm{~m}$. This is indicated by a zero value for $P_{d}$ in Tables 2 to 5 when targets were deeper than $1 \mathrm{~m}$, which was the threshold selected by this study. The durability of some system components such as the nylon bolts holding the wheels to this cart could limit the use of this system for operational site characterization activities.

The 8-lb shot at the depth of $0.2 \mathrm{~m}$ was used to analysis the peak distance, in-phase, quadrature, and combined SNR for the enhanced GEM-3-E/pushcart (see Table 6). 
Table 6. Analysis of 8-pound shot at depth $=0.2 \mathrm{ft}$

\begin{tabular}{|c|c|c|c|c|c|c|}
\hline \multirow[b]{2}{*}{$\begin{array}{l}\text { Target } \\
\text { ID }\end{array}$} & \multirow[b]{2}{*}{$\begin{array}{l}\text { Depth, } \\
\mathrm{ft}\end{array}$} & \multirow{2}{*}{$\begin{array}{l}\text { Orientation } \\
\text { AZ/deg } \\
\text { Inclination }\end{array}$} & \multicolumn{4}{|c|}{ GEM-3-E } \\
\hline & & & $\begin{array}{l}\text { Peak Dist } \\
\text { from UXO }\end{array}$ & $\begin{array}{l}\text { In-phase } \\
\text { Sum SNR }\end{array}$ & $\begin{array}{l}\text { Quadrature } \\
\text { Sum SNR }\end{array}$ & $\begin{array}{l}\text { Comb } \\
\text { SNR }\end{array}$ \\
\hline 53 & 0.2 & & 0.087464 & 31.86329 & 24.99054 & 31.02864 \\
\hline 66 & 0.2 & & 0.01456 & 31.51891 & 24.71825 & 30.70044 \\
\hline 79 & 0.91 & & 0.024698 & 30.06215 & 24.01624 & 29.438 \\
\hline 92 & 0.2 & & 0.04653 & 31.53488 & 25.13702 & 30.81681 \\
\hline 97 & 0.2 & & 0.120934 & 31.57845 & 24.44336 & 30.68479 \\
\hline 104 & 0.2 & & 0.039825 & 31.92801 & 24.79675 & 31.0329 \\
\hline 127 & 0.2 & 0 & 3716446 & 13.38036 & 18.54165 & 19.18183 \\
\hline 128 & 0.2 & 0 & 3716444 & 14.41425 & 17.26715 & 18.42095 \\
\hline 129 & 0.2 & 0 & 3716442 & 10.49395 & 15.54625 & 16.2008 \\
\hline 130 & 0.2 & 0 & 3716440 & 12.68228 & 17.30194 & 18.13758 \\
\hline 131 & 0.2 & 0 & 3716438 & 10.7166 & 12.42445 & 14.07909 \\
\hline 132 & 0.2 & 0 & 3716436 & 13.91148 & 13.28757 & 15.82933 \\
\hline 133 & 0.2 & 0 & 3716434 & 12.16211 & 9.498167 & 12.87845 \\
\hline 134 & 0.2 & 0 & 0.055543 & 30.50791 & 24.25529 & 29.82744 \\
\hline 135 & 0.2 & 0 & 0.137179 & 29.95804 & 24.63073 & 29.54032 \\
\hline 136 & 0.2 & 0 & 0.031623 & 31.35429 & 24.90461 & 30.62253 \\
\hline 137 & 0.2 & 0 & 0.079812 & 30.04517 & 24.97686 & 29.71143 \\
\hline 138 & 0.2 & 0 & 3716424 & 13.34349 & 13.87887 & 15.79162 \\
\hline 139 & 0.2 & 0 & 0.122385 & 28.00838 & 24.14625 & 28.09939 \\
\hline 140 & 0.2 & 0 & 0.022 & 26.70898 & 23.29003 & 26.98172 \\
\hline 141 & 0.2 & 0 & 0.101597 & 28.89059 & 24.54164 & 28.79879 \\
\hline 142 & 0.2 & 0 & 0.10538 & 29.56216 & 24.48269 & 29.22587 \\
\hline 143 & 0.2 & 0 & 0.257029 & 29.28031 & 24.45758 & 29.02748 \\
\hline 144 & 0.2 & 0 & 0.194487 & 28.80531 & 23.79073 & 28.48828 \\
\hline 145 & 0.2 & 0 & 0.035228 & 30.27916 & 24.73482 & 29.79911 \\
\hline 146 & 0.2 & 0 & 0.04669 & 31.34053 & 25.36079 & 30.73472 \\
\hline 147 & 0.2 & 0 & 0.102956 & 30.22459 & 24.37669 & 29.65474 \\
\hline 148 & 0.2 & 0 & 0.171919 & 28.79066 & 22.92465 & 28.22034 \\
\hline 149 & 0.2 & 0 & 0.040311 & 28.88443 & 24.17345 & 28.66797 \\
\hline 150 & 0.2 & 0 & 0.013928 & 27.4926 & 22.76691 & 27.27237 \\
\hline 151 & 0.2 & 0 & 0.04826 & 29.0276 & 24.21302 & 28.78207 \\
\hline 152 & 0.2 & 0 & 0.056321 & 29.03179 & 22.24398 & 28.21863 \\
\hline 153 & 0.2 & 0 & 0.10412 & 29.10857 & 24.29503 & 28.85872 \\
\hline 154 & 0.2 & 0 & 0.110725 & 29.37896 & 24.91848 & 29.25035 \\
\hline 155 & 0.2 & 0 & 0.07267 & 27.47786 & 19.8246 & 26.47266 \\
\hline 156 & 0.2 & 0 & 0.049729 & 31.12196 & 24.17616 & 30.27264 \\
\hline 157 & 0.2 & 0 & 0.041049 & 31.05144 & 23.43314 & 30.05156 \\
\hline
\end{tabular}




\begin{tabular}{|c|c|c|c|c|c|c|}
\hline \multirow[b]{2}{*}{$\begin{array}{l}\text { Target } \\
\text { ID }\end{array}$} & \multirow[b]{2}{*}{$\begin{array}{l}\text { Depth, } \\
\mathrm{ft}\end{array}$} & \multirow{2}{*}{$\begin{array}{l}\text { Orientation } \\
\text { AZ/deg } \\
\text { Inclination }\end{array}$} & \multicolumn{4}{|c|}{ GEM-3-E } \\
\hline & & & $\begin{array}{l}\text { Peak Dist } \\
\text { from UXO }\end{array}$ & $\begin{array}{l}\text { In-phase } \\
\text { Sum SNR }\end{array}$ & $\begin{array}{l}\text { Quadrature } \\
\text { Sum SNR }\end{array}$ & $\begin{array}{l}\text { Comb } \\
\text { SNR }\end{array}$ \\
\hline 158 & 0.2 & 0 & 0.063325 & 29.61737 & 22.09354 & 28.63739 \\
\hline 159 & 0.2 & 0 & 0.116932 & 27.08156 & 22.67856 & 26.97344 \\
\hline 160 & 0.2 & 0 & 0.164469 & 30.05108 & 23.04822 & 29.18544 \\
\hline 161 & 0.2 & 0 & 0.066068 & 29.78682 & 24.11576 & 29.26732 \\
\hline 162 & 0.2 & 0 & 0.211967 & 26.41429 & 20.13042 & 25.72721 \\
\hline 163 & 0.2 & 0 & 0.155242 & 27.84577 & 22.81244 & 27.5233 \\
\hline 164 & 0.2 & 0 & 0.118186 & 28.82265 & 24.20454 & 28.63654 \\
\hline 165 & 0.2 & 0 & 0.154984 & 30.5609 & 24.96163 & 30.06182 \\
\hline 166 & 0.2 & 0 & 0.126874 & 30.45853 & 24.10934 & 29.75284 \\
\hline 167 & 0.2 & 0 & 0.106301 & 30.63624 & 24.19476 & 29.91074 \\
\hline 168 & 0.2 & 0 & 0.040311 & 31.06528 & 24.64359 & 30.34083 \\
\hline 169 & 0.2 & 0 & 0.080156 & 31.01174 & 24.54525 & 30.27713 \\
\hline 170 & 0.2 & 0 & 0.072062 & 31.39049 & 26.181 & 31.01825 \\
\hline 171 & 0.2 & 0 & 0.049204 & 30.75433 & 22.9598 & 29.72172 \\
\hline 172 & 0.2 & 0 & 0.301166 & 31.53956 & 25.20855 & 30.84045 \\
\hline 173 & 0.2 & 0 & 0.211244 & 32.88047 & 25.66681 & 31.96812 \\
\hline 174 & 0.2 & 0 & 0.232691 & 32.69676 & 26.16131 & 31.94477 \\
\hline 175 & 0.2 & 0 & 0.127781 & 31.3816 & 24.94753 & 30.6537 \\
\hline 176 & 0.2 & 0 & 0.075472 & 30.5903 & 24.0323 & 29.83373 \\
\hline 177 & 0.2 & 0 & 0.244884 & 32.45668 & 25.80035 & 31.67358 \\
\hline 178 & 0.2 & 0 & 0.110277 & 32.95354 & 26.42905 & 32.20314 \\
\hline 179 & 0.2 & 0 & 0.19598 & 31.08532 & 24.73633 & 30.37979 \\
\hline 180 & 0.2 & 0 & 0.217789 & 31.91833 & 24.7834 & 31.02254 \\
\hline 181 & 0.2 & 0 & 0.129449 & 31.85146 & 25.90419 & 31.25327 \\
\hline 182 & 0.2 & 0 & 0.068264 & 32.48545 & 26.3123 & 31.82576 \\
\hline
\end{tabular}




\title{
7 Conclusions
}

\author{
Conclusions are as follows:
}

1. The ERDC team experienced down time due to problems with the GEM-3-E pushcart. The wheel became dislodged repeatedly from the pushcart during operation. Additional manpower was used to assist the mobility of the cart. Ropes were attached to the side of the pushcart to take the weight off of the wheel and allow site survey activities to continue even in very difficult terrain. The fragility of the system could limit the use of this system for operational site characterization activities.

2. Four personnel were required to operate the GEM-3-E due to the axle failures. With improvements to the functionality of the pushcart, three personnel should be able to operate the GEM-3-E pushcart system.

3. The most significant limitation of the GEM-3-E was the inability to detect targets below a depth of $1 \mathrm{~m}$. This is indicated by a zero value for $\mathrm{P}_{\mathrm{d}}$, in Tables 3 and 4 , when the targets were located deeper than $1 \mathrm{~m}$, which was the threshold selected by this study.

4. With respect to the calibration lane data, the in-phase signal showed an improvement by the GEM-3-E. However, the quadrature did not show any clear improvement in this enhanced model. These results may be due to the GEM-3-E calibration favoring the in-phase. The magnitude of the in-phase response for the GEM-3-E was three times greater than the magnitude of the quadrature. The ferrite core calibration was performed and the in-phase response was level, indicating that the in-phase was properly calibrated for this system. However, the q-coil calibration was not performed. This calibration would align the quadrature calibration with respect to the in-phase. When extreme level imbalances are detected, the systems must be returned to the manufacturer for q-coil calibration and level balancing. 


\section{Recommendations}

Recommendations are as follows:

1. During future use of the GEM-3-E, the assumption should not be made that, if the in-phase was calibrated, the quadrature was balanced with respect to thein-phase.

2. The amplitude comparison of the calibration lane data should be made to compensate for the poorly balanced GEM-3-E.

3. The pushcart should be ruggedized for field survey applications.

4. The GEM-3 system should be used for shallow depth ( $<1 \mathrm{~m})$ UXO detection and discrimination applications. 


\section{References}

Bennett, H. H., T. A. DeMoss, M. P. Fields, R. A Goodson, and J . C. Morgan. 2006. Aberdeen Proving Ground GEM-3 data collection. ERDC/ EL TR-06-11. Vicksburg, MS: U.S. Army Engineer Research and Development Center.

Cespedes, E. R. 2001. Advanced UXO detection/ discrimination technology demonstration - U.S. Army J efferson Proving Ground, Madison, Indiana. ERDC/ EL TR-01-20. Vicksburg, MS: U.S. Army Engineer Research and Development Center.

Miller, J., T. Bell, D. Keiswetter, and D. Wright. 2001. Feature-based characterization of UXO-like targets using broadband electromagnetic induction. In UXO Forum 2001 Proceedings, New Orleans, LA.

U.S. Army Engineer Research and Development Center (ERDC). 2002. Analysis of GEM-3 data from the advanced UXO detection/ discrimination technology demonstration - U.S. Army J efferson Proving Ground, Madison, Indiana. ERDC/ EL TR-02-25. Vicksburg, MS.

U.S. Army Environmental Center (USAEC). 2005a. Standardized UXO technology demonstration site blind grid scoring record no. 134. Aberdeen Proving Ground, MD.

. 2005b. Standardized UXO technology demonstration site open field scoring record no. 135. Aberdeen Proving Ground, MD.

. 2005c. Standardized UXO technology demonstration site moguls scoring record no. 136. Aberdeen Proving Ground, MD.

. 2005d. Standardized UXO technology demonstration site desert extreme scoring record no. 509. Aberdeen Proving Ground, MD.

Won, I. J ., D. A. Keiswetter, D. R. Hanson, E. Novikova, and T. M. Hall. 1997. GEM-3: A monostatic broadband electromagnetic induction sensor. J ournal of Environmental and Engineering Geophysics 2(1):53-64. 


\section{Appendix A: Dig List}

\begin{tabular}{|c|c|c|c|c|c|c|c|c|}
\hline \multirow{3}{*}{$\begin{array}{l}\text { Target } \\
\text { ID } \\
1\end{array}$} & \multirow{3}{*}{\begin{tabular}{|l|} 
Description \\
12 gauge $30-\mathrm{cm}$ loop
\end{tabular}} & \multirow{3}{*}{\begin{tabular}{|l|} 
Depth \\
0.25
\end{tabular}} & \multirow{2}{*}{\multicolumn{2}{|c|}{$\begin{array}{l}\text { Orientation } \\
\text { az/deg } \\
\text { Inclination }\end{array}$}} & \multicolumn{4}{|c|}{ GEM-3-E } \\
\hline & & & & & \multirow{2}{*}{\begin{tabular}{|l|}
$\begin{array}{l}\text { Peak Dist } \\
\text { from UXO }\end{array}$ \\
0.045398 \\
\end{tabular}} & \multirow{2}{*}{\begin{tabular}{|l|}
$\begin{array}{l}\text { In-phase } \\
\text { Sum SNR }\end{array}$ \\
46.04636 \\
\end{tabular}} & \multirow{2}{*}{\begin{tabular}{|l|}
$\begin{array}{l}\text { Quadrature } \\
\text { Sum SNR }\end{array}$ \\
35.30383 \\
\end{tabular}} & \multirow{2}{*}{ 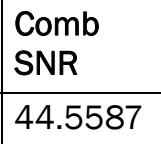 } \\
\hline & & & $n / a$ & 0 & & & & \\
\hline 2 & 12 gauge $30-\mathrm{cm}$ loop & 0.25 & $0 \mathrm{az}$ & 90 & 0.30566 & 25.98845 & 20.31314 & 25.48962 \\
\hline 3 & 12 gauge $15-\mathrm{cm}$ loop & 0.25 & $n / a$ & 0 & 0.267606 & 29.71297 & 19.62567 & 28.30872 \\
\hline 4 & 12 gauge $15-\mathrm{cm}$ loop & 0.25 & $0 \mathrm{az}$ & 90 & 0.243288 & 17.2155 & 7.825406 & 15.91559 \\
\hline 5 & 16 gauge $30-\mathrm{cm}$ loop & 0.25 & $n / a$ & 0 & 0.173566 & 43.00444 & 34.43607 & 41.82364 \\
\hline 6 & 16 gauge $30-\mathrm{cm}$ loop & 0.25 & $0 \mathrm{az}$ & 90 & 0.210281 & 25.23585 & 17.97142 & 24.31616 \\
\hline 7 & 16 gauge $15-\mathrm{cm}$ loop & 0.25 & $n / a$ & 0 & 0.028653 & 27.37665 & 18.04112 & 26.07256 \\
\hline 8 & 16 gauge $15-\mathrm{cm}$ loop & 0.25 & $0 \mathrm{az}$ & 90 & 0.307002 & 10.81603 & 9.568593 & 12.26114 \\
\hline 9 & 12-lb shot & 0.5 & $n / a$ & 0 & 0.145121 & 11.84672 & 14.1521 & 15.36613 \\
\hline 10 & 12-lb shot & 1 & $n / a$ & 0 & 0.155602 & 1.284211 & 8.26164 & 8.791267 \\
\hline 11 & 12-lb shot & 1.5 & $n / a$ & 0 & 0.185777 & 7.392535 & 5.753826 & 9.069432 \\
\hline 12 & 12-lb shot & 2 & $n / a$ & 0 & 0.188298 & 8.298423 & 9.998932 & 11.89752 \\
\hline 13 & 18 gauge $30-\mathrm{cm}$ loop & 0.25 & n/a & 0 & 0.07433 & 41.13254 & 32.75551 & 39.98567 \\
\hline 14 & 18 gauge $30-\mathrm{cm}$ loop & 0.25 & $0 \mathrm{az}$ & 90 & 0.334631 & 21.02256 & 19.35848 & 22.10758 \\
\hline 15 & 18 gauge $15-\mathrm{cm}$ loop & 0.25 & $n / a$ & 0 & 0.264518 & 26.20331 & 16.6502 & 24.87222 \\
\hline 16 & 18 gauge $15-\mathrm{cm}$ loop & 0.25 & $0 \mathrm{az}$ & 90 & 0.054424 & 13.07343 & 7.19131 & 12.57323 \\
\hline 17 & 20 gauge $30-\mathrm{cm}$ loop & 0.25 & $n / a$ & 0 & 0.210155 & 38.57211 & 32.41523 & 37.91659 \\
\hline 18 & 20 gauge $30-\mathrm{cm}$ loop & 0.25 & $0 \mathrm{az}$ & 90 & 0.314033 & 19.6117 & 16.17238 & 19.87133 \\
\hline 19 & 20 gauge $15-\mathrm{cm}$ loop & 0.25 & $n / a$ & 0 & 0.023409 & 23.69284 & 16.31521 & 22.74466 \\
\hline 20 & 20 gauge $15-\mathrm{cm}$ loop & 0.25 & $0 \mathrm{az}$ & 90 & 0.242244 & 6.977257 & 10.09289 & 11.43448 \\
\hline 21 & 20-mm M55 & 0.1 & $0 \mathrm{az}$ & 45 & 0.219021 & 8.084613 & 8.58289 & 10.61786 \\
\hline 22 & 20-mm M55 & 0.1 & $0 \mathrm{az}$ & -45 & 0.129124 & 9.012208 & 8.06082 & 10.79043 \\
\hline 23 & 20-mm M55 & 0.1 & $n / a$ & 90 & 0.328694 & 8.210545 & 7.472871 & 10.38011 \\
\hline 24 & 20-mm M55 & 0.1 & $n / a$ & -90 & 0.224129 & 7.467432 & 8.502005 & 10.39216 \\
\hline 25 & 20-mm M55 & 0.2 & $0 \mathrm{az}$ & 0 & 0.042154 & 5.947251 & 9.244053 & 10.41961 \\
\hline 26 & 20-mm M55 & 0.2 & 180az & 0 & 0.240002 & 1.044412 & 8.666164 & 9.039016 \\
\hline 27 & 8-Ib shot & 0.2 & & & 0.102825 & 31.91126 & 25.40819 & 31.16716 \\
\hline 28 & 40-mm MK II & 0.15 & $0 \mathrm{az}$ & 45 & 0.210152 & 19.82306 & 20.28555 & 22.10005 \\
\hline 29 & 40-mm MK II & 0.15 & $0 \mathrm{az}$ & -45 & 0.103586 & 19.2748 & 18.27415 & 20.68744 \\
\hline 30 & 40-mm MK II & 0.15 & $n / a$ & 90 & 0.044553 & 22.40968 & 23.04314 & 24.79004 \\
\hline 31 & 40-mm MK II & 0.15 & $n / a$ & -90 & 0.168048 & 16.18526 & 17.35594 & 18.92387 \\
\hline 32 & 40-mm MK II & 0.3 & $0 \mathrm{az}$ & 0 & 0.075313 & 9.906054 & 6.695668 & 10.25782 \\
\hline 33 & 40-mm MK II & 0.3 & 180az & 0 & 0.057871 & 11.54662 & 9.57904 & 12.48743 \\
\hline 34 & 40-mm M385 & 0.1 & $0 \mathrm{az}$ & 45 & 0.033734 & 20.93221 & 11.98803 & 19.72518 \\
\hline
\end{tabular}




\begin{tabular}{|c|c|c|c|c|c|c|c|c|}
\hline \multirow{3}{*}{$\begin{array}{l}\begin{array}{l}\text { Target } \\
\text { ID }\end{array} \\
35\end{array}$} & \multirow{3}{*}{\begin{tabular}{|l|} 
Description \\
40-mm M385
\end{tabular}} & \multirow{3}{*}{\begin{tabular}{|l|} 
Depth \\
0.1
\end{tabular}} & \multirow{2}{*}{\multicolumn{2}{|c|}{$\begin{array}{l}\text { Orientation } \\
\text { az/deg } \\
\text { Inclination }\end{array}$}} & \multicolumn{4}{|c|}{ GEM-3-E } \\
\hline & & & & & \multirow{2}{*}{\begin{tabular}{|l}
$\begin{array}{l}\text { Peak Dist } \\
\text { from UXO }\end{array}$ \\
0.034059
\end{tabular}} & \multirow{2}{*}{\begin{tabular}{|l|}
$\begin{array}{l}\text { In-phase } \\
\text { Sum SNR }\end{array}$ \\
19.95184 \\
\end{tabular}} & \multirow{2}{*}{\begin{tabular}{|l|}
$\begin{array}{l}\text { Quadrature } \\
\text { Sum SNR }\end{array}$ \\
14.12924 \\
\end{tabular}} & \multirow{2}{*}{\begin{tabular}{|l|}
$\begin{array}{l}\text { Comb } \\
\text { SNR }\end{array}$ \\
19.68177
\end{tabular}} \\
\hline & & & $0 \mathrm{az}$ & -45 & & & & \\
\hline 36 & 40-mm M385 & 0.1 & $\mathrm{n} / \mathrm{a}$ & 90 & 0.277872 & 18.81413 & 5.905902 & 17.14277 \\
\hline 37 & 40-mm M385 & 0.1 & $\mathrm{n} / \mathrm{a}$ & -90 & 0.043658 & 18.48009 & 3.358724 & 16.69955 \\
\hline 38 & 40-mm M385 & 0.2 & $0 \mathrm{az}$ & 0 & 0.267152 & 16.49819 & 4.450576 & 15.05567 \\
\hline 39 & 40-mm M385 & 0.2 & 180az & 0 & 0.074243 & 11.88517 & 9.233161 & 12.51536 \\
\hline 40 & 8-Ib shot & 0.2 & & & 0.110887 & 32.08488 & 25.13296 & 31.23101 \\
\hline 41 & M42 & 0.15 & $0 \mathrm{az}$ & 45 & 0.112872 & 15.95128 & 14.09265 & 16.92564 \\
\hline 42 & M42 & 0.15 & $0 \mathrm{az}$ & -45 & 0.082006 & 17.48002 & 11.79465 & 16.97414 \\
\hline 43 & M42 & 0.15 & $n / a$ & 90 & 0.141834 & 17.87633 & 15.66757 & 18.67429 \\
\hline 44 & M42 & 0.15 & $n / a$ & -90 & 0.184201 & 16.94904 & 14.69536 & \begin{tabular}{|l|}
17.7427 \\
\end{tabular} \\
\hline 45 & M42 & 0.35 & $0 \mathrm{az}$ & 0 & 0.098494 & 5.381633 & 8.300152 & 9.78852 \\
\hline 46 & M42 & 0.35 & 180az & 0 & 0.143126 & 6.505894 & 5.691042 & 8.203534 \\
\hline 47 & BLU-26 & 0.1 & $n / a$ & 0 & 0.074411 & 21.92956 & 19.02954 & 22.40914 \\
\hline 48 & BLU-26 & 0.1 & $n / a$ & 0 & 0.073498 & 20.75514 & 18.56464 & 21.59617 \\
\hline 49 & BLU-26 & 0.1 & $n / a$ & 0 & 0.331183 & 20.59031 & 17.68289 & 21.11658 \\
\hline 50 & BLU-26 & 0.1 & $n / a$ & 0 & 0.15769 & 20.44115 & 17.54554 & 20.94536 \\
\hline 51 & BLU-26 & 0.2 & $n / a$ & 0 & 0.338095 & 14.38264 & 9.966319 & 14.30848 \\
\hline 52 & BLU-26 & 0.2 & $n / a$ & 0 & 0.227035 & 12.67858 & 12.35277 & 14.47585 \\
\hline 53 & 8-Ib shot & 0.2 & & & 0.087464 & 31.86329 & 24.99054 & 31.02864 \\
\hline 54 & BDU-28 & 0.1 & $0 \mathrm{az}$ & 45 & 0.222092 & \begin{tabular}{|l|}
12.37517 \\
\end{tabular} & 12.93892 & 14.71023 \\
\hline 55 & BDU-28 & 0.1 & $0 \mathrm{az}$ & -45 & 0.124326 & 24.64688 & 18.91107 & 24.1146 \\
\hline 56 & BDU-28 & 0.1 & $n / a$ & 90 & 0.124064 & 15.96304 & 11.51392 & 15.88335 \\
\hline 57 & BDU-28 & 0.1 & $n / a$ & -90 & 0.130771 & 27.43487 & 17.7066 & 26.07578 \\
\hline 58 & BDU-28 & 0.2 & $0 \mathrm{az}$ & 0 & 0.02377 & 17.87125 & 14.47749 & 18.21448 \\
\hline 59 & BDU-28 & 0.2 & 180az & 0 & 0.079057 & 19.29123 & 9.920792 & 17.99131 \\
\hline 60 & 57-mm M86 & 0.4 & $0 \mathrm{az}$ & 45 & 0.032757 & 11.07676 & 14.06922 & 15.12025 \\
\hline 61 & 57-mm M86 & 0.4 & $0 \mathrm{az}$ & -45 & 0.10959 & 8.537169 & 6.916072 & 9.638531 \\
\hline 62 & 57-mm M86 & 0.4 & $n / a$ & 90 & 0.27927 & 9.562678 & 14.85687 & 15.43515 \\
\hline 63 & 57-mm M86 & 0.4 & $n / a$ & -90 & 0.318157 & 10.15905 & 10.54775 & 12.66133 \\
\hline 64 & 57-mm M86 & 0.91 & $0 \mathrm{az}$ & 0 & 0.252343 & 9.375226 & 10.43424 & 12.27657 \\
\hline 65 & 57-mm M86 & 0.91 & 180az & 0 & 0.054708 & 8.8068 & -2.05006 & 7.363422 \\
\hline 66 & 8-Ib shot & 0.2 & & & 0.01456 & 31.51891 & 24.71825 & 30.70044 \\
\hline 67 & MK 118 Rockeye & 0.3 & $0 \mathrm{az}$ & 45 & 0.339796 & 7.334621 & -4.38743 & 6.061586 \\
\hline 68 & MK 118 Rockeye & 0.3 & $0 \mathrm{az}$ & -45 & 0.153056 & 12.70916 & 8.772865 & 12.8205 \\
\hline 69 & MK 118 Rockeye & 0.3 & $n / a$ & 90 & 0.212984 & -0.65331 & 9.468533 & 9.588865 \\
\hline 70 & MK 118 Rockeye & 0.3 & $n / a$ & -90 & 0.299862 & 7.175468 & 7.181343 & 9.309465 \\
\hline 71 & MK 118 Rockeye & 0.6 & $0 \mathrm{az}$ & 0 & 0.308058 & 2.69895 & 2.221935 & 4.788337 \\
\hline 72 & MK 118 Rockeye & 0.6 & 180az & 0 & 0.150083 & 5.318536 & -0.15237 & 5.54576 \\
\hline
\end{tabular}




\begin{tabular}{|c|c|c|c|c|c|c|c|c|}
\hline \multirow{3}{*}{$\begin{array}{l}\text { Target } \\
\text { ID }\end{array}$} & \multirow{3}{*}{\begin{tabular}{|l|} 
Description \\
$60-\mathrm{mm}$ M49A3 \\
\end{tabular}} & \multirow{3}{*}{\begin{tabular}{|l|} 
Depth \\
0.4
\end{tabular}} & \multirow{2}{*}{\multicolumn{2}{|c|}{$\begin{array}{l}\text { Orientation } \\
\text { az/deg } \\
\text { Inclination }\end{array}$}} & \multicolumn{4}{|c|}{ GEM-3-E } \\
\hline & & & & & \multirow{2}{*}{\begin{tabular}{|l}
$\begin{array}{l}\text { Peak Dist } \\
\text { from UXO }\end{array}$ \\
0.05021 \\
\end{tabular}} & \multirow{2}{*}{\begin{tabular}{|l|}
$\begin{array}{l}\text { In-phase } \\
\text { Sum SNR }\end{array}$ \\
15.31714 \\
\end{tabular}} & \multirow{2}{*}{$\begin{array}{l}\text { Quadrature } \\
\text { Sum SNR } \\
11.85163 \\
\end{array}$} & \multirow{2}{*}{\begin{tabular}{|l|l}
$\begin{array}{l}\text { Comb } \\
\text { SNR }\end{array}$ \\
15.57462
\end{tabular}} \\
\hline & & & $0 \mathrm{az}$ & 45 & & & & \\
\hline 74 & 60-mm M49A3 & 0.4 & $0 \mathrm{az}$ & -45 & 0.201122 & 8.721837 & 7.600725 & 10.32679 \\
\hline 75 & 60-mm M49A3 & 0.4 & $n / a$ & 90 & 0.270326 & 9.043808 & 14.49703 & 15.11909 \\
\hline 76 & 60-mm M49A3 & 0.4 & $n / a$ & -90 & 0.296709 & 5.577736 & 8.867345 & 10.02102 \\
\hline 77 & 60-mm M49A3 & 0.4 & $0 \mathrm{az}$ & 0 & 0.139445 & 7.811353 & 9.453322 & 11.23003 \\
\hline 78 & 60-mm M49A3 & 0.91 & 180az & 0 & 0.062177 & 11.81996 & 12.41007 & 14.22995 \\
\hline 79 & 8-Ib shot & 0.91 & & & 0.024698 & 30.06215 & 24.01624 & 29.438 \\
\hline 80 & 81-mm M374 & 0.5 & $0 \mathrm{az}$ & 45 & 0.151476 & 7.568478 & 8.768149 & 10.35434 \\
\hline 81 & 81-mm M374 & 0.5 & $0 \mathrm{az}$ & -45 & 0.122201 & 14.31739 & 13.53407 & 15.85759 \\
\hline 82 & 81-mm M374 & 0.5 & $n / a$ & 90 & 0.300148 & 5.119194 & 6.461851 & 8.378792 \\
\hline 83 & 81-mm M374 & 0.5 & $\mathrm{n} / \mathrm{a}$ & -90 & 0.213354 & 11.02848 & 10.11056 & 12.58131 \\
\hline 84 & 81-mm M374 & 1.5 & $0 \mathrm{az}$ & 0 & 0.083235 & 0.672626 & 7.373792 & 8.020512 \\
\hline 85 & 81-mm M374 & 1.5 & 180az & 0 & 0.180278 & 10.43011 & 5.137051 & 10.49624 \\
\hline 86 & $2.75 \mathrm{M} 230$ & 0.5 & $0 \mathrm{az}$ & 45 & 0.080062 & 18.93994 & 17.44359 & 20.1231 \\
\hline 87 & $2.75 \mathrm{M} 230$ & 0.5 & $0 \mathrm{az}$ & -45 & 0.1822 & 13.1616 & 13.80518 & 15.70239 \\
\hline 88 & $2.75 \mathrm{M} 230$ & 0.5 & $n / a$ & 90 & 0.193342 & 18.71731 & 19.35539 & 21.1016 \\
\hline 89 & $2.75 \mathrm{M} 230$ & 0.5 & $\mathrm{n} / \mathrm{a}$ & -90 & 0.256164 & 16.61077 & 12.28417 & 16.55109 \\
\hline 90 & $2.75 \mathrm{M} 230$ & 1.2 & $0 \mathrm{az}$ & 0 & 0.172351 & 7.882354 & 2.095017 & 7.770577 \\
\hline 91 & $2.75 \mathrm{M} 230$ & 1.2 & 180az & 0 & 0.243731 & 5.762016 & 3.986436 & 7.332817 \\
\hline 92 & 8-Ib shot & 0.2 & & & 0.04653 & 31.53488 & 25.13702 & 30.81681 \\
\hline 93 & 60-mm M49A3/No Clutter & 0.25 & $0 \mathrm{az}$ & 0 & 0.174771 & 21.90079 & 18.05243 & 22.00552 \\
\hline 94 & 60-mm M49A3/Low Clutter & 0.25 & $0 \mathrm{az}$ & 0 & 0.158493 & 32.83856 & 26.63522 & 32.22475 \\
\hline 95 & 60-mm M49A3/Medium Clutter & 0.25 & $0 \mathrm{az}$ & 0 & 0.183992 & 36.55491 & 28.55443 & 35.4946 \\
\hline 96 & 60-mm M49A3/High Clutter & 0.25 & $0 \mathrm{az}$ & 0 & 0.102883 & 38.4628 & 30.93983 & 37.4892 \\
\hline 97 & 8-Ib shot & 0.2 & & & 0.120934 & 31.57845 & 24.44336 & 30.68479 \\
\hline 98 & M75 & 0.15 & $0 \mathrm{az}$ & & 0.08956 & 23.13705 & 18.65952 & 23.00562 \\
\hline 99 & M75 & 0.15 & $0 \mathrm{az}$ & & 0.034015 & 23.72822 & 19.26538 & 23.59466 \\
\hline 100 & M75 & 0.15 & $n / a$ & & 0.169499 & 21.57682 & 16.33662 & 21.1875 \\
\hline 101 & M75 & 0.15 & $n / a$ & & 0.109385 & 23.92078 & 20.57377 & 24.21439 \\
\hline 102 & M75 & 0.3 & $0 \mathrm{az}$ & & 0.157918 & 15.29115 & 11.01641 & 15.2458 \\
\hline 103 & M75 & 0.3 & $180 \mathrm{az}$ & & 0.040497 & 13.56248 & 14.58601 & 16.30273 \\
\hline 104 & 8-Ib shot & 0.2 & & & 0.039825 & 31.92801 & 24.79675 & 31.0329 \\
\hline 105 & $30-\mathrm{cm}$ steel plate & 0.5 & $\mathrm{n} / \mathrm{a}$ & 0 & 0.037014 & 29.52633 & 23.50995 & 28.96162 \\
\hline 106 & $30-\mathrm{cm}$ steel plate & 1 & $\mathrm{n} / \mathrm{a}$ & 0 & 0.288368 & 11.76831 & 9.058465 & 12.53851 \\
\hline 107 & $60-\mathrm{cm}$ steel plate & 0.5 & $n / a$ & 0 & 0.1236 & 51.16052 & 38.10414 & 49.46719 \\
\hline 108 & 60-cm steel plate & 1 & $\mathrm{n} / \mathrm{a}$ & 0 & 0.121758 & 28.26969 & 16.86764 & 26.71586 \\
\hline 109 & 105-mm M456 heat & 0.4 & $0 \mathrm{az}$ & 45 & 0.105513 & 20.77578 & 12.11541 & 19.75219 \\
\hline 110 & 105-mm M456 heat & 0.4 & $0 \mathrm{az}$ & -45 & 0.251311 & 20.01344 & 15.94048 & 20.06212 \\
\hline
\end{tabular}




\begin{tabular}{|c|c|c|c|c|c|c|c|c|}
\hline \multirow{3}{*}{$\begin{array}{l}\begin{array}{l}\text { Target } \\
\text { ID }\end{array} \\
111\end{array}$} & \multirow{3}{*}{\begin{tabular}{|l} 
Description \\
105-mm M456 heat \\
\end{tabular}} & \multirow{3}{*}{\begin{tabular}{|l|} 
Depth \\
0.4
\end{tabular}} & \multirow{2}{*}{\multicolumn{2}{|c|}{$\begin{array}{l}\text { Orientation } \\
\text { az/deg } \\
\text { Inclination }\end{array}$}} & \multicolumn{4}{|c|}{ GEM-3-E } \\
\hline & & & & & \multirow{2}{*}{\begin{tabular}{|l}
$\begin{array}{l}\text { Peak Dist } \\
\text { from UXO }\end{array}$ \\
0.247342 \\
\end{tabular}} & \multirow{2}{*}{\begin{tabular}{|l|}
$\begin{array}{l}\text { In-phase } \\
\text { Sum SNR }\end{array}$ \\
14.6361 \\
\end{tabular}} & \multirow{2}{*}{\begin{tabular}{|l|}
$\begin{array}{l}\text { Quadrature } \\
\text { Sum SNR }\end{array}$ \\
7.157489 \\
\end{tabular}} & \multirow{2}{*}{\begin{tabular}{|l|}
$\begin{array}{l}\text { Comb } \\
\text { SNR }\end{array}$ \\
13.75047
\end{tabular}} \\
\hline & & & $\mathrm{n} / \mathrm{a}$ & 90 & & & & \\
\hline 112 & 105-mm M456 heat & 0.4 & $\mathrm{n} / \mathrm{a}$ & -90 & 0.090139 & 18.61562 & 17.16469 & 19.81795 \\
\hline 113 & 105-mm M456 heat & 0.8 & $0 \mathrm{az}$ & 0 & 0.116765 & 6.768506 & 10.08564 & 11.06352 \\
\hline 114 & 105-mm M456 heat & 0.8 & 180az & 0 & 0.173289 & 9.391621 & 12.23677 & 13.37074 \\
\hline 115 & 105-mm M60 & 0.4 & $0 \mathrm{az}$ & 45 & 0.24233 & 24.56468 & 20.54948 & 24.60639 \\
\hline 116 & 105-mm M60 & 0.4 & $0 \mathrm{az}$ & -45 & 0.120017 & 22.82583 & 22.33305 & 24.53661 \\
\hline 117 & 105-mm M60 & 0.4 & $\mathrm{n} / \mathrm{a}$ & 90 & 0.154842 & 20.63184 & 19.23866 & 21.87461 \\
\hline 118 & 105-mm M60 & 0.4 & $\mathrm{n} / \mathrm{a}$ & -90 & 0.126779 & 21.57689 & 21.90381 & 23.76039 \\
\hline 119 & 105-mm M60 & 0.8 & $0 \mathrm{az}$ & 0 & 0.144184 & 8.032037 & 10.37852 & 11.59194 \\
\hline 120 & 105-mm M60 & 0.8 & 180az & 0 & 0.100005 & 9.644265 & 8.043313 & 10.78427 \\
\hline 121 & 155-mm M483A1 & 0.75 & $0 \mathrm{az}$ & 45 & 0.254637 & \begin{tabular}{|l|}
15.79475 \\
\end{tabular} & 12.32389 & 16.26553 \\
\hline 122 & 155-mm M483A1 & 0.75 & $0 \mathrm{az}$ & -45 & 0.208543 & 13.78841 & 14.27637 & 16.08517 \\
\hline 123 & 155-mm M483A1 & 0.75 & $n / a$ & 90 & 0.127624 & 20.89539 & 6.286008 & 19.12306 \\
\hline 124 & 155-mm M483A1 & 0.75 & $\mathrm{n} / \mathrm{a}$ & -90 & 0.324692 & 8.330532 & 5.651388 & 9.201432 \\
\hline 125 & 155-mm M483A1 & 1.5 & $0 \mathrm{az}$ & 0 & 0.255314 & 6.996879 & 8.929585 & 10.50084 \\
\hline 126 & 155-mm M483A1 & 1.5 & 180az & 0 & 0.207562 & 9.577828 & 4.395556 & 9.86879 \\
\hline 127 & 8-Ib shot & 0.2 & 0 & & 3716446 & 13.38036 & 18.54165 & 19.18183 \\
\hline 128 & 8-Ib shot & 0.2 & 0 & & 3716444 & 14.41425 & 17.26715 & 18.42095 \\
\hline 129 & 8-Ib shot & 0.2 & 0 & & 3716442 & 10.49395 & 15.54625 & 16.2008 \\
\hline 130 & 8-Ib shot & 0.2 & 0 & & 3716440 & 12.68228 & 17.30194 & 18.13758 \\
\hline 131 & 8-Ib shot & 0.2 & 0 & & 3716438 & 10.7166 & 12.42445 & 14.07909 \\
\hline 132 & 8-Ib shot & 0.2 & 0 & & 3716436 & 13.91148 & 13.28757 & 15.82933 \\
\hline 133 & 8-Ib shot & 0.2 & 0 & & 3716434 & 12.16211 & 9.498167 & 12.87845 \\
\hline 134 & 8-Ib shot & 0.2 & 0 & & 0.055543 & 30.50791 & 24.25529 & 29.82744 \\
\hline 135 & 8-Ib shot & 0.2 & 0 & & 0.137179 & 29.95804 & 24.63073 & 29.54032 \\
\hline 136 & 8-Ib shot & 0.2 & 0 & & 0.031623 & 31.35429 & 24.90461 & 30.62253 \\
\hline 137 & 8-Ib shot & 0.2 & 0 & & 0.079812 & 30.04517 & 24.97686 & 29.71143 \\
\hline 138 & 8-Ib shot & 0.2 & 0 & & 3716424 & 13.34349 & 13.87887 & 15.79162 \\
\hline 139 & 8-Ib shot & 0.2 & 0 & & 0.122385 & 28.00838 & 24.14625 & 28.09939 \\
\hline 140 & 8-Ib shot & 0.2 & 0 & & 0.022 & 26.70898 & 23.29003 & 26.98172 \\
\hline 141 & 8-Ib shot & 0.2 & 0 & & 0.101597 & 28.89059 & 24.54164 & 28.79879 \\
\hline 142 & 8-Ib shot & 0.2 & 0 & & 0.10538 & 29.56216 & 24.48269 & 29.22587 \\
\hline 143 & 8-Ib shot & 0.2 & 0 & & 0.257029 & 29.28031 & 24.45758 & 29.02748 \\
\hline 144 & 8-Ib shot & 0.2 & 0 & & 0.194487 & 28.80531 & 23.79073 & 28.48828 \\
\hline 145 & 8-Ib shot & 0.2 & 0 & & 0.035228 & 30.27916 & 24.73482 & 29.79911 \\
\hline 146 & 8-Ib shot & 0.2 & 0 & & 0.04669 & 31.34053 & 25.36079 & 30.73472 \\
\hline 147 & 8-Ib shot & 0.2 & 0 & & 0.102956 & 30.22459 & 24.37669 & 29.65474 \\
\hline 148 & 8-Ib shot & 0.2 & 0 & & 0.171919 & 28.79066 & 22.92465 & 28.22034 \\
\hline
\end{tabular}




\begin{tabular}{|c|c|c|c|c|c|c|c|}
\hline \multirow[b]{2}{*}{$\begin{array}{l}\text { Target } \\
\text { ID }\end{array}$} & \multirow[b]{2}{*}{ Description } & \multirow[b]{2}{*}{ Depth } & \multirow{2}{*}{$\begin{array}{l}\text { Orientation } \\
\text { az/deg } \\
\text { Inclination }\end{array}$} & \multicolumn{4}{|c|}{ GEM-3-E } \\
\hline & & & & $\begin{array}{l}\text { Peak Dist } \\
\text { from UXO }\end{array}$ & \begin{tabular}{|l|} 
In-phase \\
Sum SNR
\end{tabular} & $\begin{array}{l}\text { Quadrature } \\
\text { Sum SNR }\end{array}$ & $\begin{array}{l}\text { Comb } \\
\text { SNR }\end{array}$ \\
\hline 149 & 8-Ib shot & 0.2 & 0 & 0.040311 & 28.88443 & 24.17345 & 28.66797 \\
\hline 150 & 8-Ib shot & 0.2 & 0 & 0.013928 & 27.4926 & 22.76691 & 27.27237 \\
\hline 151 & 8-Ib shot & 0.2 & 0 & 0.04826 & 29.0276 & 24.21302 & 28.78207 \\
\hline 152 & 8-Ib shot & 0.2 & 0 & 0.056321 & 29.03179 & 22.24398 & 28.21863 \\
\hline 153 & 8-Ib shot & 0.2 & 0 & 0.10412 & 29.10857 & 24.29503 & 28.85872 \\
\hline 154 & 8-Ib shot & 0.2 & 0 & 0.110725 & 29.37896 & 24.91848 & 29.25035 \\
\hline 155 & 8-Ib shot & 0.2 & 0 & 0.07267 & 27.47786 & 19.8246 & 26.47266 \\
\hline 156 & 8-Ib shot & 0.2 & 0 & 0.049729 & 31.12196 & 24.17616 & 30.27264 \\
\hline 157 & 8-Ib shot & 0.2 & 0 & 0.041049 & 31.05144 & 23.43314 & 30.05156 \\
\hline 158 & 8-Ib shot & 0.2 & 0 & 0.063325 & $\mid 29.61737$ & 22.09354 & 28.63739 \\
\hline 159 & 8-Ib shot & 0.2 & 0 & 0.116932 & 27.08156 & 22.67856 & 26.97344 \\
\hline 160 & 8-Ib shot & 0.2 & 0 & 0.164469 & 30.05108 & 23.04822 & 29.18544 \\
\hline 161 & 8-Ib shot & 0.2 & 0 & 0.066068 & 29.78682 & 24.11576 & 29.26732 \\
\hline 162 & 8-Ib shot & 0.2 & 0 & 0.211967 & 26.41429 & 20.13042 & 25.72721 \\
\hline 163 & 8-Ib shot & 0.2 & 0 & 0.155242 & 27.84577 & 22.81244 & 27.5233 \\
\hline 164 & 8-Ib shot & 0.2 & 0 & 0.118186 & 28.82265 & 24.20454 & 28.63654 \\
\hline 165 & 8-Ib shot & 0.2 & 0 & 0.154984 & 30.5609 & 24.96163 & 30.06182 \\
\hline 166 & 8-Ib shot & 0.2 & 0 & 0.126874 & 30.45853 & 24.10934 & 29.75284 \\
\hline 167 & 8-Ib shot & 0.2 & 0 & 0.106301 & 30.63624 & 24.19476 & 29.91074 \\
\hline 168 & 8-Ib shot & 0.2 & 0 & 0.040311 & 31.06528 & 24.64359 & 30.34083 \\
\hline 169 & 8-Ib shot & 0.2 & 0 & 0.080156 & 31.01174 & 24.54525 & 30.27713 \\
\hline 170 & 8-Ib shot & 0.2 & 0 & 0.072062 & 31.39049 & 26.181 & 31.01825 \\
\hline 171 & 8-Ib shot & 0.2 & 0 & 0.049204 & 30.75433 & 22.9598 & 29.72172 \\
\hline 172 & 8-Ib shot & 0.2 & 0 & 0.301166 & 31.53956 & 25.20855 & 30.84045 \\
\hline 173 & 8-Ib shot & 0.2 & 0 & 0.211244 & 32.88047 & 25.66681 & 31.96812 \\
\hline 174 & 8-Ib shot & 0.2 & 0 & 0.232691 & 32.69676 & 26.16131 & 31.94477 \\
\hline 175 & 8-Ib shot & 0.2 & 0 & 0.127781 & 31.3816 & 24.94753 & 30.6537 \\
\hline 176 & 8-Ib shot & 0.2 & 0 & 0.075472 & 30.5903 & 24.0323 & 29.83373 \\
\hline 177 & 8-Ib shot & 0.2 & 0 & 0.244884 & 32.45668 & 25.80035 & 31.67358 \\
\hline 178 & 8-Ib shot & 0.2 & 0 & 0.110277 & 32.95354 & 26.42905 & 32.20314 \\
\hline 179 & 8-Ib shot & 0.2 & 0 & 0.19598 & 31.08532 & 24.73633 & 30.37979 \\
\hline 180 & 8-Ib shot & 0.2 & 0 & 0.217789 & 31.91833 & 24.7834 & 31.02254 \\
\hline 181 & 8-Ib shot & 0.2 & 0 & 0.129449 & 31.85146 & 25.90419 & 31.25327 \\
\hline 182 & 8-Ib shot & 0.2 & 0 & 0.068264 & 32.48545 & 26.3123 & 31.82576 \\
\hline
\end{tabular}




\section{Appendix B: Activity Log}

\begin{tabular}{|c|c|c|c|c|c|c|c|c|c|c|c|c|c|c|c|c|}
\hline \multirow{2}{*}{\begin{tabular}{|l} 
Date \\
20030505
\end{tabular}} & \multirow{2}{*}{\begin{tabular}{|l}
$\begin{array}{l}\text { Start- } \\
\text { Time }\end{array}$ \\
1015
\end{tabular}} & \multirow{2}{*}{ 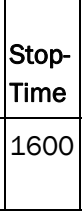 } & \multirow{2}{*}{\begin{tabular}{|l} 
Area Tested \\
CALIBRATION \\
LANES
\end{tabular}} & \multirow{2}{*}{\begin{tabular}{|l|}
$\begin{array}{l}\text { Status } \\
\text { Start } \\
\text { Time }\end{array}$ \\
1015
\end{tabular}} & \multirow{2}{*}{ 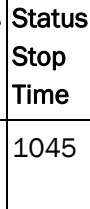 } & \multirow{2}{*}{\begin{tabular}{|l|}
$\mathrm{hr}$ \\
$0: 00$
\end{tabular}} & \multirow{2}{*}{\begin{tabular}{|l|}
$\min$ \\
30
\end{tabular}} & \multirow{2}{*}{\begin{tabular}{|l} 
Duration, \\
$\min$
\end{tabular}} & \multirow{2}{*}{\begin{tabular}{|l|} 
Op \\
Stat \\
Code
\end{tabular} \mid} & \multirow{2}{*}{ 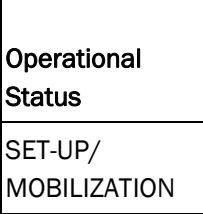 } & \multirow{2}{*}{\begin{tabular}{|l} 
Operational \\
Status-Comments
\end{tabular}} & \multirow{2}{*}{ 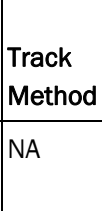 } & \multirow{2}{*}{\begin{tabular}{|l} 
Pattern \\
NA
\end{tabular}} & \multicolumn{2}{|c|}{ Field Conditions } & \multirow{2}{*}{\begin{tabular}{|l|}
$\begin{array}{l}\text { No. of } \\
\text { People }\end{array}$ \\
4
\end{tabular}} \\
\hline & & & & & & & & & & & & & & HOT & DRY & \\
\hline 20030505 & 1015 & 1600 & $\begin{array}{l}\text { CALIBRATION } \\
\text { LANES }\end{array}$ & 1015 & 1045 & $0: 00$ & 30 & 30 & 1 & $\begin{array}{l}\text { SET-UP/ } \\
\text { MOBILIZATION }\end{array}$ & $\begin{array}{l}\text { SETTING UP } \\
\text { EQUIPMENT }\end{array}$ & NA & NA & HOT & DRY & \\
\hline 20030505 & 1015 & 1600 & $\begin{array}{l}\text { CALIBRATION } \\
\text { LANES }\end{array}$ & 1045 & 1100 & 0 & 15 & 15 & 3 & BREAK/LUNCH & LUNCH & NA & NA & HOT & DRY & 4 \\
\hline 20030505 & 1015 & 1600 & $\begin{array}{l}\text { CALIBRATION } \\
\text { LANES }\end{array}$ & 1100 & 1530 & 4 & 30 & 270 & 1 & $\begin{array}{l}\text { SET-UP/ } \\
\text { MOBILIZATION }\end{array}$ & $\begin{array}{l}\text { SETTING UP } \\
\text { EQUIPMENT }\end{array}$ & NA & NA & HOT & DRY & 4 \\
\hline 20030505 & 1015 & 1600 & $\begin{array}{l}\text { CALIBRATION } \\
\text { LANES }\end{array}$ & 1530 & 1600 & 0 & 30 & 30 & 1 & $\begin{array}{l}\text { SET-UP/ } \\
\text { MOBILIZATION }\end{array}$ & $\begin{array}{l}\text { BREAKING DOWN } \\
\text { EQUIPMENT EOD }\end{array}$ & NA & NA & HOT & DRY & 4 \\
\hline 20030506 & 730 & 1535 & $\begin{array}{l}\text { CALIBRATION } \\
\text { LANES }\end{array}$ & 730 & 815 & 0 & 45 & 45 & 1 & $\begin{array}{l}\text { SET-UP/ } \\
\text { MOBILIZATION }\end{array}$ & $\begin{array}{l}\text { SETTING UP } \\
\text { EQUIPMENT }\end{array}$ & GPS & NA & HOT & DRY & 5 \\
\hline 20030506 & 730 & 1535 & $\begin{array}{l}\text { CALIBRATION } \\
\text { LANES }\end{array}$ & 815 & 915 & 1 & 0 & 60 & 2 & $\begin{array}{l}\text { COLLECTING } \\
\text { DATA }\end{array}$ & $\begin{array}{l}\text { RUNNING CAL } \\
\text { LANE, BI } \\
\text { DIRECTION, } \\
\text { NORTH/SOUTH }\end{array}$ & NA & NA & HOT & DRY & 5 \\
\hline 20030506 & 730 & 1535 & $\begin{array}{l}\text { CALIBRATION } \\
\text { LANES }\end{array}$ & 915 & 1030 & 1 & 15 & 75 & 5 & $\begin{array}{l}\text { DOWNTIME DUE } \\
\text { TO EQUIP } \\
\text { MAINT/CHECK }\end{array}$ & $\begin{array}{l}\text { CHECKING/ } \\
\text { DOWNLOADING } \\
\text { DATA }\end{array}$ & GPS & NA & HOT & DRY & 5 \\
\hline 20030506 & 730 & 1535 & $\begin{array}{l}\text { CALIBRATION } \\
\text { LANES }\end{array}$ & 1030 & 1120 & 0 & 50 & 50 & 2 & $\begin{array}{l}\text { COLLECTING } \\
\text { DATA }\end{array}$ & $\begin{array}{l}\text { RUNNING CAL } \\
\text { LANE BI } \\
\text { DIRECTION } \\
\text { EAST/WEST }\end{array}$ & GPS & NA & HOT & DRY & 5 \\
\hline 20030506 & 730 & 1535 & $\begin{array}{l}\text { CALIBRATION } \\
\text { LANES }\end{array}$ & 1120 & 1140 & 1 & 10 & 70 & 5 & $\begin{array}{l}\text { DOWNTIME DUE } \\
\text { TO EQUIP } \\
\text { MAINT/CHECK }\end{array}$ & $\begin{array}{l}\text { CHECKING/ } \\
\text { DOWNLOADING } \\
\text { DATA }\end{array}$ & NA & NA & HOT & DRY & 5 \\
\hline 20030506 & 730 & 1535 & $\begin{array}{l}\text { CALIBRATION } \\
\text { LANES }\end{array}$ & 1140 & 1210 & 0 & 30 & 30 & 3 & BREAK/LUNCH & LUNCH & GPS & NA & HOT & DRY & 5 \\
\hline 20030506 & 730 & 1535 & $\begin{array}{l}\text { CALIBRATION } \\
\text { LANES }\end{array}$ & 1210 & 1240 & 0 & 30 & 30 & 5 & $\begin{array}{l}\text { DOWNTIME DUE } \\
\text { TO EQUIP } \\
\text { MAINT/CHECK }\end{array}$ & $\begin{array}{l}\text { CHECKING/ } \\
\text { DOWNLOADING } \\
\text { DATA }\end{array}$ & NA & NA & HOT & DRY & 5 \\
\hline 20030506 & 730 & 1535 & $\begin{array}{l}\text { BLIND TEST } \\
\text { GRID }\end{array}$ & 1240 & 1355 & 1 & 15 & 75 & 2 & $\begin{array}{l}\text { COLLECTING } \\
\text { DATA }\end{array}$ & $\begin{array}{l}\text { RUNNING BTG, } \\
\text { BIDIRECTION } \\
\text { EAST/WEST }\end{array}$ & GPS & NA & НОT & DRY & 5 \\
\hline 20030506 & 730 & 1535 & $\begin{array}{l}\text { BLIND TEST } \\
\text { GRID }\end{array}$ & 1355 & 1430 & 0 & 35 & 35 & 5 & $\begin{array}{l}\text { DOWNTIME DUE } \\
\text { TO EQUIP } \\
\text { MAINT/CHECK }\end{array}$ & $\begin{array}{l}\text { CHECKING/ } \\
\text { DOWNLOADING } \\
\text { DATA }\end{array}$ & GPS & NA & HOT & DRY & 5 \\
\hline 20030506 & 730 & 1535 & $\begin{array}{l}\text { CALIBRATION } \\
\text { PIT }\end{array}$ & 1430 & 1450 & 0 & 20 & 20 & 1 & $\begin{array}{l}\text { SET-UP/ } \\
\text { MOBILIZATION }\end{array}$ & $\begin{array}{l}\text { SETTING UP } \\
\text { EQUIPMENT }\end{array}$ & GPS & NA & НОT & DRY & 5 \\
\hline 20030506 & 730 & 1535 & $\begin{array}{l}\text { CALIBRATION } \\
\text { PIT }\end{array}$ & 1450 & 1515 & 0 & 25 & 25 & 2 & $\begin{array}{l}\text { COLLECTING } \\
\text { DATA }\end{array}$ & $\begin{array}{l}\text { COLLECT DATA } \\
\text { OVER PIT }\end{array}$ & GPS & NA & HOT & DRY & 5 \\
\hline
\end{tabular}




\begin{tabular}{|c|c|c|c|c|c|c|c|c|c|c|c|c|c|c|c|c|}
\hline \multirow{2}{*}{\begin{tabular}{|l} 
Date \\
20030506
\end{tabular}} & \multirow{2}{*}{$\begin{array}{l}\text { Start- } \\
\text { Time }\end{array}$} & \multirow{2}{*}{ 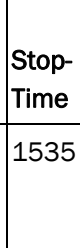 } & \multirow{2}{*}{$\begin{array}{l}\text { Area Tested } \\
\text { CALIBRATION } \\
\text { PIT }\end{array}$} & \multirow{2}{*}{\begin{tabular}{|l|}
$\begin{array}{l}\text { Status } \\
\text { Start } \\
\text { Time }\end{array}$ \\
1515 \\
\end{tabular}} & \multirow{2}{*}{\begin{tabular}{|l|}
$\begin{array}{l}\text { Status } \\
\text { Stop } \\
\text { Time }\end{array}$ \\
1520 \\
\end{tabular}} & \multirow{2}{*}{\begin{tabular}{|l} 
hr \\
0
\end{tabular}} & \multirow{2}{*}{$\begin{array}{l}\min \\
5\end{array}$} & \multirow{2}{*}{$\begin{array}{l}\text { Duration, } \\
\min \\
5\end{array}$} & \multirow{2}{*}{\begin{tabular}{|l} 
Op \\
Stat \\
Code \\
5
\end{tabular}} & \multirow{2}{*}{\begin{tabular}{|l} 
Operational \\
Status \\
DOWNTIME DUE \\
TO EQUIP \\
MAINT/CHECK \\
\end{tabular}} & \multirow{2}{*}{ 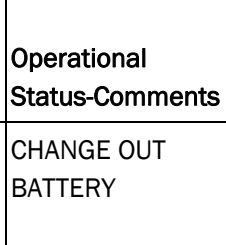 } & \multirow{2}{*}{\begin{tabular}{|l|}
$\begin{array}{l}\text { Track } \\
\text { Method }\end{array}$ \\
GPS \\
\end{tabular}} & \multirow{2}{*}{\begin{tabular}{|l|} 
Pattern \\
NA
\end{tabular}} & \multicolumn{2}{|c|}{ Field Conditions } & \multirow{2}{*}{\begin{tabular}{|l} 
No. of \\
People
\end{tabular}} \\
\hline & & & & & & & & & & & & & & HOT & DRY & \\
\hline 20030506 & 730 & 1535 & $\begin{array}{l}\text { CALIBRATION } \\
\text { PIT }\end{array}$ & 1520 & 1525 & 0 & 5 & 5 & 2 & $\begin{array}{l}\text { COLLECTING } \\
\text { DATA }\end{array}$ & $\begin{array}{l}\text { COLLECT DATA } \\
\text { OVER PIT }\end{array}$ & GPS & NA & HOT & DRY & 5 \\
\hline 20030506 & 730 & 1535 & $\begin{array}{l}\text { CALIBRATION } \\
\text { PIT }\end{array}$ & 1525 & 1535 & 0 & 10 & 10 & 1 & $\begin{array}{l}\text { SET-UP/ } \\
\text { MOBILIZATION }\end{array}$ & $\begin{array}{l}\text { BREAKING DOWN } \\
\text { EQUIPMENT EOD }\end{array}$ & NA & NA & HOT & DRY & 5 \\
\hline 20030507 & 715 & 1600 & OPEN RANGE & 715 & 855 & 1 & 40 & 100 & 1 & $\begin{array}{l}\text { SET-UP/ } \\
\text { MOBILIZATION }\end{array}$ & $\begin{array}{l}\text { SETTING UP } \\
\text { EQUIPMENT }\end{array}$ & NA & NA & COOL/WINDY & DRY & 4 \\
\hline 20030507 & 715 & 1600 & OPEN RANGE & 855 & 1035 & 1 & 40 & 100 & 2 & $\begin{array}{l}\text { COLLECTING } \\
\text { DATA }\end{array}$ & $\begin{array}{l}\text { RUNNING OPEN } \\
\text { RANGE, GRID A2, } \\
\text { BIDIRECTIONAL } \\
\text { E/W }\end{array}$ & GPS & NA & COOL/WINDY & DRY & 4 \\
\hline 20030507 & 715 & 1600 & OPEN RANGE & 1035 & 1115 & 0 & 40 & 40 & 5 & $\begin{array}{l}\text { DOWNTIME DUE } \\
\text { TO EQUIP } \\
\text { MAINT/CHECK }\end{array}$ & $\begin{array}{l}\text { CHECKING/ } \\
\text { DOWNLOADING } \\
\text { DATA }\end{array}$ & GPS & NA & HOT/WINDY & DRY & 4 \\
\hline 20030507 & 715 & 1600 & OPEN RANGE & 1115 & 1125 & 0 & 10 & 10 & 1 & $\begin{array}{l}\text { SET-UP/ } \\
\text { MOBILIZATION }\end{array}$ & $\begin{array}{l}\text { SETTING UP } \\
\text { EQUIPMENT }\end{array}$ & GPS & NA & HOT/WINDY & DRY & 4 \\
\hline 20030507 & 715 & 1600 & OPEN RANGE & 1125 & 1300 & 1 & 35 & 95 & 2 & $\begin{array}{l}\text { COLLECTING } \\
\text { DATA }\end{array}$ & $\begin{array}{l}\text { RUNNING OPEN } \\
\text { RANGE, GRID A3, } \\
\text { BIDIRECTIONAL } \\
\text { E/W }\end{array}$ & GPS & NA & HOT/WINDY & DRY & 4 \\
\hline 20030507 & 715 & 1600 & OPEN RANGE & 1300 & 1330 & 0 & 30 & 30 & 5 & $\begin{array}{l}\text { DOWNTIME DUE } \\
\text { TO EQUIP } \\
\text { MAINT/CHECK }\end{array}$ & $\begin{array}{l}\text { CHECKING/ } \\
\text { DOWNLOADING } \\
\text { DATA }\end{array}$ & GPS & NA & HOT/WINDY & DRY & 4 \\
\hline 20030507 & 715 & 1600 & OPEN RANGE & 1330 & 1350 & 0 & 20 & 20 & 3 & BREAK/LUNCH & BREAK & NA & NA & HOT/WINDY & DRY & 4 \\
\hline 20030507 & 715 & 1600 & OPEN RANGE & 1350 & 1400 & 0 & 10 & 10 & 1 & $\begin{array}{l}\text { SET-UP/ } \\
\text { MOBILIZATION }\end{array}$ & $\begin{array}{l}\text { SETTING UP } \\
\text { EQUIPMENT }\end{array}$ & NA & NA & HOT/WINDY & DRY & 4 \\
\hline 20030507 & 715 & 1600 & OPEN RANGE & 1400 & 1530 & 1 & 30 & 90 & 2 & $\begin{array}{l}\text { COLLECTING } \\
\text { DATA }\end{array}$ & $\begin{array}{l}\text { RUNNING OPEN } \\
\text { RANGE GRID G2, } \\
\text { BIDIRECTIONAL } \\
\text { E/W }\end{array}$ & GPS & NA & HOT/WINDY & DRY & 4 \\
\hline 20030507 & 715 & 1600 & OPEN RANGE & 1530 & 1550 & 0 & 20 & 20 & 5 & $\begin{array}{l}\text { DOWNTIME DUE } \\
\text { TO EQUIP } \\
\text { MAINT/CHECK }\end{array}$ & $\begin{array}{l}\text { CHECKING/ } \\
\text { DOWNLOADING } \\
\text { DATA }\end{array}$ & GPS & NA & HOT/WINDY & DRY & 4 \\
\hline 20030507 & 715 & 1600 & OPEN RANGE & 1550 & 1600 & 0 & 10 & 10 & 1 & $\begin{array}{l}\text { SET-UP/ } \\
\text { MOBILIZATION }\end{array}$ & $\begin{array}{l}\text { BREAKING DOWN } \\
\text { EQUIPMENT EOD }\end{array}$ & NA & NA & HOT/WINDY & DRY & 4 \\
\hline 20030508 & 700 & 1600 & OPEN RANGE & 700 & 745 & 0 & 45 & 45 & 1 & $\begin{array}{l}\text { SET-UP/ } \\
\text { MOBILIZATION }\end{array}$ & $\begin{array}{l}\text { SETTING UP } \\
\text { EQUIPMENT }\end{array}$ & NA & NA & COOL/WINDY & DRY & 5 \\
\hline 20030508 & 700 & 1600 & OPEN RANGE & 745 & 950 & 2 & 5 & 125 & 2 & $\begin{array}{l}\text { COLLECTING } \\
\text { DATA }\end{array}$ & $\begin{array}{l}\text { RUNNING OPEN } \\
\text { RANGE, GRID } \\
\text { G3,G4, } \\
\text { BIDIRECTIONAL } \\
\text { E/W }\end{array}$ & GPS & NA & COOL/WINDY & DRY & 5 \\
\hline 20030508 & 700 & 1600 & OPEN RANGE & 950 & 1020 & 0 & 30 & 30 & 5 & $\begin{array}{l}\text { DOWNTIME DUE } \\
\text { TO EQUIP } \\
\text { MAINT/CHECK }\end{array}$ & $\begin{array}{l}\text { CHECKING/ } \\
\text { DOWNLOADING } \\
\text { DATA }\end{array}$ & GPS & NA & COOL/WINDY & DRY & 5 \\
\hline
\end{tabular}




\begin{tabular}{|c|c|c|c|c|c|c|c|c|c|c|c|c|c|c|c|c|}
\hline Date & $\begin{array}{l}\text { Start- } \\
\text { Time }\end{array}$ & $\begin{array}{l}\text { Stop- } \\
\text { Time }\end{array}$ & Area Tested & $\begin{array}{l}\text { Status } \\
\text { Start } \\
\text { Time }\end{array}$ & $\begin{array}{l}\text { Status } \\
\text { Stop } \\
\text { Time }\end{array}$ & hr & $\min$ & $\begin{array}{l}\text { Duration, } \\
\min \end{array}$ & $\begin{array}{l}\text { Op } \\
\text { Stat } \\
\text { Code }\end{array}$ & $\begin{array}{l}\text { Operational } \\
\text { Status }\end{array}$ & $\begin{array}{l}\text { Operational } \\
\text { Status-Comments }\end{array}$ & $\begin{array}{l}\text { Track } \\
\text { Method }\end{array}$ & Pattern & \multicolumn{2}{|c|}{ Field Conditions } & $\begin{array}{l}\text { No. of } \\
\text { People }\end{array}$ \\
\hline 20030508 & 700 & 1600 & $\begin{array}{l}\text { BLIND TEST } \\
\text { GRID }\end{array}$ & 1020 & 1130 & 1 & 10 & 70 & 2 & $\begin{array}{l}\text { COLLECTING } \\
\text { DATA }\end{array}$ & $\begin{array}{l}\text { RUNNING BTG } \\
\text { BIDIRECTIONAL } \\
\text { NORTH/ SOUTH }\end{array}$ & GPS & NA & HOT/WINDY & DRY & 5 \\
\hline 20030508 & 700 & 1600 & $\begin{array}{l}\text { BLIND TEST } \\
\text { GRID }\end{array}$ & 1130 & 1145 & 0 & 15 & 15 & 5 & $\begin{array}{l}\text { DOWNTIME DUE } \\
\text { TO EQUIP } \\
\text { MAINT/CHECK }\end{array}$ & $\begin{array}{l}\text { CHECKING/ } \\
\text { DOWNLOADING } \\
\text { DATA }\end{array}$ & GPS & NA & HOT/WINDY & DRY & 5 \\
\hline 20030508 & 700 & 1600 & $\begin{array}{l}\text { BLIND TEST } \\
\text { GRID }\end{array}$ & 1145 & 1215 & 0 & 30 & 30 & 3 & BREAK/LUNCH & LUNCH & GPS & NA & HOT/WINDY & DRY & 5 \\
\hline 20030508 & 700 & 1600 & OPEN RANGE & 1215 & 1300 & 0 & 45 & 45 & 1 & $\begin{array}{l}\text { SET-UP/ } \\
\text { MOBILIZATION }\end{array}$ & $\begin{array}{l}\text { LAYOUT LANES } \\
\text { WITH ROPE }\end{array}$ & NA & NA & HOT/WINDY & DRY & 5 \\
\hline 20030508 & 700 & 1600 & $\begin{array}{l}\text { CALIBRATION } \\
\text { PIT }\end{array}$ & 1300 & 1440 & 1 & 40 & 100 & 2 & $\begin{array}{l}\text { COLLECTING } \\
\text { DATA }\end{array}$ & $\begin{array}{l}\text { COLLECT DATA } \\
\text { OVER PIT }\end{array}$ & GPS & NA & HOT/WINDY & DRY & 5 \\
\hline 20030508 & 700 & 1600 & $\begin{array}{l}\text { CALIBRATION } \\
\text { PIT }\end{array}$ & 1440 & 1500 & 0 & 20 & 20 & 3 & BREAK/LUNCH & BREAK & NA & NA & HOT/WINDY & DRY & 5 \\
\hline 20030508 & 700 & 1600 & OPEN RANGE & 1500 & 1550 & 0 & 50 & 50 & 1 & $\begin{array}{l}\text { SET-UP/ } \\
\text { MOBILIZATION }\end{array}$ & $\begin{array}{l}\text { LAYOUT LANES } \\
\text { WITH ROPE }\end{array}$ & NA & NA & HOT/WINDY & DRY & 5 \\
\hline 20030508 & 700 & 1600 & OPEN RANGE & 1550 & 1600 & 0 & 10 & 10 & 1 & $\begin{array}{l}\text { SET-UP/ } \\
\text { MOBILIZATION }\end{array}$ & $\begin{array}{l}\text { BREAKING DOWN } \\
\text { EQUIPMENT EOD }\end{array}$ & NA & NA & HOT/WINDY & DRY & 5 \\
\hline 20030509 & 645 & 1545 & OPEN RANGE & 645 & 720 & 0 & 35 & 35 & 1 & $\begin{array}{l}\text { SET-UP/ } \\
\text { MOBILIZATION }\end{array}$ & $\begin{array}{l}\text { SETTING UP } \\
\text { EQUIPMENT }\end{array}$ & NA & NA & COOL & DRY & 4 \\
\hline 20030509 & 645 & 1545 & OPEN RANGE & 720 & 845 & 1 & 25 & 85 & 2 & $\begin{array}{l}\text { COLLECTING } \\
\text { DATA }\end{array}$ & $\begin{array}{l}\text { RUNNING OPEN } \\
\text { RANGE, GRID } \\
\text { F2,F3,F4,F5 } \\
\text { BIDIRECTIONAL } \\
\text { E/W }\end{array}$ & GPS & LINEAR & COOL/WINDY & DRY & 4 \\
\hline 20030509 & 645 & 1545 & OPEN RANGE & 845 & 905 & 0 & 20 & 20 & 5 & $\begin{array}{l}\text { DOWNTIME DUE } \\
\text { TO EQUIP } \\
\text { MAINT/CHECK }\end{array}$ & $\begin{array}{l}\text { CHECKING/ } \\
\text { DOWNLOADING } \\
\text { DATA }\end{array}$ & GPS & NA & COOL/WINDY & DRY & 4 \\
\hline 20030509 & 645 & 1545 & OPEN RANGE & 905 & 1030 & 1 & 25 & 85 & 2 & $\begin{array}{l}\text { COLLECTING } \\
\text { DATA }\end{array}$ & $\begin{array}{l}\text { RUNNING OPEN } \\
\text { RANGE, GRID } \\
\text { F2,F3,F4,F5 } \\
\text { BIDIRECTIONAL } \\
\text { E/W }\end{array}$ & GPS & LINEAR & COOL/WINDY & DRY & 4 \\
\hline 20030509 & 645 & 1545 & OPEN RANGE & 1030 & 1100 & 0 & 30 & 30 & 5 & $\begin{array}{l}\text { DOWNTIME DUE } \\
\text { TO EQUIP } \\
\text { MAINT/CHECK }\end{array}$ & $\begin{array}{l}\text { CHECKING/ } \\
\text { DOWNLOADING } \\
\text { DATA }\end{array}$ & GPS & NA & COOL/WINDY & DRY & 4 \\
\hline 20030509 & 645 & 1545 & OPEN RANGE & 1100 & 1130 & 0 & 30 & 30 & 3 & BREAK/LUNCH & LUNCH & NA & NA & COOL/WINDY & DRY & 4 \\
\hline 20030509 & 645 & 1545 & OPEN RANGE & 1130 & 1250 & 1 & 20 & 80 & 2 & $\begin{array}{l}\text { COLLECTING } \\
\text { DATA }\end{array}$ & $\begin{array}{l}\text { RUNNING OPEN } \\
\text { RANGE, GRID } \\
\text { F2,F3,F4,F5 } \\
\text { BIDIRECTIONAL } \\
\text { E/W }\end{array}$ & GPS & LINEAR & HOT/WINDY & DRY & 4 \\
\hline 20030509 & 645 & 1545 & OPEN RANGE & 1250 & 1300 & 0 & 10 & 10 & 5 & $\begin{array}{l}\text { DOWNTIME DUE } \\
\text { TO EQUIP } \\
\text { MAINT/CHECK }\end{array}$ & \begin{tabular}{|l} 
CHANGE OUT \\
PROCESSOR UNIT
\end{tabular} & GPS & NA & HOT/WINDY & DRY & 4 \\
\hline
\end{tabular}




\begin{tabular}{|c|c|c|c|c|c|c|c|c|c|c|c|c|c|c|c|c|}
\hline Date & $\begin{array}{l}\text { Start- } \\
\text { Time }\end{array}$ & $\begin{array}{l}\text { Stop- } \\
\text { Time }\end{array}$ & Area Tested & $\begin{array}{l}\text { Status } \\
\text { Start } \\
\text { Time }\end{array}$ & $\begin{array}{l}\text { Status } \\
\text { Stop } \\
\text { Time }\end{array}$ & hr & $\min$ & $\begin{array}{l}\text { Duration, } \\
\min \end{array}$ & $\begin{array}{l}\text { Op } \\
\text { Stat } \\
\text { Code }\end{array}$ & $\begin{array}{l}\text { Operational } \\
\text { Status }\end{array}$ & $\begin{array}{l}\text { Operational } \\
\text { Status-Comments }\end{array}$ & $\begin{array}{l}\text { Track } \\
\text { Method }\end{array}$ & Pattern & \multicolumn{2}{|c|}{ Field Conditions } & $\begin{array}{l}\text { No. of } \\
\text { People }\end{array}$ \\
\hline 20030509 & 645 & 1545 & OPEN RANGE & 1300 & 1330 & 0 & 30 & 30 & 2 & $\begin{array}{l}\text { COLLECTING } \\
\text { DATA }\end{array}$ & $\begin{array}{l}\text { RUNNING OPEN } \\
\text { RANGE, GRID } \\
\text { F2,F3,F4,F5 } \\
\text { BIDIRECTIONAL } \\
\text { E/W }\end{array}$ & GPS & LINEAR & HOT/WINDY & DRY & 5 \\
\hline 20030509 & 645 & 1545 & OPEN RANGE & 1330 & 1430 & 1 & 0 & 60 & 5 & $\begin{array}{l}\text { DOWNTIME DUE } \\
\text { TO EQUIP } \\
\text { MAINT/CHECK }\end{array}$ & $\begin{array}{l}\text { CHECKING/ } \\
\text { DOWNLOADING } \\
\text { DATA }\end{array}$ & GPS & NA & HOT/WINDY & DRY & 5 \\
\hline 20030509 & 645 & 1545 & OPEN RANGE & 1430 & 1445 & 0 & 15 & 15 & 2 & $\begin{array}{l}\text { COLLECTING } \\
\text { DATA }\end{array}$ & $\begin{array}{l}\text { RUNNING OPEN } \\
\text { RANGE, GRID } \\
\text { F2,F3,F4,F5 } \\
\text { BIDIRECTIONAL } \\
\text { E/W }\end{array}$ & GPS & LINEAR & HOT/WINDY & DRY & 5 \\
\hline 20030509 & 645 & 1545 & OPEN RANGE & 1445 & 1500 & 0 & 15 & 15 & 5 & $\begin{array}{l}\text { DOWNTIME DUE } \\
\text { TO EQUIP } \\
\text { MAINT/CHECK }\end{array}$ & $\begin{array}{l}\text { CHANGE OUT } \\
\text { BATTERY }\end{array}$ & GPS & NA & HOT/WINDY & DRY & 5 \\
\hline 20030509 & 645 & 1545 & OPEN RANGE & 1500 & 1520 & 0 & 20 & 20 & 2 & $\begin{array}{l}\text { COLLECTING } \\
\text { DATA }\end{array}$ & $\begin{array}{l}\text { RUNNING OPEN } \\
\text { RANGE, GRID } \\
\text { F2,F3,F4,F5 } \\
\text { BIDIRECTIONAL } \\
\text { E/W }\end{array}$ & GPS & LINEAR & HOT/WINDY & DRY & 5 \\
\hline 20030509 & 645 & 1545 & OPEN RANGE & 1520 & 1540 & 0 & 20 & 20 & 1 & $\begin{array}{l}\text { SET-UP/ } \\
\text { MOBILIZATION }\end{array}$ & $\begin{array}{l}\text { BREAKING DOWN } \\
\text { EQUIPMENT EOD }\end{array}$ & NA & NA & HOT/WINDY & DRY & 5 \\
\hline 20030510 & 630 & 1400 & OPEN RANGE & 630 & 700 & 0 & 30 & 30 & 1 & $\begin{array}{l}\text { SET-UP/ } \\
\text { MOBILIZATION }\end{array}$ & $\begin{array}{l}\text { SETTING UP } \\
\text { EQUIPMENT }\end{array}$ & NA & NA & COOL & DRY & 5 \\
\hline 20030510 & 630 & 1400 & OPEN RANGE & 700 & 826 & 1 & 26 & 86 & 2 & $\begin{array}{l}\text { COLLECTING } \\
\text { DATA }\end{array}$ & $\begin{array}{l}\text { RUNNING OPEN } \\
\text { RANGE, GRID } \\
\text { E2,E3,E4,E5 } \\
\text { BIDIRECTIONAL } \\
\text { E/W }\end{array}$ & GPS & LINEAR & $\mathrm{COOL}$ & DRY & 5 \\
\hline 20030510 & 630 & 1400 & OPEN RANGE & 826 & 828 & 0 & 2 & 2 & 5 & $\begin{array}{l}\text { DOWNTIME DUE } \\
\text { TO EQUIP } \\
\text { MAINT/CHECK }\end{array}$ & $\begin{array}{l}\text { SWAPPED OUT } \\
\text { FIELD COMPUTER }\end{array}$ & GPS & LINEAR & $\mathrm{COOL}$ & DRY & 5 \\
\hline 20030510 & 630 & 1400 & OPEN RANGE & 828 & 1015 & 1 & 47 & 107 & 2 & $\begin{array}{l}\text { COLLECTING } \\
\text { DATA }\end{array}$ & $\begin{array}{l}\text { RUNNING OPEN } \\
\text { RANGE, GRID } \\
\text { E2,E3,E4,E5 } \\
\text { BIDIRECTIONAL } \\
\text { E/W }\end{array}$ & GPS & LINEAR & HOT & DRY & 5 \\
\hline 20030510 & 630 & 1400 & OPEN RANGE & 1015 & 1040 & 0 & 25 & 25 & 3 & BREAK/LUNCH & LUNCH & NA & NA & HOT & DRY & 5 \\
\hline 20030510 & 630 & 1400 & OPEN RANGE & 1040 & 1100 & 0 & 20 & 20 & 5 & $\begin{array}{l}\text { DOWNTIME DUE } \\
\text { TO EQUIP } \\
\text { MAINT/CHECK }\end{array}$ & $\begin{array}{l}\text { CHECKING/ } \\
\text { DOWNLOADING } \\
\text { DATA }\end{array}$ & GPS & NA & HOT & DRY & 5 \\
\hline 20030510 & 630 & 1400 & OPEN RANGE & 1100 & 1243 & 1 & 43 & 103 & 2 & $\begin{array}{l}\text { COLLECTING } \\
\text { DATA }\end{array}$ & $\begin{array}{l}\text { RUNNING } \\
\text { OPENRANGE, GRID } \\
\text { E2,E3,E4,E5 } \\
\text { BIDIRECTIONAL } \\
\text { E/W }\end{array}$ & GPS & LINEAR & HOT & DRY & 4 \\
\hline 20030510 & 630 & 1400 & OPEN RANGE & 1243 & 1246 & 0 & 3 & 3 & 5 & $\begin{array}{l}\text { DOWNTIME DUE } \\
\text { TO EQUIP } \\
\text { MAINT/CHECK }\end{array}$ & $\begin{array}{l}\text { CHANGE OUT } \\
\text { PROCESSOR UNIT }\end{array}$ & GPS & NA & HOT & DRY & 4 \\
\hline
\end{tabular}




\begin{tabular}{|c|c|c|c|c|c|c|c|c|c|c|c|c|c|c|c|c|}
\hline \multirow{2}{*}{\begin{tabular}{|l} 
Date \\
20030510
\end{tabular}} & \multirow{2}{*}{\begin{tabular}{|l|}
$\begin{array}{l}\text { Start- } \\
\text { Time }\end{array}$ \\
630 \\
\end{tabular}} & \multirow{2}{*}{\begin{tabular}{|l|}
$\begin{array}{l}\text { Stop- } \\
\text { Time }\end{array}$ \\
1400 \\
\end{tabular}} & \multirow{2}{*}{$\begin{array}{l}\text { Area Tested } \\
\text { OPEN RANGE }\end{array}$} & \multirow{2}{*}{\begin{tabular}{|l|}
$\begin{array}{l}\text { Status } \\
\text { Start } \\
\text { Time }\end{array}$ \\
1246 \\
\end{tabular}} & \multirow{2}{*}{\begin{tabular}{|l|}
$\begin{array}{l}\text { Status } \\
\text { Stop } \\
\text { Time }\end{array}$ \\
1340
\end{tabular}} & \multirow{2}{*}{$\begin{array}{l}\mathrm{hr} \\
\mathrm{O}\end{array}$} & \multirow{2}{*}{\begin{tabular}{|l|}
$\min$ \\
54
\end{tabular}} & \multirow{2}{*}{$\begin{array}{l}\text { Duration, } \\
\min \end{array}$} & \multirow{2}{*}{\begin{tabular}{|l|} 
Op \\
Stat \\
Code \\
2 \\
\end{tabular}} & \multirow{2}{*}{\begin{tabular}{|l} 
Operational \\
Status
\end{tabular}} & \multirow{2}{*}{\begin{tabular}{|l} 
Operational \\
Status-Comments \\
RUNNING OPEN \\
RANGE, GRID \\
E2,E3,E4,E5 \\
BIDIRECTIONAL \\
E/W
\end{tabular}} & \multirow{2}{*}{\begin{tabular}{|l|} 
Track \\
Method
\end{tabular}} & \multirow{2}{*}{\begin{tabular}{|l|} 
Pattern \\
LINEAR
\end{tabular}} & \multicolumn{2}{|c|}{ Field Conditions } & \multirow{2}{*}{\begin{tabular}{|l|} 
No. of \\
People
\end{tabular}} \\
\hline & & & & & & & & & & & & & & HOT & DRY & \\
\hline 20030510 & 630 & 1400 & OPEN RANGE & 1340 & 1400 & 0 & 20 & 20 & 1 & $\begin{array}{l}\text { SET-UP/ } \\
\text { MOBILIZATION }\end{array}$ & $\begin{array}{l}\text { BREAKING DOWN } \\
\text { EQUIPMENT EOD }\end{array}$ & GPS & NA & HOT & DRY & 4 \\
\hline 20030512 & 700 & 1330 & OPEN RANGE & 700 & 721 & 0 & 21 & 21 & 1 & $\begin{array}{l}\text { SET-UP/ } \\
\text { MOBILIZATION }\end{array}$ & $\begin{array}{l}\text { SETTING UP } \\
\text { EQUIPMENT }\end{array}$ & GPS & NA & HOT & DRY & 5 \\
\hline 20030512 & 700 & 1330 & OPEN RANGE & 721 & 725 & 0 & 4 & 4 & 2 & $\begin{array}{l}\text { COLLECTING } \\
\text { DATA }\end{array}$ & $\begin{array}{l}\text { EQUIPMENT WAS } \\
\text { CALIBRATED } \\
\text { USING CAL BALL }\end{array}$ & GPS & NA & HOT & DRY & 5 \\
\hline 20030512 & 700 & 1330 & OPEN RANGE & 725 & 825 & 1 & 0 & 60 & 2 & $\begin{array}{l}\text { COLLECTING } \\
\text { DATA }\end{array}$ & $\begin{array}{l}\text { RUNNING OPEN } \\
\text { RANGE, GRID } \\
\text { E2,E3,E4,E5 } \\
\text { BIDIRECTIONAL } \\
\text { E/W }\end{array}$ & GPS & LINEAR & HOT & DRY & 5 \\
\hline 20030512 & 700 & 1330 & OPEN RANGE & 825 & 935 & 0 & 50 & 50 & 5 & $\begin{array}{l}\text { DOWNTIME DUE } \\
\text { TO EQUIP } \\
\text { MAINT/CHECK }\end{array}$ & $\begin{array}{l}\text { CHECKING/ } \\
\text { DOWNLOADING } \\
\text { DATA }\end{array}$ & GPS & NA & HOT & DRY & 5 \\
\hline 20030512 & 700 & 1330 & OPEN RANGE & 935 & 1025 & 0 & 50 & 50 & 2 & $\begin{array}{l}\text { COLLECTING } \\
\text { DATA }\end{array}$ & $\begin{array}{l}\text { RUNNING OPEN } \\
\text { RANGE, GRID } \\
\text { A4,A5 } \\
\text { BIDIRECTIONAL } \\
\text { E/W }\end{array}$ & GPS & LINEAR & HOT & DRY & 5 \\
\hline 20030512 & 700 & 1330 & OPEN RANGE & 1025 & 1030 & 0 & 5 & 5 & 5 & $\begin{array}{l}\text { DOWNTIME DUE } \\
\text { TO EQUIP } \\
\text { MAINT/CHECK }\end{array}$ & $\begin{array}{l}\text { CHECKING/ } \\
\text { DOWNLOADING } \\
\text { DATA }\end{array}$ & GPS & NA & HOT & DRY & 5 \\
\hline 20030512 & 700 & 1330 & OPEN RANGE & 1030 & 1325 & 2 & 55 & 175 & 4 & $\begin{array}{l}\text { DOWNTIME DUE } \\
\text { TO EQUIP } \\
\text { FAILURE }\end{array}$ & $\begin{array}{l}\text { WHEEL AXLE } \\
\text { BROKE }\end{array}$ & NA & NA & HOT & DRY & 5 \\
\hline 20030512 & 700 & 1330 & OPEN RANGE & 1325 & 1330 & 0 & 5 & 5 & 1 & $\begin{array}{l}\text { SET-UP/ } \\
\text { MOBILIZATION }\end{array}$ & $\begin{array}{l}\text { BREAKING DOWN } \\
\text { EQUIPMENT EOD }\end{array}$ & NA & NA & HOT & DRY & 5 \\
\hline 20030513 & 1130 & 1600 & OPEN RANGE & 1130 & 1215 & 0 & 45 & 45 & 1 & $\begin{array}{l}\text { SET-UP/ } \\
\text { MOBILIZATION }\end{array}$ & $\begin{array}{l}\text { SETTING UP } \\
\text { EQUIPMENT }\end{array}$ & GPS & NA & HOT & DRY & 4 \\
\hline 20030513 & 1130 & 1600 & OPEN RANGE & 1215 & 1300 & 0 & 45 & 45 & 2 & $\begin{array}{l}\text { COLLECTING } \\
\text { DATA }\end{array}$ & $\begin{array}{l}\text { RUNNING OPEN } \\
\text { RANGE, A4,A5 } \\
\text { BIDIRECTIONAL } \\
\text { E/W }\end{array}$ & GPS & LINEAR & HOT & DRY & 4 \\
\hline 20030513 & 1130 & 1600 & OPEN RANGE & 1300 & 1320 & 0 & 20 & 20 & 5 & $\begin{array}{l}\text { DOWNTIME DUE } \\
\text { TO EQUIP } \\
\text { MAINT/CHECK }\end{array}$ & $\begin{array}{l}\text { CHECKING/ } \\
\text { DOWNLOADING } \\
\text { DATA }\end{array}$ & GPS & NA & HOT & DRY & 4 \\
\hline 20030513 & 1130 & 1600 & OPEN RANGE & 1320 & 1430 & 1 & 10 & 70 & 2 & $\begin{array}{l}\text { COLLECTING } \\
\text { DATA }\end{array}$ & $\begin{array}{l}\text { RUNNING OPEN } \\
\text { RANGE, A4,A5 } \\
\text { BIDIRECTIONAL } \\
\text { E/W }\end{array}$ & GPS & LINEAR & HOT & DRY & 4 \\
\hline 20030513 & 1130 & 1600 & OPEN RANGE & 1430 & 1447 & 0 & 17 & 17 & 3 & BREAK/LUNCH & BREAK & NA & NA & HOT & DRY & 4 \\
\hline
\end{tabular}




\begin{tabular}{|c|c|c|c|c|c|c|c|c|c|c|c|c|c|c|c|c|}
\hline Date & $\begin{array}{l}\text { Start- } \\
\text { Time }\end{array}$ & $\begin{array}{l}\text { Stop- } \\
\text { Time }\end{array}$ & Area Tested & $\begin{array}{l}\text { Status } \\
\text { Start } \\
\text { Time }\end{array}$ & $\begin{array}{l}\text { Status } \\
\text { Stop } \\
\text { Time }\end{array}$ & hr & $\min$ & $\begin{array}{l}\text { Duration, } \\
\min \end{array}$ & $\begin{array}{l}\text { Op } \\
\text { Stat } \\
\text { Code }\end{array}$ & $\begin{array}{l}\text { Operational } \\
\text { Status }\end{array}$ & $\begin{array}{l}\text { Operational } \\
\text { Status-Comments }\end{array}$ & $\begin{array}{l}\text { Track } \\
\text { Method }\end{array}$ & Pattern & \multicolumn{2}{|c|}{ Field Conditions } & $\begin{array}{l}\text { No. of } \\
\text { People }\end{array}$ \\
\hline 20030513 & 1130 & 1600 & OPEN RANGE & 1447 & 1535 & 0 & 48 & 48 & 2 & $\begin{array}{l}\text { COLLECTING } \\
\text { DATA }\end{array}$ & $\begin{array}{l}\text { RUNNING OPEN } \\
\text { RANGE, A4,A5 } \\
\text { BIDIRECTIONAL } \\
\text { E/W }\end{array}$ & NA & LINEAR & HOT & DRY & 4 \\
\hline 20030513 & 1130 & 1600 & OPEN RANGE & 1535 & 1545 & 0 & 10 & 10 & 5 & $\begin{array}{l}\text { DOWNTIME DUE } \\
\text { TO EQUIP } \\
\text { MAINT/CHECK }\end{array}$ & $\begin{array}{l}\text { CHECKING/ } \\
\text { DOWNLOADING } \\
\text { DATA }\end{array}$ & GPS & NA & HOT & DRY & 4 \\
\hline 20030513 & 1130 & 1600 & OPEN RANGE & 1545 & 1600 & 0 & 15 & 15 & 1 & $\begin{array}{l}\text { SET-UP/ } \\
\text { MOBILIZATION }\end{array}$ & $\begin{array}{l}\text { BREAKING DOWN } \\
\text { EQUIPMENT EOD }\end{array}$ & NA & NA & HOT & DRY & 4 \\
\hline 20030514 & 630 & 1600 & OPEN RANGE & 630 & 735 & 1 & 5 & 65 & 1 & $\begin{array}{l}\text { SET-UP/ } \\
\text { MOBILIZATION }\end{array}$ & $\begin{array}{l}\text { SETTING UP } \\
\text { EQUIPMENT }\end{array}$ & NA & NA & WARM & HUMID & 5 \\
\hline 20030514 & 630 & 1600 & OPEN RANGE & 735 & 739 & 0 & 4 & 4 & 2 & $\begin{array}{l}\text { COLLECTING } \\
\text { DATA }\end{array}$ & $\begin{array}{l}\text { EQUIPMENT WAS } \\
\text { CALIBRATED } \\
\text { USING CAL BALL }\end{array}$ & GPS & LINEAR & WARM & HUMID & 5 \\
\hline 20030514 & 630 & 1600 & OPEN RANGE & 739 & 850 & 1 & 11 & 71 & 2 & $\begin{array}{l}\text { COLLECTING } \\
\text { DATA }\end{array}$ & $\begin{array}{l}\text { RUNNING OPEN } \\
\text { RANGE, A4,A5 } \\
\text { BIDIRECTIONAL } \\
\text { E/W }\end{array}$ & GPS & LINEAR & WARM & HUMID & 5 \\
\hline 20030514 & 630 & 1600 & OPEN RANGE & 850 & 920 & 0 & 30 & 30 & 5 & $\begin{array}{l}\text { DOWNTIME DUE } \\
\text { TO EQUIP } \\
\text { MAINT/CHECK }\end{array}$ & $\begin{array}{l}\text { CHECKING/ } \\
\text { DOWNLOADING } \\
\text { DATA }\end{array}$ & GPS & NA & WARM & HUMID & 5 \\
\hline 20030514 & 630 & 1600 & OPEN RANGE & 920 & 1020 & 1 & 0 & 60 & 2 & $\begin{array}{l}\text { COLLECTING } \\
\text { DATA }\end{array}$ & $\begin{array}{l}\text { RUNNING OPEN } \\
\text { RANGE, D4,D5 } \\
\text { BIDIRECTIONAL } \\
\text { E/W }\end{array}$ & GPS & LINEAR & WARM & HUMID & 5 \\
\hline 20030514 & 630 & 1600 & OPEN RANGE & 1020 & 1035 & 0 & 15 & 15 & 5 & $\begin{array}{l}\text { DOWNTIME DUE } \\
\text { TO EQUIP } \\
\text { MAINT/CHECK }\end{array}$ & $\begin{array}{l}\text { CHECKING/ } \\
\text { DOWNLOADING } \\
\text { DATA }\end{array}$ & GPS & NA & WARM & HUMID & 5 \\
\hline 20030514 & 630 & 1600 & OPEN RANGE & 1035 & 1130 & 0 & 55 & 55 & 3 & BREAK/LUNCH & LUNCH & NA & NA & WARM & HUMID & 5 \\
\hline 20030514 & 630 & 1600 & OPEN RANGE & 1130 & 1325 & 1 & 55 & 115 & 2 & $\begin{array}{l}\text { COLLECTING } \\
\text { DATA }\end{array}$ & $\begin{array}{l}\text { RUNNING OPEN } \\
\text { RANGE, D4,D5 } \\
\text { BIDIRECTIONAL } \\
\text { E/W }\end{array}$ & GPS & LINEAR & WARM & HUMID & 5 \\
\hline 20030514 & 630 & 1600 & OPEN RANGE & 1325 & 1400 & 0 & 35 & 35 & 5 & $\begin{array}{l}\text { DOWNTIME DUE } \\
\text { TO EQUIP } \\
\text { MAINT/CHECK }\end{array}$ & $\begin{array}{l}\text { CHECKING/ } \\
\text { DOWNLOADING } \\
\text { DATA }\end{array}$ & GPS & NA & WARM & HUMID & 5 \\
\hline 20030514 & 630 & 1600 & OPEN RANGE & 1400 & 1430 & 0 & 30 & 30 & 3 & BREAK/LUNCH & BREAK & NA & NA & WARM & HUMID & 5 \\
\hline 20030514 & 630 & 1600 & OPEN RANGE & 1430 & 1530 & 2 & 0 & 120 & 2 & $\begin{array}{l}\text { COLLECTING } \\
\text { DATA }\end{array}$ & $\begin{array}{l}\text { RUNNING OPEN } \\
\text { RANGE, D4,D5 } \\
\text { BIDIRECTIONAL } \\
\text { E/W }\end{array}$ & GPS & LINEAR & WARM & HUMID & 5 \\
\hline 20030514 & 630 & 1600 & OPEN RANGE & 1530 & 1600 & 0 & 30 & 30 & 1 & $\begin{array}{l}\text { SET-UP/ } \\
\text { MOBILIZATION }\end{array}$ & $\begin{array}{l}\text { BREAKING DOWN } \\
\text { EQUIPMENT EOD }\end{array}$ & NA & NA & WARM & HUMID & 5 \\
\hline 20030515 & 645 & 1600 & OPEN RANGE & 645 & 710 & 0 & 25 & 25 & 1 & $\begin{array}{l}\text { SET-UP/ } \\
\text { MOBILIZATION }\end{array}$ & $\begin{array}{l}\text { SETTING UP } \\
\text { EQUIPMENT }\end{array}$ & NA & NA & $\mathrm{COOL}$ & DRY & 5 \\
\hline
\end{tabular}




\begin{tabular}{|c|c|c|c|c|c|c|c|c|c|c|c|c|c|c|c|c|}
\hline \multirow{2}{*}{\begin{tabular}{|l} 
Date \\
20030515
\end{tabular}} & \multirow{2}{*}{\begin{tabular}{|l} 
Start \\
Time \\
645
\end{tabular}} & \multirow{2}{*}{\begin{tabular}{|l|}
$\begin{array}{l}\text { Stop- } \\
\text { Time }\end{array}$ \\
1600
\end{tabular}} & \multirow{2}{*}{$\begin{array}{l}\text { Area Tested } \\
\text { OPEN RANGE }\end{array}$} & \multirow{2}{*}{ 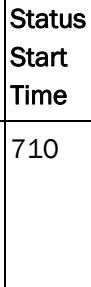 } & \multirow{2}{*}{\begin{tabular}{|l|}
$\begin{array}{l}\text { Status } \\
\text { Stop } \\
\text { Time }\end{array}$ \\
735 \\
\end{tabular}} & \multirow{2}{*}{$\begin{array}{l}\text { hr } \\
0\end{array}$} & \multirow{2}{*}{$\begin{array}{l}\min \\
25\end{array}$} & \multirow{2}{*}{\begin{tabular}{|l} 
Duration, \\
min \\
25
\end{tabular}} & \multirow{2}{*}{\begin{tabular}{|l} 
Op \\
Stat \\
Code \\
2
\end{tabular}} & \multirow{2}{*}{\begin{tabular}{|l} 
Operational \\
Status
\end{tabular}} & \multirow{2}{*}{$\begin{array}{l}\text { Operational } \\
\text { Status-Comments } \\
\text { RUNNING OPEN } \\
\text { RANGE, B2,B3 } \\
\text { BIDIRECTIONAL } \\
\text { E/W }\end{array}$} & \multirow{2}{*}{\begin{tabular}{|l|}
$\begin{array}{l}\text { Track } \\
\text { Method }\end{array}$ \\
GPS \\
\end{tabular}} & \multirow{2}{*}{\begin{tabular}{|l|} 
Pattern \\
LINEAR
\end{tabular}} & \multicolumn{2}{|c|}{ Field Conditions } & \multirow{2}{*}{\begin{tabular}{|l} 
No. of \\
People \\
5
\end{tabular}} \\
\hline & & & & & & & & & & & & & & COOL & DRY & \\
\hline 20030515 & 645 & 1600 & OPEN RANGE & 735 & 742 & 0 & 7 & 7 & 5 & $\begin{array}{l}\text { DOWNTIME DUE } \\
\text { TO EQUIP } \\
\text { MAINT/CHECK }\end{array}$ & $\begin{array}{l}\text { CHECKING/ } \\
\text { DOWNLOADING } \\
\text { DATA }\end{array}$ & GPS & NA & COOL & DRY & 5 \\
\hline 20030515 & 645 & 1600 & OPEN RANGE & 742 & 750 & 0 & 8 & 8 & 2 & $\begin{array}{l}\text { COLLECTING } \\
\text { DATA }\end{array}$ & $\begin{array}{l}\text { RUNNING OPEN } \\
\text { RANGE, B2,B3 } \\
\text { BIDIRECTIONAL } \\
\text { E/W }\end{array}$ & GPS & LINEAR & $\mathrm{COOL}$ & DRY & 5 \\
\hline 20030515 & 645 & 1600 & OPEN RANGE & 750 & 755 & 0 & 5 & 5 & 4 & $\begin{array}{l}\text { DOWNTIME DUE } \\
\text { TO EQUIP } \\
\text { FAILURE }\end{array}$ & GPS DOWN & GPS & NA & $\mathrm{COOL}$ & DRY & 5 \\
\hline 20030515 & 645 & 1600 & OPEN RANGE & 755 & 925 & 1 & 30 & 90 & 2 & $\begin{array}{l}\text { COLLECTING } \\
\text { DATA }\end{array}$ & $\begin{array}{l}\text { RUNNING OPEN } \\
\text { RANGE, B2,B3 } \\
\text { BIDIRECTIONAL } \\
\text { E/W }\end{array}$ & GPS & LINEAR & $\mathrm{COOL}$ & DRY & 5 \\
\hline 20030515 & 645 & 1600 & OPEN RANGE & 925 & 945 & 0 & 20 & 20 & 5 & $\begin{array}{l}\text { DOWNTIME DUE } \\
\text { TO EQUIP } \\
\text { MAINT/CHECK }\end{array}$ & $\begin{array}{l}\text { CHECKING/ } \\
\text { DOWNLOADING } \\
\text { DATA }\end{array}$ & GPS & NA & $\mathrm{COOL}$ & DRY & 5 \\
\hline 20030515 & 645 & 1600 & OPEN RANGE & 945 & 1140 & 1 & 55 & 115 & 2 & $\begin{array}{l}\text { COLLECTING } \\
\text { DATA }\end{array}$ & $\begin{array}{l}\text { RUNNING OPEN } \\
\text { RANGE, B2,B3 } \\
\text { BIDIRECTIONAL } \\
\text { E/W }\end{array}$ & GPS & LINEAR & HOT & DRY & 5 \\
\hline 20030515 & 645 & 1600 & OPEN RANGE & 1140 & 1150 & 0 & 10 & 10 & 5 & $\begin{array}{l}\text { DOWNTIME DUE } \\
\text { TO EQUIP } \\
\text { MAINT/CHECK }\end{array}$ & $\begin{array}{l}\text { CHECKING/ } \\
\text { DOWNLOADING } \\
\text { DATA }\end{array}$ & GPS & NA & HOT & DRY & 5 \\
\hline 20030515 & 645 & 1600 & OPEN RANGE & 1150 & 1250 & 1 & & 60 & 3 & BREAK/LUNCH & CHOW & NA & NA & HOT & DRY & 5 \\
\hline 20030515 & 645 & 1600 & OPEN RANGE & 1250 & 1255 & 0 & 5 & 5 & 1 & $\begin{array}{l}\text { SET-UP/ } \\
\text { MOBILIZATION }\end{array}$ & SET UP ON C4,C5 & NA & NA & HOT & DRY & 5 \\
\hline 20030515 & 645 & 1600 & OPEN RANGE & 1255 & 1320 & 0 & 25 & 25 & 2 & $\begin{array}{l}\text { COLLECTING } \\
\text { DATA }\end{array}$ & $\begin{array}{l}\text { RUNNING OPEN } \\
\text { RANGE, C4,C5 } \\
\text { BIDIRECTIONAL } \\
\text { E/W }\end{array}$ & GPS & LINEAR & HOT & DRY & 5 \\
\hline 20030515 & 645 & 1600 & OPEN RANGE & 1320 & 1325 & 0 & 5 & 5 & 4 & $\begin{array}{l}\text { DOWNTIME DUE } \\
\text { TO EQUIP } \\
\text { FAILURE }\end{array}$ & $\begin{array}{l}\text { COMMUNICATION } \\
\text { ERROR INFIELD } \\
\text { COMPUTOR }\end{array}$ & GPS & NA & HOT & DRY & 5 \\
\hline 20030515 & 645 & 1600 & OPEN RANGE & 1325 & 1330 & & 5 & 5 & 5 & $\begin{array}{l}\text { DOWNTIME DUE } \\
\text { TO EQUIP } \\
\text { MAINT/CHECK }\end{array}$ & $\begin{array}{l}\text { CHANGE OUT } \\
\text { FIELD } \\
\text { COMPUTORS }\end{array}$ & GPS & NA & HOT & DRY & 5 \\
\hline 20030515 & 645 & 1600 & OPEN RANGE & 1330 & 1530 & 2 & 0 & 120 & 2 & $\begin{array}{l}\text { COLLECTING } \\
\text { DATA }\end{array}$ & $\begin{array}{l}\text { RUNNING OPEN } \\
\text { RANGE, C4,C5 } \\
\text { BIDIRECTIONAL } \\
\text { E/W }\end{array}$ & GPS & LINEAR & HOT & DRY & 5 \\
\hline 20030515 & 645 & 1600 & OPEN RANGE & 1530 & 1600 & 0 & 30 & 30 & 1 & $\begin{array}{l}\text { SET-UP/ } \\
\text { MOBILIZATION }\end{array}$ & $\begin{array}{l}\text { BREAKING DOWN } \\
\text { EQUIPMENT EOD }\end{array}$ & NA & NA & HOT & DRY & 5 \\
\hline 20030516 & 640 & 1600 & OPEN RANGE & 640 & 655 & 0 & 15 & 15 & 1 & $\begin{array}{l}\text { SET-UP/ } \\
\text { MOBILIZATION }\end{array}$ & $\begin{array}{l}\text { SETTING UP } \\
\text { EQUIPMENT }\end{array}$ & NA & NA & $\mathrm{COOL}$ & DRY & 4 \\
\hline
\end{tabular}




\begin{tabular}{|c|c|c|c|c|c|c|c|c|c|c|c|c|c|c|c|c|}
\hline \multirow{2}{*}{\begin{tabular}{|l} 
Date \\
20030516
\end{tabular}} & \multirow{2}{*}{ 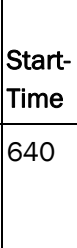 } & \multirow{2}{*}{ 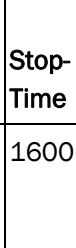 } & \multirow{2}{*}{$\begin{array}{l}\text { Area Tested } \\
\text { OPEN RANGE }\end{array}$} & \multirow{2}{*}{\begin{tabular}{|l|}
$\begin{array}{l}\text { Status } \\
\text { Start } \\
\text { Time }\end{array}$ \\
655 \\
\end{tabular}} & \multirow{2}{*}{\begin{tabular}{|l|}
$\begin{array}{l}\text { Status } \\
\text { Stop } \\
\text { Time }\end{array}$ \\
700 \\
\end{tabular}} & \multirow{2}{*}{$\begin{array}{l}\text { hr } \\
0\end{array}$} & \multirow{2}{*}{\begin{tabular}{|l|}
$\min$ \\
5
\end{tabular}} & \multirow{2}{*}{ 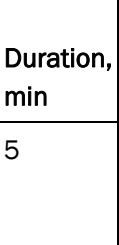 } & \multirow{2}{*}{\begin{tabular}{|l|} 
Op \\
Stat \\
Code \\
2 \\
\end{tabular}} & \multirow{2}{*}{ 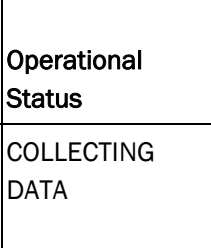 } & \multirow{2}{*}{$\begin{array}{l}\text { Operational } \\
\text { Status-Comments } \\
\text { EQUIPMENT WAS } \\
\text { CALIBRATED } \\
\text { USING CAL BALL }\end{array}$} & \multirow{2}{*}{\begin{tabular}{|l|}
$\begin{array}{l}\text { Track } \\
\text { Method }\end{array}$ \\
GPS
\end{tabular}} & \multirow{2}{*}{\begin{tabular}{|l|} 
Pattern \\
NA
\end{tabular}} & \multicolumn{2}{|c|}{ Field Conditions } & \multirow{2}{*}{$\begin{array}{l}\text { No. of } \\
\text { People } \\
4\end{array}$} \\
\hline & & & & & & & & & & & & & & $\mathrm{COOL}$ & DRY & \\
\hline 20030516 & 640 & 1600 & OPEN RANGE & 700 & 825 & 1 & 25 & 85 & 2 & $\begin{array}{l}\text { COLLECTING } \\
\text { DATA }\end{array}$ & $\begin{array}{l}\text { RUNNING OPEN } \\
\text { RANGE, C4,C5 } \\
\text { BIDIRECTIONAL } \\
\text { E/W }\end{array}$ & GPS & LINEAR & $\mathrm{COOL}$ & DRY & 4 \\
\hline 20030516 & 640 & 1600 & OPEN RANGE & 825 & 850 & 0 & 25 & 25 & 5 & $\begin{array}{l}\text { DOWNTIME DUE } \\
\text { TO EQUIP } \\
\text { MAINT/CHECK }\end{array}$ & $\begin{array}{l}\text { CHECKING/ } \\
\text { DOWNLOADING } \\
\text { DATA }\end{array}$ & GPS & NA & $\mathrm{COOL}$ & DRY & 4 \\
\hline 20030516 & 640 & 1600 & OPEN RANGE & 850 & 900 & 0 & 10 & 10 & 1 & $\begin{array}{l}\text { SET-UP/ } \\
\text { MOBILIZATION }\end{array}$ & SET UP ON D3 & NA & NA & $\mathrm{COOL}$ & DRY & 4 \\
\hline 20030516 & 640 & 1600 & OPEN RANGE & 900 & 1110 & 2 & 10 & 130 & 2 & $\begin{array}{l}\text { COLLECTING } \\
\text { DATA }\end{array}$ & $\begin{array}{l}\text { RUNNING OPEN } \\
\text { RANGE, D3 } \\
\text { BIDIRECTIONAL } \\
\text { E/W }\end{array}$ & GPS & LINEAR & HOT & DRY & 4 \\
\hline 20030516 & 640 & 1600 & OPEN RANGE & 1110 & 1125 & 0 & 15 & 15 & 5 & $\begin{array}{l}\text { DOWNTIME DUE } \\
\text { TO EQUIP } \\
\text { MAINT/CHECK }\end{array}$ & $\begin{array}{l}\text { CHECKING/ } \\
\text { DOWNLOADING } \\
\text { DATA }\end{array}$ & GPS & NA & HOT & DRY & 4 \\
\hline 20030516 & 640 & 1600 & OPEN RANGE & 1125 & 1235 & 1 & 10 & 70 & 3 & BREAK/LUNCH & CHOW & NA & NA & HOT & DRY & 4 \\
\hline 20030516 & 640 & 1600 & OPEN RANGE & 1235 & 1330 & 0 & 55 & 55 & 2 & $\begin{array}{l}\text { COLLECTING } \\
\text { DATA }\end{array}$ & $\begin{array}{l}\text { RUNNING OPEN } \\
\text { RANGE, D3 } \\
\text { BIDIRECTIONAL } \\
\text { E/W }\end{array}$ & GPS & LINEAR & HOT & DRY & 4 \\
\hline 20030516 & 640 & 1600 & OPEN RANGE & 1330 & 1410 & 0 & 40 & 40 & 3 & BREAK/LUNCH & BREAK & NA & NA & HOT & DRY & 4 \\
\hline 20030516 & 640 & 1600 & OPEN RANGE & 1410 & 1515 & 1 & 5 & 65 & 2 & $\begin{array}{l}\text { COLLECTING } \\
\text { DATA }\end{array}$ & $\begin{array}{l}\text { RUNNING OPEN } \\
\text { RANGE, D3 } \\
\text { BIDIRECTIONAL } \\
\text { E/W }\end{array}$ & GPS & LINEAR & HOT & DRY & 4 \\
\hline 20030516 & 640 & 1600 & OPEN RANGE & 1515 & 1530 & 0 & 15 & 15 & 5 & $\begin{array}{l}\text { DOWNTIME DUE } \\
\text { TO EQUIP } \\
\text { MAINT/CHECK }\end{array}$ & $\begin{array}{l}\text { CHECKING/ } \\
\text { DOWNLOADING } \\
\text { DATA }\end{array}$ & GPS & NA & HOT & DRY & 4 \\
\hline 20030516 & 640 & 1600 & OPEN RANGE & 1530 & 1600 & 0 & 30 & 30 & 1 & $\begin{array}{l}\text { SET-UP/ } \\
\text { MOBILIZATION }\end{array}$ & $\begin{array}{l}\text { BREAKING DOWN } \\
\text { EQUIPMENT EOD }\end{array}$ & NA & NA & HOT & DRY & 4 \\
\hline 20030517 & 630 & 1430 & OPEN RANGE & 630 & 715 & 0 & 45 & 45 & 1 & $\begin{array}{l}\text { SET-UP/ } \\
\text { MOBILIZATION }\end{array}$ & $\begin{array}{l}\text { SETTING UP } \\
\text { EQUIPMENT }\end{array}$ & NA & NA & HOT & DRY & 4 \\
\hline 20030517 & 630 & 1430 & OPEN RANGE & 715 & 720 & 0 & 5 & 5 & 2 & $\begin{array}{l}\text { COLLECTING } \\
\text { DATA }\end{array}$ & $\begin{array}{l}\text { EQUIPMENT WAS } \\
\text { CALIBRATED } \\
\text { USING CAL BALL }\end{array}$ & GPS & NA & HOT & DRY & 4 \\
\hline 20030517 & 630 & 1430 & OPEN RANGE & 720 & 825 & 1 & 5 & 65 & 2 & $\begin{array}{l}\text { COLLECTING } \\
\text { DATA }\end{array}$ & $\begin{array}{l}\text { RUNNING OPEN } \\
\text { RANGE, D2 } \\
\text { BIDIRECTIONAL } \\
\text { E/W }\end{array}$ & GPS & LINEAR & HOT & DRY & 4 \\
\hline 20030517 & 630 & 1430 & OPEN RANGE & 825 & 921 & 0 & 56 & 56 & 5 & $\begin{array}{l}\text { DOWNTIME DUE } \\
\text { TO EQUIP } \\
\text { MAINT/CHECK }\end{array}$ & $\begin{array}{l}\text { CHECKING/ } \\
\text { DOWNLOADING } \\
\text { DATA }\end{array}$ & GPS & NA & HOT & DRY & 4 \\
\hline
\end{tabular}




\begin{tabular}{|c|c|c|c|c|c|c|c|c|c|c|c|c|c|c|c|c|}
\hline \multirow{2}{*}{\begin{tabular}{|l} 
Date \\
20030517
\end{tabular}} & \multirow{2}{*}{\begin{tabular}{|l|} 
Start- \\
Time
\end{tabular}} & \multirow{2}{*}{\begin{tabular}{|l|} 
Stop- \\
Time \\
1430 \\
\end{tabular}} & \multirow{2}{*}{$\begin{array}{l}\text { Area Tested } \\
\text { OPEN RANGE }\end{array}$} & \multirow{2}{*}{\begin{tabular}{|l|}
$\begin{array}{l}\text { Status } \\
\text { Start } \\
\text { Time }\end{array}$ \\
921 \\
\end{tabular}} & \multirow{2}{*}{\begin{tabular}{|l|}
$\begin{array}{l}\text { Status } \\
\text { Stop } \\
\text { Time }\end{array}$ \\
1040
\end{tabular}} & \multirow{2}{*}{$\begin{array}{l}\text { hr } \\
1\end{array}$} & \multirow{2}{*}{\begin{tabular}{|l|}
$\min$ \\
19
\end{tabular}} & \multirow{2}{*}{$\begin{array}{l}\text { Duration, } \\
\min \end{array}$} & \multirow{2}{*}{\begin{tabular}{|l} 
Op \\
Stat \\
Code \\
2
\end{tabular}} & \multirow{2}{*}{\begin{tabular}{|l} 
Operational \\
Status
\end{tabular}} & \multirow{2}{*}{\begin{tabular}{|l} 
Operational \\
Status-Comments \\
RUNNING OPEN \\
RANGE, B5 \\
BIDIRECTIONAL \\
E/W
\end{tabular}} & \multirow{2}{*}{\begin{tabular}{|l|} 
Track \\
Method \\
GPS \\
\end{tabular}} & \multirow{2}{*}{\begin{tabular}{|l|} 
Pattern \\
LINEAR
\end{tabular}} & \multicolumn{2}{|c|}{ Field Conditions } & \multirow{2}{*}{\begin{tabular}{|l} 
No. of \\
People
\end{tabular}} \\
\hline & & & & & & & & & & & & & & HOT & DRY & \\
\hline 20030517 & 630 & 1430 & OPEN RANGE & 1040 & 1045 & 0 & 5 & 5 & 5 & $\begin{array}{l}\text { DOWNTIME DUE } \\
\text { TO EQUIP } \\
\text { MAINT/CHECK }\end{array}$ & $\begin{array}{l}\text { CHECKING/ } \\
\text { DOWNLOADING } \\
\text { DATA }\end{array}$ & GPS & NA & HOT & DRY & 4 \\
\hline 20030517 & 630 & 1430 & OPEN RANGE & 1045 & 1120 & 0 & 35 & 35 & 3 & BREAK/LUNCH & CHOW & NA & NA & HOT & DRY & 4 \\
\hline 20030517 & 630 & 1430 & OPEN RANGE & 1120 & 1230 & 1 & 10 & 70 & 2 & $\begin{array}{l}\text { COLLECTING } \\
\text { DATA }\end{array}$ & $\begin{array}{l}\text { RUNNING OPEN } \\
\text { RANGE, B5 } \\
\text { BIDIRECTIONAL } \\
\text { E/W }\end{array}$ & GPS & LINEAR & HOT & DRY & 3 \\
\hline 20030517 & 630 & 1430 & OPEN RANGE & 1230 & 1245 & 0 & 15 & 15 & 5 & $\begin{array}{l}\text { DOWNTIME DUE } \\
\text { TO EQUIP } \\
\text { MAINT/CHECK }\end{array}$ & $\begin{array}{l}\text { CHECKING/ } \\
\text { DOWNLOADING } \\
\text { DATA }\end{array}$ & GPS & NA & HOT & DRY & 3 \\
\hline 20030517 & 630 & 1430 & OPEN RANGE & 1245 & 1335 & 0 & 50 & 50 & 3 & BREAK/LUNCH & BREAK & NA & NA & HOT & DRY & 3 \\
\hline 20030517 & 630 & 1430 & OPEN RANGE & 1335 & 1400 & 0 & 25 & 25 & 2 & $\begin{array}{l}\text { COLLECTING } \\
\text { DATA }\end{array}$ & $\begin{array}{l}\text { CONDUCTED } \\
\text { EQUIPMENT } \\
\text { INTERFERENCE } \\
\text { TEST }\end{array}$ & GPS & NA & НОT & DRY & 3 \\
\hline 20030517 & 630 & 1430 & OPEN RANGE & 1400 & 1430 & 0 & 30 & 30 & 1 & $\begin{array}{l}\text { SET-UP/ } \\
\text { MOBILIZATION }\end{array}$ & $\begin{array}{l}\text { BREAKING DOWN } \\
\text { EQUIPMENT EOD }\end{array}$ & NA & NA & HOT & DRY & 3 \\
\hline 20030519 & 600 & 1430 & OPEN RANGE & 600 & 615 & 0 & 15 & 15 & 1 & $\begin{array}{l}\text { SET-UP/ } \\
\text { MOBILIZATION }\end{array}$ & $\begin{array}{l}\text { SETTING UP } \\
\text { EQUIPMENT }\end{array}$ & NA & NA & HOT & DRY & 4 \\
\hline 20030519 & 600 & 1430 & OPEN RANGE & 615 & 620 & 0 & 5 & 5 & 2 & $\begin{array}{l}\text { COLLECTING } \\
\text { DATA }\end{array}$ & $\begin{array}{l}\text { EQUIPMENT WAS } \\
\text { CALIBRATED } \\
\text { USING CAL BALL }\end{array}$ & GPS & NA & НОT & DRY & 4 \\
\hline 20030519 & 600 & 1430 & OPEN RANGE & 620 & 743 & 1 & 23 & 83 & 2 & $\begin{array}{l}\text { COLLECTING } \\
\text { DATA }\end{array}$ & $\begin{array}{l}\text { RUNNING OPEN } \\
\text { RANGE, B4 } \\
\text { BIDIRECTIONAL } \\
\text { E/W }\end{array}$ & GPS & LINEAR & HOT & DRY & 4 \\
\hline 20030519 & 600 & 1430 & OPEN RANGE & 743 & 815 & 0 & 32 & 32 & 5 & $\begin{array}{l}\text { DOWNTIME DUE } \\
\text { TO EQUIP } \\
\text { MAINT/CHECK }\end{array}$ & $\begin{array}{l}\text { CHECKING/ } \\
\text { DOWNLOADING } \\
\text { DATA }\end{array}$ & NA & NA & НOT & DRY & 4 \\
\hline 20030519 & 600 & 1430 & OPEN RANGE & 815 & 930 & 1 & 15 & 75 & 2 & $\begin{array}{l}\text { COLLECTING } \\
\text { DATA }\end{array}$ & $\begin{array}{l}\text { RUNNING OPEN } \\
\text { RANGE, B4 } \\
\text { BIDIRECTIONAL } \\
\text { E/W }\end{array}$ & GPS & LINEAR & HOT & DRY & 4 \\
\hline 20030519 & 600 & 1430 & OPEN RANGE & 930 & 945 & 0 & 15 & 15 & 5 & $\begin{array}{l}\text { DOWNTIME DUE } \\
\text { TO EQUIP } \\
\text { MAINT/CHECK }\end{array}$ & $\begin{array}{l}\text { CHECKING/ } \\
\text { DOWNLOADING } \\
\text { DATA }\end{array}$ & NA & NA & HOT & DRY & 4 \\
\hline 20030519 & 600 & 1430 & OPEN RANGE & 945 & 950 & 0 & 5 & 5 & 5 & $\begin{array}{l}\text { DOWNTIME DUE } \\
\text { TO EQUIP } \\
\text { MAINT/CHECK }\end{array}$ & $\begin{array}{l}\text { CHANGE OUT } \\
\text { BATTERY }\end{array}$ & NA & NA & HOT & DRY & 4 \\
\hline 20030519 & 600 & 1430 & OPEN RANGE & 950 & 955 & 0 & 5 & 5 & 3 & BREAK/LUNCH & BREAK & NA & NA & HOT & DRY & 4 \\
\hline
\end{tabular}




\begin{tabular}{|c|c|c|c|c|c|c|c|c|c|c|c|c|c|c|c|c|}
\hline \multirow{2}{*}{\begin{tabular}{|l} 
Date \\
20030519
\end{tabular}} & \multirow{2}{*}{\begin{tabular}{|l} 
Start \\
Time \\
600
\end{tabular}} & \multirow{2}{*}{ 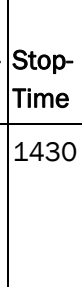 } & \multirow{2}{*}{$\begin{array}{l}\text { Area Tested } \\
\text { OPEN RANGE }\end{array}$} & \multirow{2}{*}{\begin{tabular}{|l|}
$\begin{array}{l}\text { Status } \\
\text { Start } \\
\text { Time }\end{array}$ \\
955
\end{tabular}} & \multirow{2}{*}{\begin{tabular}{|l|}
$\begin{array}{l}\text { Status } \\
\text { Stop } \\
\text { Time }\end{array}$ \\
1005 \\
\end{tabular}} & \multirow{2}{*}{\begin{tabular}{|l} 
hr \\
0
\end{tabular}} & \multirow{2}{*}{$\begin{array}{l}\min \\
10\end{array}$} & \multirow{2}{*}{\begin{tabular}{|l|} 
Duration, \\
$\min$
\end{tabular}} & \multirow{2}{*}{ 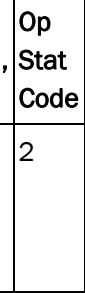 } & \multirow{2}{*}{\begin{tabular}{|l} 
Operational \\
Status
\end{tabular}} & \multirow{2}{*}{\begin{tabular}{|l} 
Operational \\
Status-Comments \\
RUNNING OPEN \\
RANGE, B4 \\
BIDIRECTIONAL \\
E/W
\end{tabular}} & \multirow{2}{*}{\begin{tabular}{|l|} 
Track \\
Method
\end{tabular}} & \multirow{2}{*}{\begin{tabular}{|l|} 
Pattern \\
LINEAR
\end{tabular}} & \multicolumn{2}{|c|}{ Field Conditions } & \multirow{2}{*}{\begin{tabular}{|l} 
No. of \\
People
\end{tabular}} \\
\hline & & & & & & & & & & & & & & HOT & DRY & \\
\hline 20030519 & 600 & 1430 & OPEN RANGE & 1005 & 1010 & 0 & 5 & 5 & 1 & $\begin{array}{l}\text { SET-UP/ } \\
\text { MOBILIZATION }\end{array}$ & $\begin{array}{l}\text { SET UP ON GRID } \\
\text { C2,C3 }\end{array}$ & NA & NA & HOT & DRY & 4 \\
\hline 20030519 & 600 & 1430 & OPEN RANGE & 1010 & 1024 & 0 & 14 & 14 & 5 & $\begin{array}{l}\text { DOWNTIME DUE } \\
\text { TO EQUIP } \\
\text { MAINT/CHECK }\end{array}$ & $\begin{array}{l}\text { CHECKING/ } \\
\text { DOWNLOADING } \\
\text { DATA }\end{array}$ & GPS & NA & HOT & DRY & 4 \\
\hline 20030519 & 600 & 1430 & OPEN RANGE & 1024 & 1130 & 1 & 6 & 66 & 2 & $\begin{array}{l}\text { COLLECTING } \\
\text { DATA }\end{array}$ & $\begin{array}{l}\text { RUNNING OPEN } \\
\text { RANGE, C2,C3 } \\
\text { BIDIRECTIONAL } \\
\text { E/W }\end{array}$ & GPS & LINEAR & HOT & DRY & 4 \\
\hline 20030519 & 600 & 1430 & OPEN RANGE & 1130 & 1145 & 0 & 15 & 15 & 5 & $\begin{array}{l}\text { DOWNTIME DUE } \\
\text { TO EQUIP } \\
\text { MAINT/CHECK }\end{array}$ & $\begin{array}{l}\text { CHECKING/ } \\
\text { DOWNLOADING } \\
\text { DATA }\end{array}$ & GPS & NA & HOT & DRY & 4 \\
\hline 20030519 & 600 & 1430 & OPEN RANGE & 1145 & 1310 & 1 & 25 & 85 & 3 & BREAK/LUNCH & CHOW/BREAK & NA & NA & HOT & DRY & 4 \\
\hline 20030519 & 600 & 1430 & OPEN RANGE & 1310 & 1410 & 1 & 0 & 60 & 2 & $\begin{array}{l}\text { COLLECTING } \\
\text { DATA }\end{array}$ & $\begin{array}{l}\text { RUNNING OPEN } \\
\text { RANGE, C2,C3 } \\
\text { BIDIRECTIONAL } \\
\text { E/W }\end{array}$ & GPS & LINEAR & HOT & DRY & 4 \\
\hline 20030519 & 600 & 1430 & OPEN RANGE & 1410 & 1420 & 0 & 10 & 10 & 5 & $\begin{array}{l}\text { DOWNTIME DUE } \\
\text { TO EQUIP } \\
\text { MAINT/CHECK }\end{array}$ & $\begin{array}{l}\text { CHECKING/ } \\
\text { DOWNLOADING } \\
\text { DATA }\end{array}$ & GPS & NA & HOT & DRY & 4 \\
\hline 20030519 & 600 & 1430 & OPEN RANGE & 1420 & 1430 & 0 & 10 & 10 & 1 & $\begin{array}{l}\text { SET-UP/ } \\
\text { MOBILIZATION }\end{array}$ & $\begin{array}{l}\text { BREAKING DOWN } \\
\text { EQUIPMENT EOD }\end{array}$ & NA & NA & HOT & DRY & 4 \\
\hline 20030520 & 530 & 1310 & OPEN RANGE & 530 & 545 & 0 & 15 & 15 & 1 & $\begin{array}{l}\text { SET-UP/ } \\
\text { MOBILIZATION }\end{array}$ & $\begin{array}{l}\text { SETTING UP } \\
\text { EQUIPMENT }\end{array}$ & NA & NA & HOT & DRY & 4 \\
\hline 20030520 & 530 & 1310 & OPEN RANGE & 545 & 549 & 0 & 4 & 4 & 2 & $\begin{array}{l}\text { COLLECTING } \\
\text { DATA }\end{array}$ & $\begin{array}{l}\text { EQUIPMENT WAS } \\
\text { CALIBRATED } \\
\text { USING CAL BALL }\end{array}$ & GPS & NA & HOT & DRY & 4 \\
\hline 20030520 & 530 & 1310 & OPEN RANGE & 549 & 718 & 1 & 29 & 89 & 2 & $\begin{array}{l}\text { COLLECTING } \\
\text { DATA }\end{array}$ & $\begin{array}{l}\text { RUNNING OPEN } \\
\text { RANGE, C2,C3 } \\
\text { BIDIRECTIONAL } \\
\text { E/W }\end{array}$ & GPS & LINEAR & HOT & DRY & 4 \\
\hline 20030520 & 530 & 1310 & OPEN RANGE & 718 & 738 & 0 & 20 & 20 & 5 & $\begin{array}{l}\text { DOWNTIME DUE } \\
\text { TO EQUIP } \\
\text { MAINT/CHECK }\end{array}$ & $\begin{array}{l}\text { CHECKING/ } \\
\text { DOWNLOADING } \\
\text { DATA }\end{array}$ & GPS & NA & HOT & DRY & 4 \\
\hline 20030520 & 530 & 1310 & OPEN RANGE & 738 & 805 & 0 & 27 & 27 & 3 & BREAK/LUNCH & BREAK & NA & NA & HOT & DRY & 4 \\
\hline 20030520 & 530 & 1310 & OPEN RANGE & 805 & 847 & 0 & 42 & 42 & 2 & $\begin{array}{l}\text { COLLECTING } \\
\text { DATA }\end{array}$ & $\begin{array}{l}\text { RUNNING OPEN } \\
\text { RANGE, C2,C3 } \\
\text { BIDIRECTIONAL } \\
\text { E/W }\end{array}$ & GPS & LINEAR & HOT & DRY & 4 \\
\hline 20030520 & 530 & 1310 & OPEN RANGE & 847 & 900 & 0 & 13 & 13 & 5 & $\begin{array}{l}\text { DOWNTIME DUE } \\
\text { TO EQUIP } \\
\text { MAINT/CHECK }\end{array}$ & $\begin{array}{l}\text { CHECKING/ } \\
\text { DOWNLOADING } \\
\text { DATA }\end{array}$ & GPS & NA & HOT & DRY & 4 \\
\hline
\end{tabular}




\begin{tabular}{|c|c|c|c|c|c|c|c|c|c|c|c|c|c|c|c|c|}
\hline \multirow{2}{*}{\begin{tabular}{|l} 
Date \\
20030520
\end{tabular}} & \multirow{2}{*}{$\begin{array}{l}\text { Start- } \\
\text { Time } \\
530\end{array}$} & \multirow{2}{*}{ 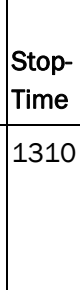 } & \multirow{2}{*}{$\begin{array}{l}\text { Area Tested } \\
\text { OPEN RANGE }\end{array}$} & \multirow{2}{*}{\begin{tabular}{|l|}
$\begin{array}{l}\text { Status } \\
\text { Start } \\
\text { Time }\end{array}$ \\
900
\end{tabular}} & \multirow{2}{*}{\begin{tabular}{|l|}
$\begin{array}{l}\text { Status } \\
\text { Stop } \\
\text { Time }\end{array}$ \\
937 \\
\end{tabular}} & \multirow{2}{*}{$\begin{array}{l}\text { hr } \\
0\end{array}$} & \multirow{2}{*}{$\begin{array}{l}\min \\
37\end{array}$} & \multirow{2}{*}{$\begin{array}{l}\text { Duration, } \\
\min \\
37\end{array}$} & \multirow{2}{*}{\begin{tabular}{|l|} 
Op \\
Stat \\
Code
\end{tabular} \mid} & \multirow{2}{*}{\begin{tabular}{|l} 
Operational \\
Status
\end{tabular}} & \multirow{2}{*}{$\begin{array}{l}\text { Operational } \\
\text { Status-Comments } \\
\text { RUNNING OPEN } \\
\text { RANGE, C2,C3 } \\
\text { BIDIRECTIONAL } \\
\text { E/W }\end{array}$} & \multirow{2}{*}{\begin{tabular}{|l|} 
Track \\
Method
\end{tabular}} & \multirow{2}{*}{\begin{tabular}{|l|} 
Pattern \\
LINEAR
\end{tabular}} & \multicolumn{2}{|c|}{ Field Conditions } & \multirow{2}{*}{$\begin{array}{l}\text { No. of } \\
\text { People } \\
4\end{array}$} \\
\hline & & & & & & & & & & & & & & HOT & DRY & \\
\hline 20030520 & 530 & 1310 & OPEN RANGE & 937 & 952 & 0 & 15 & 15 & 5 & $\begin{array}{l}\text { DOWNTIME DUE } \\
\text { TO EQUIP } \\
\text { MAINT/CHECK }\end{array}$ & $\begin{array}{l}\text { CHECKING/ } \\
\text { DOWNLOADING } \\
\text { DATA }\end{array}$ & GPS & NA & HOT & DRY & 4 \\
\hline 20030520 & 530 & 1310 & OPEN RANGE & 952 & 1012 & 0 & 20 & 20 & 3 & BREAK/LUNCH & BREAK & NA & NA & HOT & DRY & 4 \\
\hline 20030520 & 530 & 1310 & $\begin{array}{l}\text { YUMA } \\
\text { EXTREME }\end{array}$ & 1012 & 1024 & 0 & 12 & 12 & 1 & $\begin{array}{l}\text { SET-UP/ } \\
\text { MOBILIZATION }\end{array}$ & $\begin{array}{l}\text { SET UP IN YUMA } \\
\text { EXTREME }\end{array}$ & NA & NA & HOT & DRY & 4 \\
\hline 20030520 & 530 & 1310 & $\begin{array}{l}\text { YUMA } \\
\text { EXTREME }\end{array}$ & 1024 & 1111 & 0 & 47 & 47 & 2 & $\begin{array}{l}\text { COLLECTING } \\
\text { DATA }\end{array}$ & $\begin{array}{l}\text { RUNNING YUMA } \\
\text { EXTREME } \\
\text { BIDIRECTIONAL } \\
\text { NORTH/SOUTH }\end{array}$ & GPS & LINEAR & HOT & DRY & 4 \\
\hline 20030520 & 530 & 1310 & $\begin{array}{l}\text { YUMA } \\
\text { EXTREME }\end{array}$ & 1111 & 1130 & 0 & 19 & 19 & 5 & $\begin{array}{l}\text { DOWNTIME DUE } \\
\text { TO EQUIP } \\
\text { MAINT/CHECK }\end{array}$ & $\begin{array}{l}\text { CHECKING/ } \\
\text { DOWNLOADING } \\
\text { DATA }\end{array}$ & GPS & NA & HOT & DRY & 4 \\
\hline 20030520 & 530 & 1310 & $\begin{array}{l}\text { YUMA } \\
\text { EXTREME }\end{array}$ & 1130 & 1230 & 1 & 0 & 60 & 3 & BREAK/LUNCH & LUNCH & NA & NA & HOT & DRY & 4 \\
\hline 20030520 & 530 & 1310 & $\begin{array}{l}\text { YUMA } \\
\text { EXTREME }\end{array}$ & 1230 & 1245 & 0 & 15 & 15 & 1 & $\begin{array}{l}\text { SET-UP/ } \\
\text { MOBILIZATION }\end{array}$ & SETUP & NA & NA & HOT & DRY & 4 \\
\hline 20030520 & 530 & 1310 & $\begin{array}{l}\text { YUMA } \\
\text { EXTREME }\end{array}$ & 1245 & 1248 & 0 & 3 & 3 & 2 & $\begin{array}{l}\text { COLLECTING } \\
\text { DATA }\end{array}$ & $\begin{array}{l}\text { EQUIPMENT WAS } \\
\text { CAL-BRATED } \\
\text { USING CAL BALL }\end{array}$ & GPS & NA & HOT & DRY & 4 \\
\hline 20030520 & 530 & 1310 & $\begin{array}{l}\text { YUMA } \\
\text { EXTREME }\end{array}$ & 1248 & 1255 & 0 & 7 & 7 & 2 & $\begin{array}{l}\text { COLLECTING } \\
\text { DATA }\end{array}$ & $\begin{array}{l}\text { RUNNING YUMA } \\
\text { EXTREME } \\
\text { BIDIRECTIONAL } \\
\text { NORTH/SOUTH }\end{array}$ & GPS & LINEAR & HOT & DRY & 4 \\
\hline 20030520 & 530 & 1310 & $\begin{array}{l}\text { YUMA } \\
\text { EXTREME }\end{array}$ & 1255 & 1300 & 0 & 5 & 5 & 4 & $\begin{array}{l}\text { DOWNTIME DUE } \\
\text { TO EQUIP } \\
\text { FAILURE }\end{array}$ & $\begin{array}{l}\text { FIELD COMPUTER } \\
\text { OVERHEAT/FAILED }\end{array}$ & NA & NA & HOT & DRY & 4 \\
\hline 20030520 & 530 & 1310 & $\begin{array}{l}\text { YUMA } \\
\text { EXTREME }\end{array}$ & 1300 & 1310 & 0 & 10 & 10 & 1 & $\begin{array}{l}\text { SET-UP/ } \\
\text { MOBILIZATION }\end{array}$ & $\begin{array}{l}\text { BREAKING DOWN } \\
\text { EQUIPMENT EOD }\end{array}$ & NA & NA & HOT & DRY & 4 \\
\hline 20030521 & 530 & 1500 & $\begin{array}{l}\text { YUMA } \\
\text { EXTREME }\end{array}$ & 530 & 550 & 0 & 20 & 20 & 1 & $\begin{array}{l}\text { SET-UP/ } \\
\text { MOBILIZATION }\end{array}$ & $\begin{array}{l}\text { SETTING UP } \\
\text { EQUIPMENT }\end{array}$ & NA & NA & HOT & DRY & 3 \\
\hline 20030521 & 530 & 1500 & $\begin{array}{l}\text { YUMA } \\
\text { EXTREME }\end{array}$ & 550 & 600 & 0 & 10 & 10 & 2 & $\begin{array}{l}\text { COLLECTING } \\
\text { DATA }\end{array}$ & $\begin{array}{l}\text { EQUIPMENT WAS } \\
\text { CALIBRATED } \\
\text { USING CAL BALL }\end{array}$ & GPS & NA & HOT & DRY & 3 \\
\hline 20030521 & 530 & 1500 & $\begin{array}{l}\text { YUMA } \\
\text { EXTREME }\end{array}$ & 600 & 605 & 0 & 5 & 5 & 2 & $\begin{array}{l}\text { COLLECTING } \\
\text { DATA }\end{array}$ & $\begin{array}{l}\text { RUNNING YUMA } \\
\text { EXTREME } \\
\text { BIDIRECTIONAL } \\
\text { NORTH/SOUTH }\end{array}$ & GPS & LINEAR & HOT & DRY & 3 \\
\hline 20030521 & 530 & 1500 & $\begin{array}{l}\text { YUMA } \\
\text { EXTREME }\end{array}$ & 605 & 614 & 0 & 9 & 9 & 5 & $\begin{array}{l}\text { DOWNTIME DUE } \\
\text { TO EQUIP } \\
\text { MAINT/CHECK }\end{array}$ & $\begin{array}{l}\text { CHECKING/ } \\
\text { DOWNLOADING } \\
\text { DATA }\end{array}$ & GPS & NA & HOT & DRY & 3 \\
\hline
\end{tabular}




\begin{tabular}{|c|c|c|c|c|c|c|c|c|c|c|c|c|c|c|c|c|}
\hline \multirow{2}{*}{\begin{tabular}{|l|} 
Date \\
20030521
\end{tabular}} & \multirow{2}{*}{\begin{tabular}{|l} 
Start- \\
Time
\end{tabular}} & \multirow{2}{*}{\begin{tabular}{|l|} 
Stop- \\
Time
\end{tabular}} & \multirow{2}{*}{\begin{tabular}{|l} 
Area Tested \\
YUMA \\
EXTREME
\end{tabular}} & \multirow{2}{*}{\begin{tabular}{|l|}
$\begin{array}{l}\text { Status } \\
\text { Start } \\
\text { Time }\end{array}$ \\
614
\end{tabular}} & \multirow{2}{*}{\begin{tabular}{|l|} 
Status \\
Stop \\
Time
\end{tabular}} & \multirow{2}{*}{$\begin{array}{l}\text { hr } \\
1\end{array}$} & \multirow{2}{*}{$\begin{array}{l}\min \\
36\end{array}$} & \multirow{2}{*}{\begin{tabular}{|l|} 
Duration, \\
$\min$
\end{tabular}} & \multirow{2}{*}{ 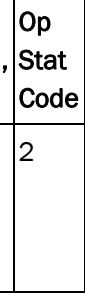 } & \multirow{2}{*}{\begin{tabular}{|l} 
Operational \\
Status
\end{tabular}} & \multirow{2}{*}{\begin{tabular}{|l} 
Operational \\
Status-Comments \\
RUNNING YUMA \\
EXTREME \\
BIDIRECTIONAL \\
NORTH/SOUTH
\end{tabular}} & \multirow{2}{*}{\begin{tabular}{|l|} 
Track \\
Method \\
GPS \\
\end{tabular}} & \multirow{2}{*}{\begin{tabular}{|l|} 
Pattern \\
LINEAR
\end{tabular}} & \multicolumn{2}{|c|}{ Field Conditions } & \multirow{2}{*}{\begin{tabular}{|l} 
No. of \\
People
\end{tabular}} \\
\hline & & & & & & & & & & & & & & HOT & DRY & \\
\hline 20030521 & 530 & 1500 & $\begin{array}{l}\text { YUMA } \\
\text { EXTREME }\end{array}$ & 750 & 810 & 0 & 20 & 20 & 5 & $\begin{array}{l}\text { DOWNTIME DUE } \\
\text { TO EQUIP } \\
\text { MAINT/CHECK }\end{array}$ & $\begin{array}{l}\text { CHECKING/ } \\
\text { DOWNLOADING } \\
\text { DATA }\end{array}$ & GPS & NA & HOT & DRY & 3 \\
\hline 20030521 & 530 & 1500 & $\begin{array}{l}\text { YUMA } \\
\text { EXTREME }\end{array}$ & 810 & 820 & 0 & 10 & 10 & 3 & BREAK/LUNCH & BREAK & NA & NA & HOT & DRY & 3 \\
\hline 20030521 & 530 & 1500 & $\begin{array}{l}\text { YUMA } \\
\text { EXTREME }\end{array}$ & 820 & 850 & 0 & 30 & 30 & 2 & $\begin{array}{l}\text { COLLECTING } \\
\text { DATA }\end{array}$ & $\begin{array}{l}\text { RUNNING YUMA } \\
\text { EXTREME } \\
\text { BIDIRECTIONAL } \\
\text { NORTH/SOUTH }\end{array}$ & GPS & LINEAR & HOT & DRY & 3 \\
\hline 20030521 & 530 & 1500 & $\begin{array}{l}\text { YUMA } \\
\text { EXTREME }\end{array}$ & 850 & 920 & 0 & 30 & 30 & 5 & $\begin{array}{l}\text { DOWNTIME DUE } \\
\text { TO EQUIP } \\
\text { MAINT/CHECK }\end{array}$ & $\begin{array}{l}\text { CHECKING/ } \\
\text { DOWNLOADING } \\
\text { DATA }\end{array}$ & GPS & NA & HOT & DRY & 3 \\
\hline 20030521 & 530 & 1500 & $\begin{array}{l}\text { MOGUL } \\
\text { AREA }\end{array}$ & 920 & 930 & 0 & 10 & 10 & 1 & $\begin{array}{l}\text { SET-UP/ } \\
\text { MOBILIZATION }\end{array}$ & $\begin{array}{l}\text { SET UP IN MOGUL } \\
\text { AREA }\end{array}$ & NA & NA & HOT & DRY & 3 \\
\hline 20030521 & 530 & 1500 & $\begin{array}{l}\text { MOGUL } \\
\text { AREA }\end{array}$ & 930 & 1040 & 1 & 10 & 70 & 2 & $\begin{array}{l}\text { COLLECTING } \\
\text { DATA }\end{array}$ & $\begin{array}{l}\text { RUNNING MOGUL } \\
\text { AREA, B- } \\
\text { DIRECTIONAL N / } \\
\text { SOUTH }\end{array}$ & GPS & LINEAR & HOT & DRY & 3 \\
\hline 20030521 & 530 & 1500 & $\begin{array}{l}\text { MOGUL } \\
\text { AREA }\end{array}$ & 1040 & 1100 & 0 & 20 & 20 & 5 & $\begin{array}{l}\text { DOWNTIME DUE } \\
\text { TO EQUIP } \\
\text { MAINT/CHECK }\end{array}$ & $\begin{array}{l}\text { CHECKING/ } \\
\text { DOWNLOADING } \\
\text { DATA }\end{array}$ & GPS & NA & HOT & DRY & 3 \\
\hline 20030521 & 530 & 1500 & $\begin{array}{l}\text { MOGUL } \\
\text { AREA }\end{array}$ & 1100 & 1158 & 0 & 58 & 58 & 2 & $\begin{array}{l}\text { COLLECTING } \\
\text { DATA }\end{array}$ & $\begin{array}{l}\text { RUNNING MOGUL } \\
\text { AREA, } \\
\text { BIDIRECTIONAL } \\
\text { NORTH/SOUTH }\end{array}$ & GPS & LINEAR & HOT & DRY & 3 \\
\hline 20030521 & 530 & 1500 & $\begin{array}{l}\text { MOGUL } \\
\text { AREA }\end{array}$ & 1158 & 1210 & 0 & 12 & 12 & 4 & $\begin{array}{l}\text { DOWNTIME DUE } \\
\text { TO EQUIP } \\
\text { FAILURE }\end{array}$ & $\begin{array}{l}\text { GPS MOUNT } \\
\text { BROKE, } \\
\text { OPERATOR ERROR }\end{array}$ & NA & NA & HOT & DRY & 3 \\
\hline 20030521 & 530 & 1500 & $\begin{array}{l}\text { MOGUL } \\
\text { AREA }\end{array}$ & 1210 & 1230 & 0 & 20 & 20 & 5 & $\begin{array}{l}\text { DOWNTIME DUE } \\
\text { TO EQUIP } \\
\text { MAINT/CHECK }\end{array}$ & $\begin{array}{l}\text { CHECKING/ } \\
\text { DOWNLOADING } \\
\text { DATA }\end{array}$ & GPS & NA & HOT & DRY & 3 \\
\hline 20030521 & 530 & 1500 & $\begin{array}{l}\text { MOGUL } \\
\text { AREA }\end{array}$ & 1230 & 1237 & 0 & 7 & 7 & 2 & $\begin{array}{l}\text { COLLECTING } \\
\text { DATA }\end{array}$ & $\begin{array}{l}\text { EQUIPMENT WAS } \\
\text { CALIBRATED } \\
\text { USING CAL BALL }\end{array}$ & GPS & NA & HOT & DRY & 3 \\
\hline 20030521 & 530 & 1500 & $\begin{array}{l}\text { MOGUL } \\
\text { AREA }\end{array}$ & 1237 & 1322 & 0 & 45 & 45 & 2 & $\begin{array}{l}\text { COLLECTING } \\
\text { DATA }\end{array}$ & $\begin{array}{l}\text { RUNNING MOGUL } \\
\text { AREA, } \\
\text { BIDIRECTIONAL } \\
\text { NORTH/SOUTH }\end{array}$ & GPS & LINEAR & HOT & DRY & 3 \\
\hline 20030521 & 530 & 1500 & $\begin{array}{l}\text { MOGUL } \\
\text { AREA }\end{array}$ & 1322 & 1335 & 0 & 13 & 13 & 5 & $\begin{array}{l}\text { DOWNTIME DUE } \\
\text { TO EQUIP } \\
\text { MAINT/CHECK }\end{array}$ & $\begin{array}{l}\text { CHECKING/ } \\
\text { DOWNLOADING } \\
\text { DATA }\end{array}$ & GPS & NA & HOT & DRY & 3 \\
\hline 20030521 & 530 & 1500 & $\begin{array}{l}\text { MOGUL } \\
\text { AREA }\end{array}$ & 1335 & 1445 & 1 & 10 & 70 & 2 & $\begin{array}{l}\text { COLLECTING } \\
\text { DATA }\end{array}$ & $\begin{array}{l}\text { RUNNING MOGUL } \\
\text { AREA, } \\
\text { BIDIRECTIONAL } \\
\text { NORTH/SOUTH }\end{array}$ & GPS & LINEAR & HOT & DRY & 3 \\
\hline
\end{tabular}




\begin{tabular}{|c|c|c|c|c|c|c|c|c|c|c|c|c|c|c|c|c|}
\hline \multirow{2}{*}{\begin{tabular}{|l} 
Date \\
20030521
\end{tabular}} & \multirow{2}{*}{\begin{tabular}{|l|} 
Start- \\
Time
\end{tabular}} & \multirow{2}{*}{\begin{tabular}{|l|} 
Stop- \\
Time
\end{tabular}} & \multirow{2}{*}{$\begin{array}{l}\text { Area Tested } \\
\text { MOGUL } \\
\text { AREA }\end{array}$} & \multirow{2}{*}{ 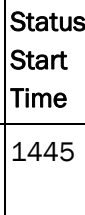 } & \multirow{2}{*}{\begin{tabular}{|l|}
$\begin{array}{l}\text { Status } \\
\text { Stop } \\
\text { Time }\end{array}$ \\
1500
\end{tabular}} & \multirow{2}{*}{$\begin{array}{l}\text { hr } \\
0\end{array}$} & \multirow{2}{*}{$\begin{array}{l}\min \\
15\end{array}$} & \multirow{2}{*}{$\begin{array}{l}\text { Duration, } \\
\min \end{array}$} & \multirow{2}{*}{\begin{tabular}{|l} 
Op \\
Stat \\
Code \\
1
\end{tabular}} & \multirow{2}{*}{\begin{tabular}{|l} 
Operational \\
Status
\end{tabular}} & \multirow{2}{*}{\begin{tabular}{|l} 
Operational \\
Status-Comments
\end{tabular}} & \multirow{2}{*}{\begin{tabular}{|l|} 
Track \\
Method
\end{tabular}} & \multirow{2}{*}{\begin{tabular}{|l|} 
Pattern \\
NA
\end{tabular}} & \multicolumn{2}{|c|}{ Field Conditions } & \multirow{2}{*}{\begin{tabular}{|l} 
No. of \\
People
\end{tabular}} \\
\hline & & & & & & & & & & & & & & HOT & DRY & \\
\hline 20030522 & 530 & 1500 & $\begin{array}{l}\text { YUMA } \\
\text { EXTREME }\end{array}$ & 530 & 637 & 1 & 7 & 67 & 1 & $\begin{array}{l}\text { SET-UP/ } \\
\text { MOBILIZATION }\end{array}$ & $\begin{array}{l}\text { SETTING UP } \\
\text { EQUIPMENT }\end{array}$ & NA & NA & HOT & DRY & 3 \\
\hline 20030522 & 530 & 1500 & $\begin{array}{l}\text { YUMA } \\
\text { EXTREME }\end{array}$ & 637 & 642 & 0 & 5 & 5 & 2 & $\begin{array}{l}\text { COLLECTING } \\
\text { DATA }\end{array}$ & $\begin{array}{l}\text { EQUIPMENT WAS } \\
\text { CALIBRATED } \\
\text { USING CAL BALL } \\
\end{array}$ & GPS & NA & HOT & DRY & 3 \\
\hline 20030522 & 530 & 1500 & $\begin{array}{l}\text { YUMA } \\
\text { EXTREME }\end{array}$ & 642 & 745 & 1 & 3 & 63 & 2 & $\begin{array}{l}\text { COLLECTING } \\
\text { DATA }\end{array}$ & $\begin{array}{l}\text { RUNNING YUMA } \\
\text { EXTREME } \\
\text { BIDIRECTIONAL } \\
\text { NORTH/SOUTH }\end{array}$ & GPS & LINEAR & HOT & DRY & 3 \\
\hline 20030522 & 530 & 1500 & $\begin{array}{l}\text { YUMA } \\
\text { EXTREME }\end{array}$ & 745 & 800 & 0 & 15 & 15 & 5 & $\begin{array}{l}\text { DOWNTIME DUE } \\
\text { TO EQUIP } \\
\text { MAINT/CHECK }\end{array}$ & $\begin{array}{l}\text { CHECKING/ } \\
\text { DOWNLOADING } \\
\text { DATA }\end{array}$ & GPS & NA & HOT & DRY & 3 \\
\hline 20030522 & 530 & 1500 & $\begin{array}{l}\text { YUMA } \\
\text { EXTREME }\end{array}$ & 800 & 930 & 1 & 30 & 90 & 2 & $\begin{array}{l}\text { COLLECTING } \\
\text { DATA }\end{array}$ & $\begin{array}{l}\text { RUNNING YUMA } \\
\text { EXTREME } \\
\text { BIDIRECTIONAL } \\
\text { NORTH/SOUTH }\end{array}$ & GPS & LINEAR & HOT & DRY & 3 \\
\hline 20030522 & 530 & 1500 & $\begin{array}{l}\text { YUMA } \\
\text { EXTREME }\end{array}$ & 930 & 935 & 0 & 5 & 5 & 5 & $\begin{array}{l}\text { DOWNTIME DUE } \\
\text { TO EQUIP } \\
\text { MAINT/CHECK }\end{array}$ & $\begin{array}{l}\text { SWAP OUT } \\
\text { BATTERIES }\end{array}$ & NA & NA & HOT & DRY & 3 \\
\hline 20030522 & 530 & 1500 & $\begin{array}{l}\text { YUMA } \\
\text { EXTREME }\end{array}$ & 935 & 950 & 0 & 15 & 15 & 2 & $\begin{array}{l}\text { COLLECTING } \\
\text { DATA }\end{array}$ & $\begin{array}{l}\text { RUNNING YUMA } \\
\text { EXTREME } \\
\text { BIDIRECTIONAL } \\
\text { NORTH/SOUTH }\end{array}$ & GPS & LINEAR & HOT & DRY & 3 \\
\hline 20030522 & 530 & 1500 & $\begin{array}{l}\text { YUMA } \\
\text { EXTREME }\end{array}$ & 950 & 1005 & 0 & 15 & 15 & 5 & $\begin{array}{l}\text { DOWNTIME DUE } \\
\text { TO EQUIP } \\
\text { MAINT/CHECK } \\
\end{array}$ & $\begin{array}{l}\text { CHECKING/ } \\
\text { DOWNLOADING } \\
\text { DATA }\end{array}$ & GPS & NA & HOT & DRY & 3 \\
\hline 20030522 & 530 & 1500 & $\begin{array}{l}\text { YUMA } \\
\text { EXTREME }\end{array}$ & 1005 & 1020 & 0 & 15 & 15 & 3 & BREAK/LUNCH & BREAK & NA & NA & HOT & DRY & 3 \\
\hline 20030522 & 530 & 1500 & $\begin{array}{l}\text { CALIBRATION } \\
\text { PIT }\end{array}$ & 1020 & 1028 & 0 & 8 & 8 & 1 & $\begin{array}{l}\text { SET-UP/ } \\
\text { MOBILIZATION }\end{array}$ & $\begin{array}{l}\text { SET UP OVER } \\
\text { CALIBRATION PIT }\end{array}$ & NA & NA & HOT & DRY & 3 \\
\hline 20030522 & 530 & 1500 & $\begin{array}{l}\text { CALIBRATION } \\
\text { PIT }\end{array}$ & 1028 & 1030 & 0 & 2 & 2 & 2 & $\begin{array}{l}\text { COLLECTING } \\
\text { DATA }\end{array}$ & $\begin{array}{l}\text { EQUIPMENT WAS } \\
\text { CALIBRATED } \\
\text { USING CAL BALL }\end{array}$ & GPS & NA & HOT & DRY & 3 \\
\hline 20030522 & 530 & 1500 & $\begin{array}{l}\text { CALIBRATION } \\
\text { PIT }\end{array}$ & 1030 & 1052 & 0 & 22 & 22 & 2 & $\begin{array}{l}\text { COLLECTING } \\
\text { DATA }\end{array}$ & $\begin{array}{l}\text { RUNNING } \\
\text { SIGNITURE DATA } \\
\text { ON 4OMM MARK II }\end{array}$ & GPS & LINEAR & HOT & DRY & 3 \\
\hline 20030522 & 530 & 1500 & $\begin{array}{l}\text { CALIBRATION } \\
\text { PIT }\end{array}$ & 1052 & 1105 & 0 & 13 & 13 & 2 & $\begin{array}{l}\text { COLLECTING } \\
\text { DATA }\end{array}$ & $\begin{array}{l}\text { RUNNING } \\
\text { SIGNITURE DATA } \\
\text { ON 57MM }\end{array}$ & GPS & LINEAR & HOT & DRY & 3 \\
\hline 20030522 & 530 & 1500 & $\begin{array}{l}\text { CALIBRATION } \\
\text { PIT }\end{array}$ & 1105 & 1128 & 0 & 23 & 23 & 2 & $\begin{array}{l}\text { COLLECTING } \\
\text { DATA }\end{array}$ & $\begin{array}{l}\text { RUNNING } \\
\text { SIGNITURE DATA } \\
\text { ON 6OMM }\end{array}$ & GPS & LINEAR & HOT & DRY & 3 \\
\hline 20030522 & 530 & 1500 & $\begin{array}{l}\text { CALIBRATION } \\
\text { PIT }\end{array}$ & 1128 & 1138 & 0 & 10 & 10 & 3 & BREAK/LUNCH & BREAK & NA & NA & HOT & DRY & 3 \\
\hline
\end{tabular}




\begin{tabular}{|c|c|c|c|c|c|c|c|c|c|c|c|c|c|c|c|c|}
\hline \multirow{2}{*}{\begin{tabular}{|l} 
Date \\
20030522
\end{tabular}} & \multirow{2}{*}{$\begin{array}{l}\text { Start- } \\
\text { Time } \\
530\end{array}$} & \multirow{2}{*}{\begin{tabular}{|l|} 
Stop- \\
Time \\
1500 \\
\end{tabular}} & \multirow{2}{*}{$\begin{array}{l}\text { Area Tested } \\
\text { CALIBRATION } \\
\text { PIT }\end{array}$} & \multirow{2}{*}{\begin{tabular}{|l|}
$\begin{array}{l}\text { Status } \\
\text { Start } \\
\text { Time }\end{array}$ \\
1138 \\
\end{tabular}} & \multirow{2}{*}{\begin{tabular}{|l|}
$\begin{array}{l}\text { Status } \\
\text { Stop } \\
\text { Time }\end{array}$ \\
1149 \\
\end{tabular}} & \multirow{2}{*}{$\begin{array}{l}\text { hr } \\
0\end{array}$} & \multirow{2}{*}{\begin{tabular}{|l|}
$\min$ \\
11 \\
\end{tabular}} & \multirow{2}{*}{$\begin{array}{l}\text { Duration, } \\
\min \end{array}$} & \multirow{2}{*}{$\begin{array}{l}\text { Op } \\
\text { Stat } \\
\text { Code } \\
5\end{array}$} & \multirow{2}{*}{\begin{tabular}{|l} 
Operational \\
Status \\
DOWNTIME DUE \\
TO EQUIP \\
MAINT/CHECK
\end{tabular}} & \multirow{2}{*}{\begin{tabular}{|l} 
Operational \\
Status-Comments \\
CHECKING/ \\
DOWNLOADING \\
DATA
\end{tabular}} & \multirow{2}{*}{\begin{tabular}{|l|} 
Track \\
Method
\end{tabular}} & \multirow{2}{*}{\begin{tabular}{|l|} 
Pattern \\
NA
\end{tabular}} & \multicolumn{2}{|c|}{ Field Conditions } & \multirow{2}{*}{\begin{tabular}{|l} 
No. of \\
People
\end{tabular}} \\
\hline & & & & & & & & & & & & & & HOT & DRY & \\
\hline 20030522 & 530 & 1500 & $\begin{array}{l}\text { CALIBRATION } \\
\text { PIT }\end{array}$ & 1149 & 1240 & 0 & 51 & 51 & 3 & BREAK/LUNCH & $\mathrm{LUNCH}$ & NA & NA & HOT & DRY & 3 \\
\hline 20030522 & 530 & 1500 & $\begin{array}{l}\text { CALIBRATION } \\
\text { PIT }\end{array}$ & 1240 & 1243 & 0 & 3 & 3 & 2 & $\begin{array}{l}\text { COLLECTING } \\
\text { DATA }\end{array}$ & $\begin{array}{l}\text { EQUIPMENT WAS } \\
\text { CALIBRATED } \\
\text { USING CAL BALL }\end{array}$ & GPS & NA & HOT & DRY & 3 \\
\hline 20030522 & 530 & 1500 & $\begin{array}{l}\text { CALIBRATION } \\
\text { PIT }\end{array}$ & 1243 & 1255 & 0 & 12 & 12 & 2 & $\begin{array}{l}\text { COLLECTING } \\
\text { DATA }\end{array}$ & $\begin{array}{l}\text { RUNNING } \\
\text { SIGNITURE DATA } \\
\text { ON ROCKEYE } \\
\text { MK118 }\end{array}$ & GPS & LINEAR & HOT & DRY & 3 \\
\hline 20030522 & 530 & 1500 & $\begin{array}{l}\text { CALIBRATION } \\
\text { PIT }\end{array}$ & 1255 & 1320 & 0 & 25 & 25 & 2 & $\begin{array}{l}\text { COLLECTING } \\
\text { DATA }\end{array}$ & $\begin{array}{l}\text { RUNNING } \\
\text { SIGNITURE DATA } \\
\text { ON } 2.75 \text { ROCKET }\end{array}$ & GPS & LINEAR & HOT & DRY & 3 \\
\hline 20030522 & 530 & 1500 & $\begin{array}{l}\text { CALIBRATION } \\
\text { PIT }\end{array}$ & 1320 & 1347 & 0 & 27 & 27 & 2 & $\begin{array}{l}\text { COLLECTING } \\
\text { DATA }\end{array}$ & $\begin{array}{l}\text { RUNNING } \\
\text { SIGNITURE DATA } \\
\text { ON } 105 \\
\text { STANDARD }\end{array}$ & GPS & LINEAR & HOT & DRY & 3 \\
\hline 20030522 & 530 & 1500 & $\begin{array}{l}\text { CALIBRATION } \\
\text { PIT }\end{array}$ & 1347 & 1412 & 0 & 25 & 25 & 2 & $\begin{array}{l}\text { COLLECTING } \\
\text { DATA }\end{array}$ & $\begin{array}{l}\text { RUNNING } \\
\text { SIGNITURE DATA } \\
\text { ON 155MM }\end{array}$ & GPS & LINEAR & HOT & DRY & 3 \\
\hline 20030522 & 530 & 1500 & $\begin{array}{l}\text { CALIBRATION } \\
\text { PIT }\end{array}$ & 1412 & 1414 & 0 & 2 & 2 & 2 & $\begin{array}{l}\text { COLLECTING } \\
\text { DATA }\end{array}$ & $\begin{array}{l}\text { EQUIPMENT WAS } \\
\text { CALIBRATED } \\
\text { USING CAL BALL }\end{array}$ & GPS & NA & HOT & DRY & 3 \\
\hline 20030522 & 530 & 1500 & $\begin{array}{l}\text { CALIBRATION } \\
\text { PIT }\end{array}$ & 1414 & 1500 & 0 & 46 & 46 & 7 & DEMOBILIZATION & END OF TEST & NA & NA & HOT & DRY & 3 \\
\hline
\end{tabular}




\title{
Appendix C: Soil Analysis
}

\author{
http:// aec.army.mil/ usaec/ technology/ uxo-soilanalysis.pdf
}

Table C1. Laboratory tests performed on soil samples.

\begin{tabular}{|c|c|c|c|c|c|}
\hline Sample & \begin{tabular}{|l} 
Water \\
Content
\end{tabular} & Sieve/Hydrometer & \begin{tabular}{|l} 
Magnetic \\
Susceptibility
\end{tabular} & \begin{tabular}{|l|} 
Dielectric \\
Permittivity
\end{tabular} & $\begin{array}{l}\text { X-Ray } \\
\text { Diffraction }\end{array}$ \\
\hline Y-CA-SS1 to Y-CA-SS3 & $x$ & $x$ & $x$ & & \\
\hline Y-EA-SS1 to Y-EA-SS2 & $x$ & $x$ & $x$ & & \\
\hline Y-MA-SS1 to Y-MA-SS2 & $x$ & $x$ & $x$ & & \\
\hline Y-OR-SS1 to Y-OR-SS3 & $x$ & $x$ & $x$ & & \\
\hline 13 Soil cores & & & $x$ & & \\
\hline $\begin{array}{l}\text { Y-BL-1* } \\
\text { Y-CA-1* } \\
\text { Y-EA-1*, Y-EA-2* } \\
\text { Y-MA-1*, Y-MA-2* } \\
\text { Y-OR-1 to Y-OR-7* } \\
0.05 \mathrm{~m}\end{array}$ & $\mathrm{X}$ & $\mathrm{X}$ & $x$ & $X^{*}$ & \\
\hline $0.25 \mathrm{~m}$ & $x$ & $x$ & $x$ & & \\
\hline $0.50 \mathrm{~m}$ & $x$ & $x$ & $x$ & $x$ & \\
\hline $1.00 \mathrm{~m}$ & $x$ & $x$ & $x$ & $x$ & \\
\hline $1.50 \mathrm{~m}$ & $x$ & $x$ & $x$ & & \\
\hline $2.00 \mathrm{~m}$ & $x$ & $x$ & $x$ & $x$ & \\
\hline $2.50 \mathrm{~m}$ & $x$ & $x$ & $x$ & & \\
\hline $3.00 \mathrm{~m}$ & $x$ & $x$ & $x$ & $x$ & \\
\hline Y-OR-3 2.00m & & & & & $x$ \\
\hline Y-OR-5 1.00m & & & & & $x$ \\
\hline Y-OR-5 2.50m & & & & & $x$ \\
\hline Y-OR-5 3.00m & & & & & $x$ \\
\hline \multicolumn{6}{|c|}{$\begin{array}{l}\text { * Exceptions to laboratory Tests } \\
\text { Y-BL-1: no dielectric permittivity measurement at } 3.00 \mathrm{~m} \text { (insufficient soil recovery) } \\
\text { Y-CA-1: no dielectric permittivity measurement at } 1.00 \mathrm{~m} \text { (insufficient soil recovery) } \\
\text { Y-EA-1: no water content at } 0.5 \mathrm{~m} \text {; no mag. susceptibility at } 0.25 \mathrm{~m} \text {; no dielectric perm. at } 0.5 \mathrm{~m} \\
\text { Y-EA-2: no soil recovery above } 1.00 \mathrm{~m} \\
\text { Y-OR-2: end of push at } 2.00 \mathrm{~m} \\
\text { Y-OR-3: no measurements at } 0.25,0.50 \mathrm{~m} \text { (insufficient soil recovery) } \\
\text { Y-EA-2, Y-MA-2, Y-OR-1, Y-OR-4, Y-OR-5, Y-OR-6: no 5-cm dielectric permittivity measurement. }\end{array}$} \\
\hline
\end{tabular}


Table C2. Summary of sieve and hydrometer analysis, surface samples.

\begin{tabular}{|c|c|c|c|c|c|c|c|c|}
\hline Sample & $\begin{array}{l}\text { Depth } \\
\text { (m) }\end{array}$ & \begin{tabular}{|l|} 
Visual \\
Classification
\end{tabular} & Color & $\begin{array}{l}\% \\
\text { Gravel }\end{array}$ & \%Sand & \%Fines & $\begin{array}{l}\text { Specific Gravity } \\
\text { of Solids }\end{array}$ & $\begin{array}{l}\% \text { Water } \\
\text { Content }\end{array}$ \\
\hline \multicolumn{9}{|c|}{ Calibration } \\
\hline Y-CA-551 & Surface & Gravelly silty sand & Brown & 41.7 & 41.8 & 16.6 & 2.67 & 0.6 \\
\hline Y-CA-552 & Surface & Gravelly clay sand & Brown & 28.5 & 41.1 & 30.4 & 2.67 & 1.0 \\
\hline \multicolumn{9}{|c|}{ Blind } \\
\hline Y-CA-553 & Surface & Gravelly clay sand & Brown & 33.7 & 38.5 & 27.7 & 2.67 & 0.8 \\
\hline \multicolumn{9}{|c|}{ Extreme } \\
\hline Y-EA-551 & Surface & Sandy silty gravel & Brown & 59.9 & 30.1 & 10.1 & 2.67 & 0.5 \\
\hline Y-EA-552 & Surface & Gravelly silty sand & Brown & 32.4 & 52.4 & 15.2 & 2.67 & 0.5 \\
\hline \multicolumn{9}{|c|}{ Mogul } \\
\hline Y-MA-551 & Surface & Gravelly silty sand & Brown & 24.1 & 41.0 & 35.0 & 2.67 & 0.5 \\
\hline Y-MA-552 & Surface & Sandy silty gravel & Brown & 41.5 & 26.0 & 32.5 & 2.67 & 0.5 \\
\hline \multicolumn{9}{|c|}{ Open Range } \\
\hline YY-CR-551 & Surface & Gravelly silty sand & Brown & 40.2 & 48.2 & 11.6 & 2.67 & 0.5 \\
\hline YY-CR-552 & Surface & Gravelly silty sand & Brown & 36.2 & 47.6 & 17.1 & 2.67 & 0.6 \\
\hline YY-CR-553 & Surface & Gravelly silty sand & Brown & 15.5 & 58.0 & 26.5 & 2.67 & 0.6 \\
\hline YY-CR-554 & Surface & Gravelly silty sand & Brown & 17.3 & 40.5 & 42.3 & 2.67 & 0.9 \\
\hline YY-CR-555 & Surface & Sandy silty gravel & Brown & 44.8 & 24.6 & 30.6 & 2.67 & 0.9 \\
\hline YY-CR-556 & Surface & Gravelly silty sand & Brown & 26.5 & 38.7 & 33.8 & 2.67 & 0.7 \\
\hline YY-CR-557 & Surface & Gravelly clay sand & Brown & 27.1 & 46.5 & 26.4 & 2.67 & 0.7 \\
\hline YY-CR-558 & Surface & Gravelly silty sand & Brown & 27.0 & 31.6 & 41.5 & 2.67 & 0.9 \\
\hline
\end{tabular}




\title{
Appendix D: Definitions from ATC Web site
}

\author{
Anomaly \\ Location of a system response deemed to warrant further \\ investigation by the demonstrator for consideration as an emplaced \\ ordnance item. \\ Azimuth \\ Positive clockwise direction of the ordnance nose from magnetic \\ North. \\ $\mathrm{BA}^{\text {dise }}$ \\ A discrimination-stage location outside $R_{\text {hulo }}$ of any emplaced \\ ordnance or emplaced clutter item. \\ $\mathrm{BAR}^{\text {dsc }}$ \\ $=\left(\#\right.$ of $\left.\mathrm{BA}^{\mathrm{d} * 0}\right) /$ (test area) . \\ $\mathrm{BA}^{\mathrm{res}}$ \\ An anomaly from the response stage outside $R_{\text {hal }}$ of any emplaced \\ ordnance or emplaced clutter item. \\ $\mathrm{BAR}^{\text {res }}$ \\ $=\left(\#\right.$ of $\left.B A^{\text {ret }}\right) /($ test area $)$. \\ Blind Test Grid \\ A matrix of squares. Center of each grid block may be a target, a \\ piece of clutter, or nothing to test demonstrator detection system \\ performance. \\ Calibration Lane \\ Contains targets from the standardized target list at 7 primary \\ orientations to allow the demonstrator to develop a library on his \\ detection system performance against known targets and location. \\ Clutter \\ Clutter items may include fragments of military munitions which \\ have functioned as designed or were recovered from areas where \\ munitions have been intentionally destroyed and have no \\ explosive, pyrotechnic or chemical filler; steel; aluminum; \\ magnetic rock; or copper. \\ Degaussing \\ Removing any remnant magnetic moments from ordnance targets. \\ Demonstrator \\ Vendor, user, developer of UXO detection and discrimination \\ technologies. \\ Detection \\ An anomaly location that is within $R_{\text {halo }}$ of an emplaced ordnance \\ item. \\ Dip \\ Angle of inclination; Nose up (+), Nose down (-). \\ Discrimination \\ The application of a signal processing algorithm or human \\ judgment to response-stage data that discriminates ordnance from \\ clutter.
}


Discrimination Stage

Efficiency (E)

Emplaced Clutter

Emplaced Ordnance

FAR

FAR

$\mathrm{fp}^{\mathrm{d}} \mathrm{is}$

$\mathrm{fp}^{\mathrm{res}}$

Large Ordnance

Medium Ordnance
The ability to conrectly identify ordnance as such, and to reject clutter. For the same locations as in the RESPONSE STAGE anomaly column, the DISCRIMINATION STAGE column contains the output of the algorithms applied in the discriminationstage processing. This column is prioritized based on the determination that an anomaly location is likely to contain ordnance. Thus, higher output values are indicative of higher confidence that an ordnance item is present at the specified location. For electronic signal processing, priority ranking is based on algorithm output. For other systems, priority ranking is based on human judgment. The demonstrator also selects the threshold that provides optimum system performance, (i.e., that retains all the detected ordnance and rejects the maximum amount of clutter).

$=\mathrm{P}_{\text {des }}{ }^{\text {diso }}\left(\mathrm{t}^{\mathrm{dis}}\right) / \mathrm{P}_{\text {det }}{ }^{\text {res }}\left(\mathrm{t}_{\min }{ }^{\text {res }}\right) ; \mathrm{Measures}$ (at a threshold of interest), the degree to which the maximum theoretical detection performance of the sensor system (as determined by the response stage $\left.t_{\min }\right)$ is preserved after application of discrimination techniques. Efficiency is a number between 0 and 1 . An efficiency of 1 implies that all of the ordnance initially detected in the response stage was retained at the specified threshold in the discrimination stage, $t^{\text {dise }}$.

A clutter item (i.e., nonordnance item) buried by the government at a specified location in the test site.

An inert ordnance item buried by the government at a specified location in the test site.

False identification of target in a empty grid cell.

$=\left(\#\right.$ of $\left.\mathrm{BA}^{\mathrm{res}}\right) /(\#$ of opportunities $)$.

A discrimination-stage location within $R_{\text {tulo }}$ of an emplaced clutter item.

An anomaly location that is within $R_{\text {halo }}$ of an emplaced clutter item.

Caliber of ordnance greater than 81-mm (includes 105-mm HEAT, $105-\mathrm{mm}$ projectile, $155-\mathrm{mm}$ projectile, $500-1 \mathrm{~b}$ bomb).

Caliber of ordnance greater than 40-mm and less than or equal to 81-mm (includes 57-mm projectile, 60-mm mortar, 2.75-inch Rocket, MK 118 Rockeye, 81-mm mortar). 
NAD83 Datum

Open Field Site

$\mathrm{P}_{\mathrm{ba}}{ }^{\mathrm{div}}$

$\mathrm{P}_{\text {det }}{ }^{\mathrm{asc}}$

$\underline{P}_{\text {dit }}^{\text {nes }}$

$\mathrm{P}_{\mathrm{f}_{\mathrm{p}}}^{\mathrm{res}}$

$R_{B A}$

$\mathbf{R}_{\mathrm{fp}}$

$\mathbf{R}_{\text {hato }}$

Raw Sensor Data
Expressed as an Easting/Northing UTM number.

Minimum 4 hectares site with a myriad of clutter, range simulations, and targets to test demonstrator detection system performance under real field-type conditions.

$=\left(\#\right.$ of $\left.\mathrm{BA}^{\mathrm{das}}\right) /(\#$ of empty grid locations $)$.

$=(\#$ of discrimination-stage detections $) /(\#$ of emplaced ordnance in the test site).

= (\# of response-stage detections)/(\# of emplaced ordnance in the test site).

= (\# of response-stage false positives $) /(\#$ of emplaced clutter items).

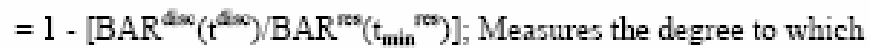
the discrimination stage correctly rejects background alarms initially detected in the response stage. The rejection rate is a number between 0 and 1 . A rejection rate of 1 implies that all background alarms initially detected in the response stage were rejected at the specified threshold in the discrimination stage.

$=1-\left[\mathrm{P}_{\mathrm{f}_{\mathrm{p}}}^{\text {diso }}\left(\mathrm{t}^{\mathrm{dis}}\right) \mathrm{P}_{\mathrm{fp}}{ }^{\mathrm{rss}}\left(\mathrm{t}_{\min }{ }^{\mathrm{res}}\right)\right]$; Measures (at a threshold of interest), the degree to which the sensor system's false positive performance is improved over the maximum false positive performance (as determined by the response stage tmin). The rejection rate is a number between 0 and 1 . A rejection rate of 1 implies that all emplaced clutter initially detected in the response stage were correctly rejected at the specified threshold in the discrimination stage.

A predetermined radius about the center of the periphery of an emplaced item (clutter or ordnance) within which a location identified by the demonstrator as being of interest is considered to be a response from that item. If multiple declarations lie within $R_{\text {haio }}$ of any item (clutter or ordnance), the declaration with the highest signal output within the $\mathrm{R}_{\text {hwo }}$ is utilized.

Preprocessed or minimally processed data for each grid square or open field area. 
Response Stage

ROC Curve

Small Ordnance

Standardized Site

Standardized Target

Threshold

Target Repository
The ability of the demonstrator's system to detect emplaced targets without regard to ability to discriminate ordnance from other anomalies. The RESPONSE STAGE provides the location and signal strength of all anomalies deemed sufficient to warrant further investigation and/or processing as potential emplaced ordnance items. This list is generated with minimal processing (e.g., this list will include all signals above the system noise threshold). As such, it represents the most inclusive list of anomalies.

Receiver Operating Characteristic curve provides the only useful and valid means of comparing performance among sensor/algorithm combinations and for determining the efficacy of algorithm or technology advancements.

Caliber of ordnance less than or equal to 40-mm (includes 20-mm projectile, 40-mm projectile, submunitions BLU-26, BDU-28, and $\mathrm{M} 42$ ).

Made up of three areas - Calibration Lanes/Ground Test Pit, a Blind Test Grid, and an Open Field Site designed to test the demonstrator detection systems under various test parameters.

A military munition which contains no energetic material. These items pose no imminent threat. However, will remain under the control of the Standardized UXO Technology Demonstration Site On-Site Project Manager as issued by the ATC Project Manager.

The limit, set on a system's discrimination stage, which defines the difference between what is considered to be ordnance and what is considered nonordnance. Only those signals that exceed (or fall below, depending on the signal strength polarity) the threshold are considered to result from ordnance.

Located at Aberdeen Proving Ground, MD. Managed by the ATC Target Repository Standardized UXO Technology Demonstration Site Program Manager. Thirteen types of standardized targets are available for loan. 
Unexploded Ordnance (UXO)
A military munition that contains explosive or pyrotechnic charge and has been primed, fuzed, armed or otherwise prepared for action and which has been fired, placed, dropped, launched or projected, and remains unexploded by design or malfunction. An item of explosive ordnance which has failed to function as designed or has been abandoned, discarded or improperly disposed of and is still capable of functioning, causing damage to persomel or material. These can be, but are not limited to high-explosive warheads, rocket motors, practice munitions with spotting charges, torpedoes, artillery and mortar ammunition, grenades, incendiary munitions, electro-explosive devices and propellant-actuated devices. Fuzes with live explosive boosters or detonators are classified as UXO. All UXO are potentially dangerous and cannot be released for public use without being rendered safe (neutralized, vented, detonated, decontaminated or demilitarized). 


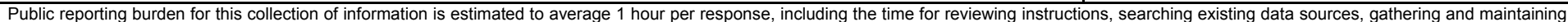

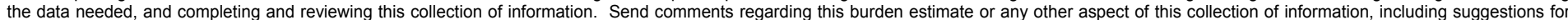

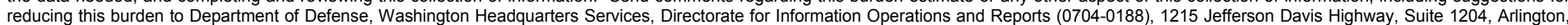

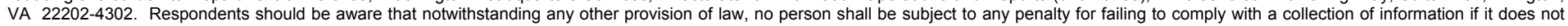
display a currently valid OMB control number. PLEASE DO NOT RETURN YOUR FORM TO THE ABOVE ADDRESS.

\begin{tabular}{l|c}
$\begin{array}{l}\text { 1. REPORT DATE }(D D-M M-Y Y Y Y) \\
\text { November } 2007\end{array}$ & $\begin{array}{c}\text { 2. REPORT TYPE } \\
\text { Final report }\end{array}$ \\
\hline
\end{tabular}

4. TITLE AND SUBTITLE

Yuma Proving Ground GEM-3-E Data Collection

3. DATES COVERED (From - To)

5a. CONTRACT NUMBER

5b. GRANT NUMBER

5c. PROGRAM ELEMENT NUMBER

6. AUTHOR(S)

5d. PROJECT NUMBER

Hollis H. "Jay" Bennett, Jr., Tere A. DeMoss, Morris P. Fields,

Ricky A. Goodson, Charles D. Hahn, and John Cliff Morgan

5e. TASK NUMBER

5f. WORK UNIT NUMBER

7. PERFORMING ORGANIZATION NAME(S) AND ADDRESS(ES)

8. PERFORMING ORGANIZATION REPORT NUMBER

Environmental Laboratory

U.S. Army Engineer Research and Development Center

ERDC/EL TR-07-28

3909 Halls Ferry Road

Vicksburg, MS 39180-6199

9. SPONSORING / MONITORING AGENCY NAME(S) AND ADDRESS(ES)

U.S. Army Corps of Engineers

Washington, DC 20314-1000

10. SPONSOR/MONITOR'S ACRONYM(S)

11. SPONSOR/MONITOR'S REPORT NUMBER(S)

\section{DISTRIBUTION / AVAILABILITY STATEMENT}

Approved for public release; distribution is unlimited.

\section{SUPPLEMENTARY NOTES}

\section{ABSTRACT}

This report documents the performance and operational capabilities of the GEM-3 system for the Advanced UXO Detection/ Discrimination Technology Demonstration at the U.S. Army Yuma Proving Ground (YPG), Yuma, AZ. The data collection effort was conducted under the Department of the Army Research and Development DOBE4 (BA4) Technical Demonstration Program. Data analysis was conducted under the Department of the Army Research and Development DOE3 (BA3) Program. The objective was to evaluate the enhancements made to the GEM-3 system. Post-demonstration analysis focused on the functionality of the sensor system, the evaluation of the noise level of the data collected, improvements in target detection and discrimination, and positioning accuracy of the system. The stability of the system was evaluated through histograms and statistical analysis of data collected during the technology demonstration. Based on findings of the characteristics of the collected data and initial work performed on target detection and discrimination, target detection and discrimination techniques were applied and evaluated.

\section{SUBJECT TERMS}

See reverse.

16. SECURITY CLASSIFICATION OF:

a. REPORT

UNCLASSIFIED

b. ABSTRACT
UNCLASSIFIED

c. THIS PAGE

UNCLASSIFIED

\begin{tabular}{l|c|}
$\begin{array}{l}\text { 17. LIMITATION } \\
\text { OF ABSTRACT }\end{array}$ & $\begin{array}{c}\text { 18. NUMBER } \\
\text { OF PAGES }\end{array}$ \\
\cline { 2 - 2 } & 68
\end{tabular}

19a. NAME OF RESPONSIBLE PERSON

19b. TELEPHONE NUMBER (include area code) 


\section{SUBJECT TERMS}

Aberdeen Testing Center (ATC)

Electromagnetic induction (EMI)

EMI sensor

Frequency domain electromagnetic (FDEM)

Geophex, Ltd.

Unexploded ordnance (UXO)

YPG Standardized UXO Technology Demonstration Site

Yuma Proving Ground (YPG) 